DEPARTMENT OF THE INTERIOR

UNITEED STATES GEOLOGICAL SURVEY

GEORGE OTIS SMITH, DIRECTOR

BULLETIN 420

ECONOMIC GEOLOGY

OF THE

\section{FELDSPAR DEPOSITS OF THE UNITED STATES}

BY

EDSON S. BASTIN

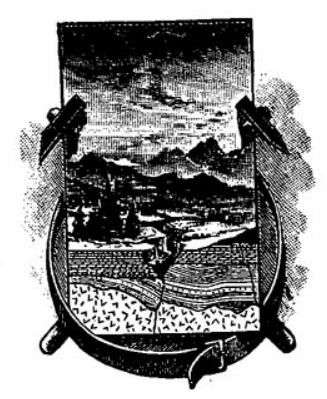

WASHIN GTON

GOVERNMENT PRINTING OFFICE

1910 
TEXAS TECH UNIVERSITY

3 1295013470199 



\section{CONTENTS.}

Introduction $\quad$ Page.

Chemical and physical characters................................. 5

Potash-soda feldspars. ............................................ 5

Lime-soda feldspars, or plagioclases............................ 7

Origin and geologic occurrence................................... 10

Minerals of the feldspar deposits................................. 11

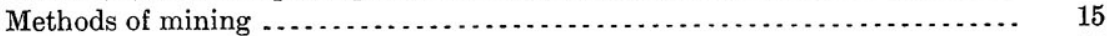

Commercial availability of deposits............................. 16

Methods of milling................................................ 18

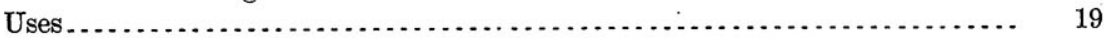

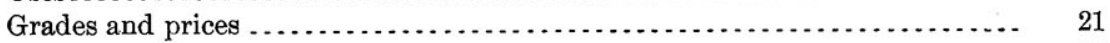

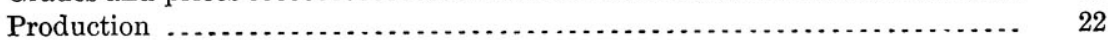

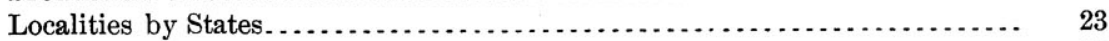

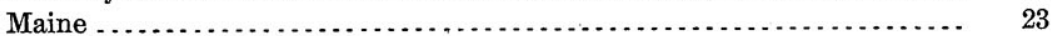

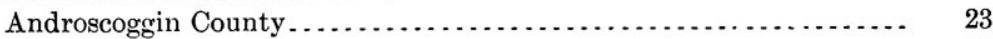

Auburn .................................................. 23

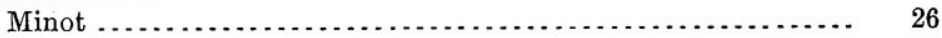

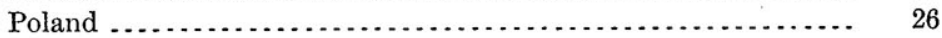

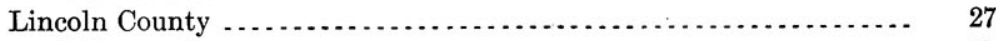

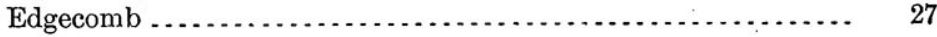

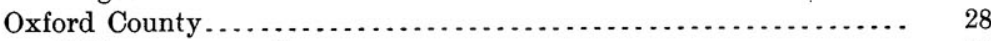

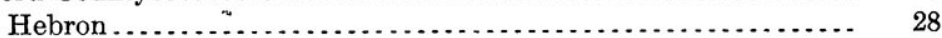

Sagadahoc County ............................................. 31

Georgetown........................................... 31

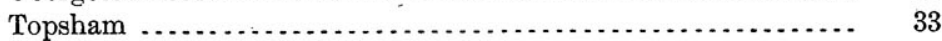

Massachusetts..................................................... 41

Connecticut..................................................... 41

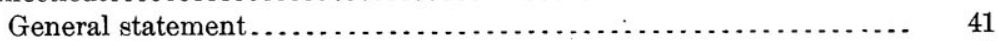

Hartford County ...................................... 42

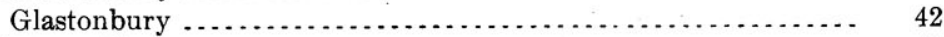

Middlesex County ..................................... 47

Chatham .................................................... 47

Haddam ............................................. 48

Middletown .......................................... 49

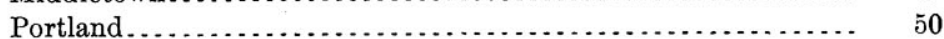

New Haven County ......................................... 53

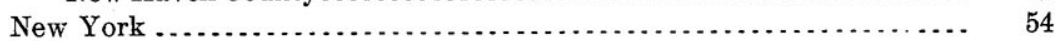

Essex County .................................................. 54

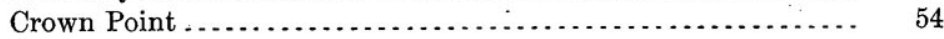

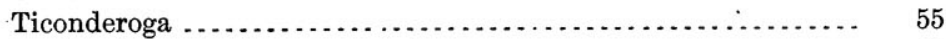

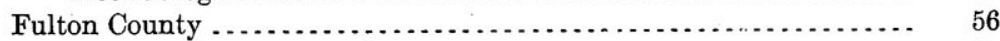

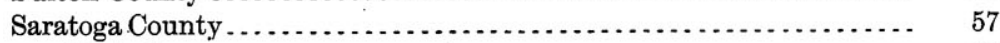

Corinth.................................................... 57

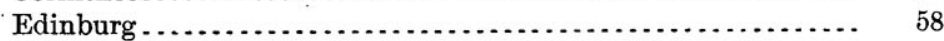


Localities by States-Continued. Page.

New York-Continued.

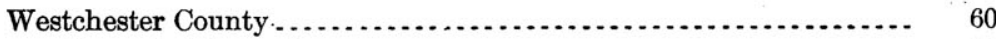

General statement....................................... 60

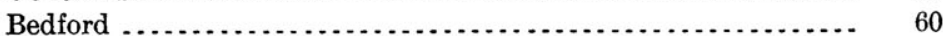

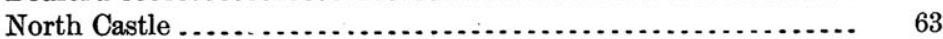

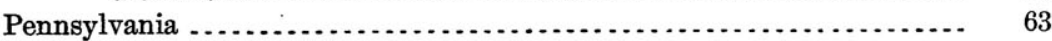

General statement................................................... 63

Chester County .................................................... 64

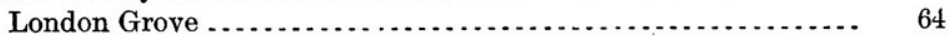

New Garden .............................................. 66

Newlin .................................................... 67

West Caln .................................................... 67

West Nottingham ...................................... 68

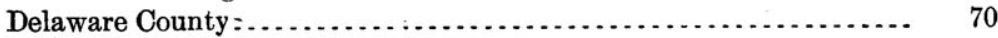

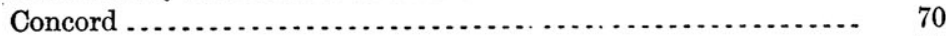

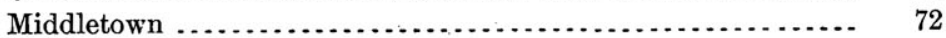

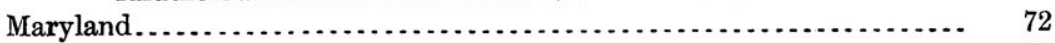

Baltimore County ........................................... 72

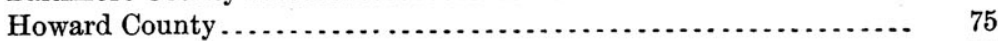

Cecil County ..................................................... 76

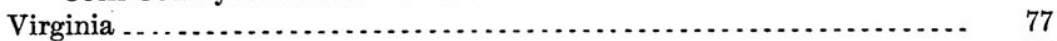

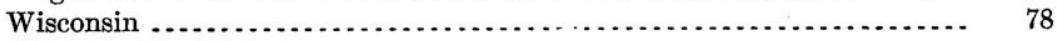

Minnesota ....................................................... 78

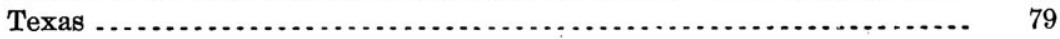

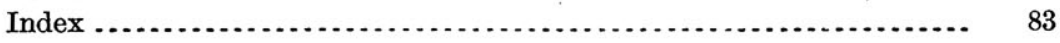

\section{ILLUSTRATIONS.}

Plate I. Microphotograph of thin section of feldspar from quarry of Goldings Sons Company, Georgetown, Maine.

II. $A$, Highly inclined dike of pegmatite in schists at Pemaquid Point, Maine; $B$, Flat-lying or sill-like dike in pegmatite in bed of Androscoggin River, Auburn-Lewiston, Maine..................

III. Intergrowths of feldspar and quartz...........................

IV. Preliminary geologic map of portions of Maine, showing location of feldspar quarries and mills.

V. $A$, Crystal of microcline feldspar in Roaring Creek feldspar quarry, Connecticut; $B$, Portion of G. D. Willes feldspar quarry, Topsham, Maine.

VI. Preliminary geologic map of a portion of Connecticut, showing location of feldspar quarries and mills.

VII. $A$, Vertical pegmatite dike intruded along fracture plane in granite gneiss, East Glastonbury, Conn.; $B$, Quartz dike cutting pegmatite at Howe quarry, South Glastonbury, Conn

VIII. Preliminary geologic map of southeastern Pennsylvania and adjacent parts of Delaware and Maryland, showing locations of feldspar quarries and mills, $, \ldots, \ldots, \ldots, \ldots, \ldots, \ldots, \ldots, \ldots, \ldots, \ldots, \ldots$ 


\title{
ECONOMIC GEOLOGY OF THE FELDSPAR DEPOSITS OF THE UNITED STATES.
}

\author{
By Edson S. Bastin.
}

\section{INTRODUCTION.}

The present bulletin -brings together in a single volume all available practical information concerning the commercial feldspar deposits of the United States. Scientific problems are discussed only so far as they are of commercial importance or so far as the discussion may contribute to a general understanding of the deposits.

The feldspar localities of Maine were visited by the writer in the summer of 1906 , the work being authorized by the United States Geological Survey in cooperation with the Maine State Survey Commission. Those of New York, Connecticut, Pennsylvania, and Maryland were visited at various times from 1906 to 1909 under the auspices of the United States Geological Survey.

\section{CHEMICAL AND PHYSICAL CHARACTERS.}

The feldspars are compounds of alumina and silica with one or more of the bases potash, soda, and lime; rarely barium is present. They fall into two principal groups, the potash-soda feldspars and the limesoda feldspars, both of which may be present in the same deposit or even intergrown in the same crystal.

\section{POTASH-SODA FELDSPARS.}

The principal representatives of the potash-soda feldspar group are orthoclase and microcline, both of which have the composition $\mathrm{KAISi}_{3} \mathrm{O}_{8}$ or $\mathrm{K}_{2} \mathrm{O} \cdot \mathrm{Al}_{2} \mathrm{O}_{3} \cdot 6 \mathrm{SiO}_{2}$. These two varieties have also the same crystal form and are similar in most of their physical properties. For commercial purposes they may be regarded as identical, since they can not be distinguished from each other with the unaided eye and are often associated in the same crystal. The theoretical percentage composition of pure orthoclase or microcline is as follows: Silica $\left(\mathrm{SiO}_{2}\right), 64.7$ per cent; alumina $\left(\mathrm{Al}_{2} \mathrm{O}_{3}\right), 18.4$ per cent, and potash $\left(\mathrm{K}_{2} \mathrm{O}\right), 16.9$ per cent. Soda may partly or completely replace potash in these feldspars. If it is more abundant than the potash the feldspar is called anorthoclase. 
The feldspars of the potash-soda group mined in the United States are mostly pale flesh colored to nearly white, though the rock from Bedford, N. Y., is reddish and that from near Batchellerville, N. Y., is a pearl gray. The potash spars from Norway and from Bedford, Ontario, are reddish in color. The cause of the reddish color. is not definitely known, but in some feldspars it seems to be due to the presence of small quantities of finely divided iron oxide. The percentage of iron oxide is smaller, however, in many pink feldspars than in those of lighter color. All the pink spars burn perfectly white, and if the color is due to the iron, the content is too small to be in the least detrimental in pottery manufacture. Fresh feldspar is so hard that only with difficulty can it be scratched with a knife blade.

As found in the quarries, the potash-soda feldspars seldom show true crystal faces, but when undecomposed break readily into angular pieces, bounded in part by smooth cleavage faces. There are three directions of cleavage, intersecting at definite angles, which are practically identical for orthoclase and microcline, and change only slightly with an increase in the soda content. Only two of the cleavages are well defined, and these invariably intersect approximately at right angles. Both of these principal cleavage surfaces show a high luster, comparable to that exhibited by a plate of glass, though one cleavage face is a trifle less brilliant than the other. The hardness and the two lustrous cleavage planes intersecting at an angle of $90^{\circ}$ are usually sufficient to identify the mineral as belonging to the gfoup of potashsoda feldspars.

Recent experiments have shown that the potash-rich feldspars do not have a definite melting point-as do metals, for example. Fusion tests made on finely powdered microcline in the geological laboratory of the Carnegie Institution ${ }^{a}$ showed that at $1,000^{\circ} \mathrm{C}$. traces of sintering were evident; at $1,075^{\circ}$ the powder had formed a solid cake; at $1,150^{\circ}$ this cake had softened somewhat, and at $1,300^{\circ} \mathrm{C}$. it had become a viscous liquid, which could be drawn out into glassy threads. In most of the determinations complete fusion has taken place in the dry state at temperatures below Seger cone No. 9, which fuses at about $1,310^{\circ} \mathrm{C}$., or $2,390^{\circ} \mathrm{F}$.

The great bulk of the feldspar quarried in the eastern United States and in Canada belongs to the class described above, being orthoclase or microcline or an intergrowth of these two. In most quarries this is associated with minor quantities of soda feldspar-albite or oligoclase (see below) - occurring either in separate crystals or delicately intergrown with the potash feldspar, as shown in Plate I. The presence of the soda spar renders the ground product slightly more fusible. The specific gravity of orthoclase and microcline varies from 2.54 to 2.56 .

$a$ Day, A. L., and Allen, E. T., The isomorphism and thermal properties of the feldspars: Publ. No. 31 Carnegie Inst. of Washington, 1905, pp. 13-75; also Am. Jour. Sci., 4th ser., vol. 19, pp. 93-142, 1905. 


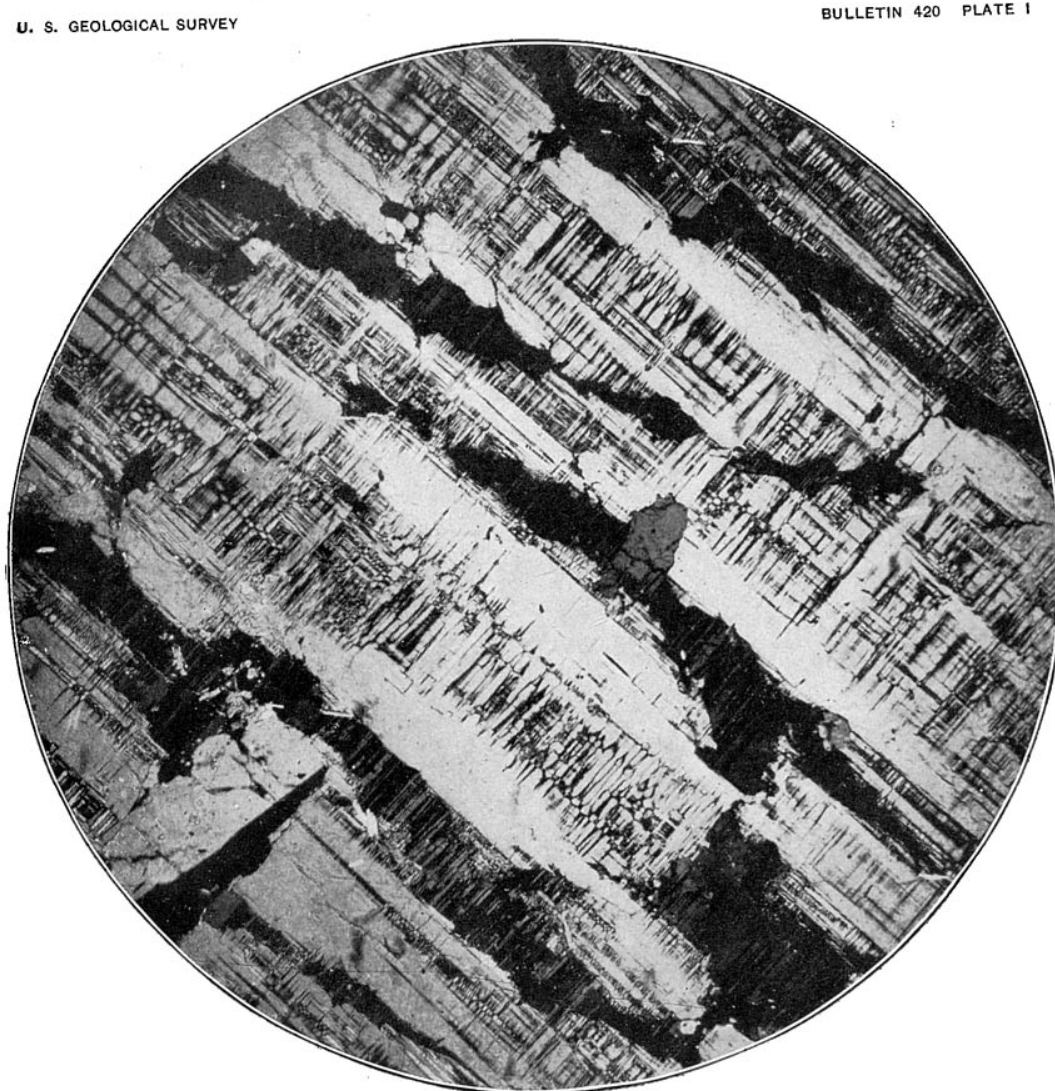

MICROPHOTOGRAPH OF THIN SECTION OF FELDSPAR FROM QUARRY OF GOLDING SONS COMPANY, GEORGETOWN, MAINE. MAGNIFIED ABOUT 40 DIAMETERS.

Showing perthitic intergrowth of potash and soda feldspar characteristic of many commercial feldspars. The Showing perthitic intergrowth of potash and a crossing at right angles are potash feldspar (microcline). The darker portions with striations in only one direction are soda feldspar (albite). 

IIME-SODA FELDSPARS, OR PLAGIOCLASES.

The lime-soda group of feldspars, the plagioclases, as they are called, form a continuous series ranging from pure soda feldspar, albite, at one end to pure lime feldspar, anorthite, at the other end. The chemical composition of albite is represented by the formula $\mathrm{NaAlSi}_{3} \mathrm{O}_{8}$ (designated $\mathrm{Ab}$ ) or $\mathrm{Na}_{2} \mathrm{O} \cdot \mathrm{Al}_{2} \mathrm{O}_{3} \cdot 6 \mathrm{SiO}_{2}$, being similar to that of orthoclase, except that soda is present in place of potash. The composition of anorthite is represented by the formula $\mathrm{CaAl}_{2} \mathrm{Si}_{2} \mathrm{O}_{8}$ (designated $\mathrm{An}$ ) or $\mathrm{CaO} \cdot \mathrm{Al}_{2} \mathrm{O}_{3} \cdot 2 \mathrm{SiO}_{2}$. The intermediate members of this feldspar series are mixtures in varying proportions of the two molecules $A b$ and $A n$ and have been divided arbitrarily, as shown in the following table:

Lime-soda series of feldspars.

Albite.............. $\mathrm{b}_{1} \mathrm{An}_{0}$ to $\mathrm{Ab}_{6} \mathrm{An}_{1}$ Labradorite..........Ab $\mathrm{b}_{1} \mathrm{An}_{1}$ to $\mathrm{Ab}_{1} \mathrm{An}_{3}$ Oligoclase ..........A $\mathrm{b}_{6} \mathrm{An}_{1}$ to $\mathrm{Ab}_{3} \mathrm{An}_{1}$ Bytownite..........A $\mathrm{b}_{1} \mathrm{An}_{3}$ to $\mathrm{Ab}_{1} \mathrm{An}_{6}$ Andesine............Ab $\mathrm{Ab}_{3} \mathrm{An}_{1}$ to $\mathrm{Ab}_{1} \mathrm{An}_{1}$ Anorthite...........Ab $\mathrm{b}_{1} \mathrm{An}_{6}$ to $\mathrm{Ab}_{0} \mathrm{An}_{1}$

The following table shows the percentages of the various oxides corresponding to each feldspar variety:

Percentage weights of the oxides in the feldspars in the lime-soda series.

\begin{tabular}{|c|c|c|c|c|}
\hline & $\mathrm{SiO}_{2}$ & $\mathrm{Al}_{2} \mathrm{O}_{3}$ & $\mathrm{Na}_{2} \mathrm{O}$ & $\mathrm{CaO}$ \\
\hline 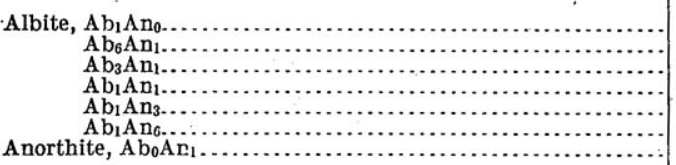 & \begin{tabular}{l|}
68.7 \\
64.9 \\
62.0 \\
55.6 \\
49.3 \\
46.6 \\
43.2
\end{tabular} & $\begin{array}{l}19.5 \\
22.1 \\
24.0 \\
28.3 \\
32.6 \\
34.4 \\
36.7\end{array}$ & \begin{tabular}{r|}
11.8 \\
10.0 \\
8.7 \\
5.7 \\
2.8 \\
1.6 \\
.0
\end{tabular} & $\begin{array}{r}0.0 \\
3.0 \\
5.3 \\
1.4 \\
15.3 \\
17.4 \\
20.1\end{array}$ \\
\hline
\end{tabular}

The field and microscopic studies made by the writer and the few analyses available indicate that most of the plagioclase present in feldspar deposits worked for pottery purposes belongs to the sodic varieties albite or oligoclase, though the more calcic varieties are probably also present in minor amounts in a few localities. The albite and oligoclase vary from pure white to pale green in color. In their commonest forms they show, as do the feldspars of the potash-soda group, two principal cleavage faces with brilliant luster, but these intersect not at $90^{\circ}$, as in orthoclase and microcline, but at about $86^{\circ}$. This difference in angle is not readily recognizable without careful measurements, and in the field albite and other lime-soda feldspars are most readily distinguished from the potash-soda feldspars by the presence in them of faint, perfectly straight striations on the most brilliant of the cleavage faces. These are the result of repeated twinning of the crystal, and are best seen by holding the crystal in the sunlight, so as to catch the reflection from the principal cleavage face. By turning the crystal slightly one way or another the striations, if present, are readily recognized. 
Pure soda feldspar, or albite $\left(\mathrm{NaAlSi}_{3} \mathrm{O}_{8}\right.$, designated $\left.\mathrm{Ab}\right)$, like potash feldspar, has no definite melting point, but, as shown by Day and Allen, ${ }^{a}$ melts at temperatures having a range of $150^{\circ} \mathrm{C}$. or more, certain portions of a crystal persisting solid while other portions are fluid. Melting in a piece of natural albite was observed to begin below $1,200^{\circ} \mathrm{C}$. and was not complete at $1,250^{\circ}$. Complete fusion takes place in albite at a somewhat lower temperature than in orthoclase and microcline. Hence, in the manufacture of pottery, a glaze prepared with albite will become fluid and will run at a kiln temperature at which a potash-feldspar glaze remains more viscous and yields good results.

The feldspars of this class that contain notable amounts of calcium have fairly well-defined melting points. These melting points, as determined by Day and Allen, ${ }^{a}$ are given below, with the determinations of their specific gravity.

Melting temperature and specific gravity of lime-soda feldspars.

\begin{tabular}{|c|c|c|}
\hline & $\begin{array}{l}\text { Melting } \\
\text { tempera- } \\
\text { ture in } \\
\text { degrees } \\
\text { centigrade. }\end{array}$ & $\begin{array}{l}\text { Specific } \\
\text { gravity of } \\
\text { crystalline } \\
\text { form. }\end{array}$ \\
\hline 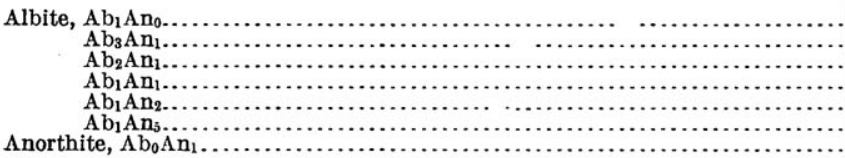 & $\begin{array}{l}1,340 \\
1,367 \\
1,419 \\
1,463 \\
1,500 \\
1,532\end{array}$ & $\begin{array}{l}2.605 \\
2.649 \\
2.660 \\
2.679 \\
2.710 \\
2.733 \\
2.765\end{array}$ \\
\hline
\end{tabular}

As shown in this table the melting points become progressively higher and the minerals become heavier with increase in the percentage of calcium.

If a melt composed solely of the constituents of pure potash feldspar or pure soda feldspar is allowed to cool, the result is invariably a glass; a crystalline product has not yet been obtained in this way. If, however, melts of the lime-rich feldspars are cooled, partial or complete crystallization usually takes place. It is this property of cooling to a glass that renders the potash- and soda-rich feldspars serviceable for use in making glazes for pottery and enamel ware. The crystallization that takes place in the lime-rich feldspars under similar conditions makes them worthless, or at least much less desirable, for these uses.

The following analyses show the chemical characters of typical feldspars that are used commercially. Most of the specimens of crude material analyzed were especially selected for their purity and are not typical of the material in commercial use. Nos. 5 and 6, on the contrary, are analyses of specimens of ground "spar" collected 
by the writer personally from the bins at feldspar mills and represent materials in actual commercial use.

Analyses of feldspars.

\begin{tabular}{|c|c|c|c|c|c|c|}
\hline & \multirow{2}{*}{1.} & \multicolumn{3}{|c|}{$\begin{array}{l}\text { Selected specimens of crude } \\
\text { feldspar. }\end{array}$} & \multicolumn{2}{|c|}{$\begin{array}{l}\text { Commercial speci- } \\
\text { mens of ground } \\
\text { feldspar. }\end{array}$} \\
\hline & & 2. & 3. & 4. & 5. & 6. \\
\hline 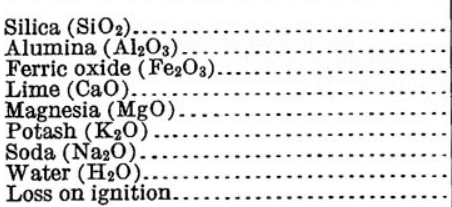 & $\begin{array}{r}64.7 \\
18.4 \\
\cdots \cdots \cdots\end{array}$ & $\begin{array}{r}64.98 \\
19.18 \\
.33 \\
\text { Trace. } \\
.25 \\
12.79 \\
2.32 \\
.48\end{array}$ & $\begin{array}{r}66.23 \\
18.77 \\
\text { Trace. } \\
.31 \\
\text { None. } \\
12.09 \\
3.11 \\
\ldots \ldots . . .\end{array}$ & $\begin{array}{r}65.95 \\
18.00 \\
.12 \\
1.05 \\
\text { Trace. } \\
12.13 \\
2.11 \\
2.1 .\end{array}$ & $\begin{array}{r}76.37 \\
a 13.87 \\
.26 \\
\text { None. } \\
5.24 \\
3.74 \\
.30\end{array}$ & $\begin{array}{r}65.87 \\
a 19.10 \\
\cdots .20 \\
.20 \\
\text { None. } \\
12.24 \\
2.56 \\
.64\end{array}$ \\
\hline - & 100.0 & 100.33 & 100.51 & 99.36 & 99.78 & 100.61 \\
\hline
\end{tabular}

$a$ Includes trace of iron and any $\mathrm{TiO}_{2}$ and $\mathrm{P}_{2} \mathrm{O}_{5}$ that may be present.

1. Theoretical composition of pure orthoclase or microcline.

2. Specimen of crude Norwegian potash feldspar, probably with some intergrown soda feldspar (albite).

Used at the Royal Porcelain Works at Charlottenburg, Sweden. From feldspar quarry of Richardson \& Sons, Bedford, Ontario. Analysis by J. B. Cochrane, Royal Mili-

tary College, Kingston, Ontario.
4. Crude pink potash feldspar (microcline), intergrown with small amounts of soda feldspar (albite). From feldspar quarry of P. H. Kinkles's Sons, Bedford, Westchester County, N. Y. Analyses made for John C. Wiarda \& Co.

5. Ground commercial feldspar from Kinkles's quarry, Bedford, N. Y., so-called No. 3 grade; used in 5. Gronufacture, but not for pottery. Sample taken by writer from bins at mill of P. H. Kinkles's Sons. Analysis by George Steiger, in laboratory of U. S. Geological Survey.

Analysis by George Steiger, in laboratory or . S. Geological Survey.

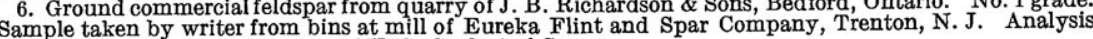
by George Steiger, in laboratory of U. S. Geological Survey.

The approximate mineral composition of the samples of the commercial ground feldspars Nos. 5 and 6 above, as computed from the analyses, is as follows:

Approximate mineral composition of feldspars Nos. 5 and 6, above.

\begin{tabular}{|c|c|c|}
\hline & 5. & 6. \\
\hline \multirow[t]{2}{*}{ 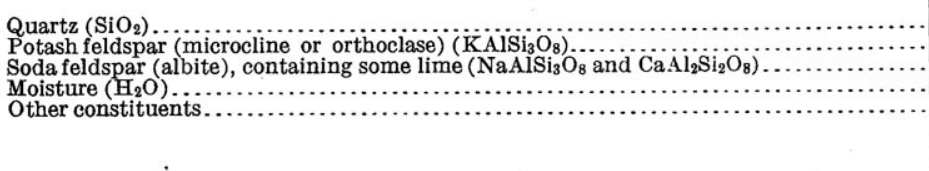 } & $\begin{array}{r}34.37 \\
30.58 \\
32.83 \\
.30 \\
1.63\end{array}$ & $\begin{array}{r}3.84 \\
72.28 \\
22.59 \\
.64 \\
1.22\end{array}$ \\
\hline & 99.71 & 100.57 \\
\hline
\end{tabular}

Samples Nos. 5 and 6 may be taken to represent, as far as the percentage of quartz is concerned, the two extremes among potash "spars" in commercial use. No. 5 is much richer in quartz and in soda feldspar than the higher grades from this same quarry and is suitable only for use in glass making, for enamel ware, and for like uses. Nö. 6 is the best grade of Canadian "spar," which is almost free from quartz and brings as high a price as any spar on the market. The bulk of the No. 2 or "standard" spar that is on the market is intermediate in its percentage of quartz between Nos. 5 and 6 , the percentage in most of it being between 15 and 25 per cent. 


\section{ORIGIN AND GEOLOGIC OCCURRENCE.}

The feldspars are among the most widely distributed minerals and occur as constituents of nearly all rocks. In most rocks, however, the feldspar is in too small grains and is too intimately associated with other minerals to be of commercial importance. Commercially valuable feldspar usually occurs as a constituent of pegmatitesrocks of extremely coarse and irregular texture. In mineral composition these rocks may vary greatly, but those of present commercial importance belong chiefly to two types: (1) The granite pegmatites, which are essentially giant granites, their minerals being the same as those most abundant in ordinary granites, and (2) the soda pegmatites, which contain no quartz, no tourmaline, and little or no mica, but consist mainly of soda feldspar (albite) with small quantities of hornblende. By far the larger number of the feldspar quarries of the United States are in deposits of granite-pegmatite; only a few, in southeastern Pennsylvania and adjacent parts of Maryland, belong to the soda pegmatite type.

It is not possible here to discuss in detail the origin of pegmatite. Nearly all the granite pegmatites are more or less closely associated with areas of granite and appear to be connected with the granites in their origin, probably representing simply one phase of the granitic intrusions. Geologists are now well agreed that those granite pegmatites which are exploited for their feldspar have been forced into the inclosing rocks in a fluid condition and that their coarse and irregular texture as compared with typical granites is due, in part at least, to the larger amounts of water vapor which they contained before solidification.

The origin of the soda feldspar pegmatites worked in southeastern Pennsylvania is not so well known and will be discussed later.

In size the pegmatite masses vary from bands a few inches across to great masses half a mile in width and traceable for a length of over a mile. The form of some of these masses is very irregular but most of them are more or less lens-shaped and were intruded along the planes of easiest fracture in the surrounding rocks. In a region where the bedding or foliation of the surrounding rocks is steeply-inclined, the pegmatite masses are usually dikelike in form, as shown in Plate II, $A$. When the bedding or foliation of the inclosing rocks is flat-lying the pegmatite masses are as a rule sill-like, as shown in Plate II, $B$. Because of this tendency of pegmatite to follow the planes of easiest parting in the bordering rocks it is possible in some areas to predict its occurrence beyond the visible outcrops, but all such predictions must be made with reservation, since the pegmatite is liable to pinch out at intervals or to cut irregularly across the trend of the inclosing rocks. Pegmatite bodies in massive rocks, 


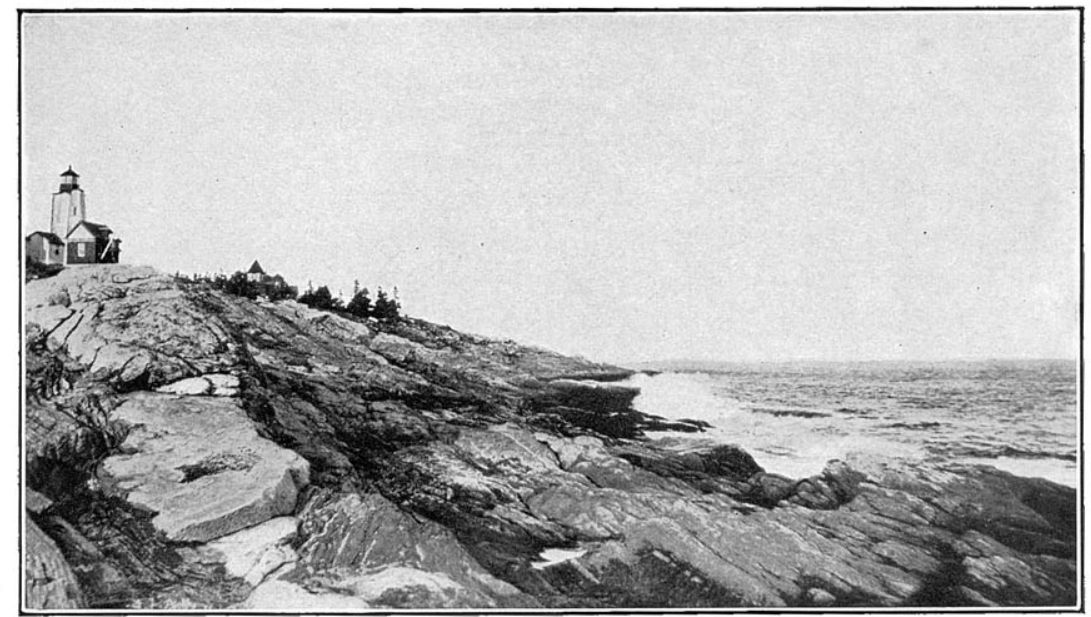

A. HIGHLY INCLINED DIKE OF PEGMATITE IN SCHISTS AT PEMAQUID POINT, MAINE. Showing characteristic swelling and pinching of such dikes.

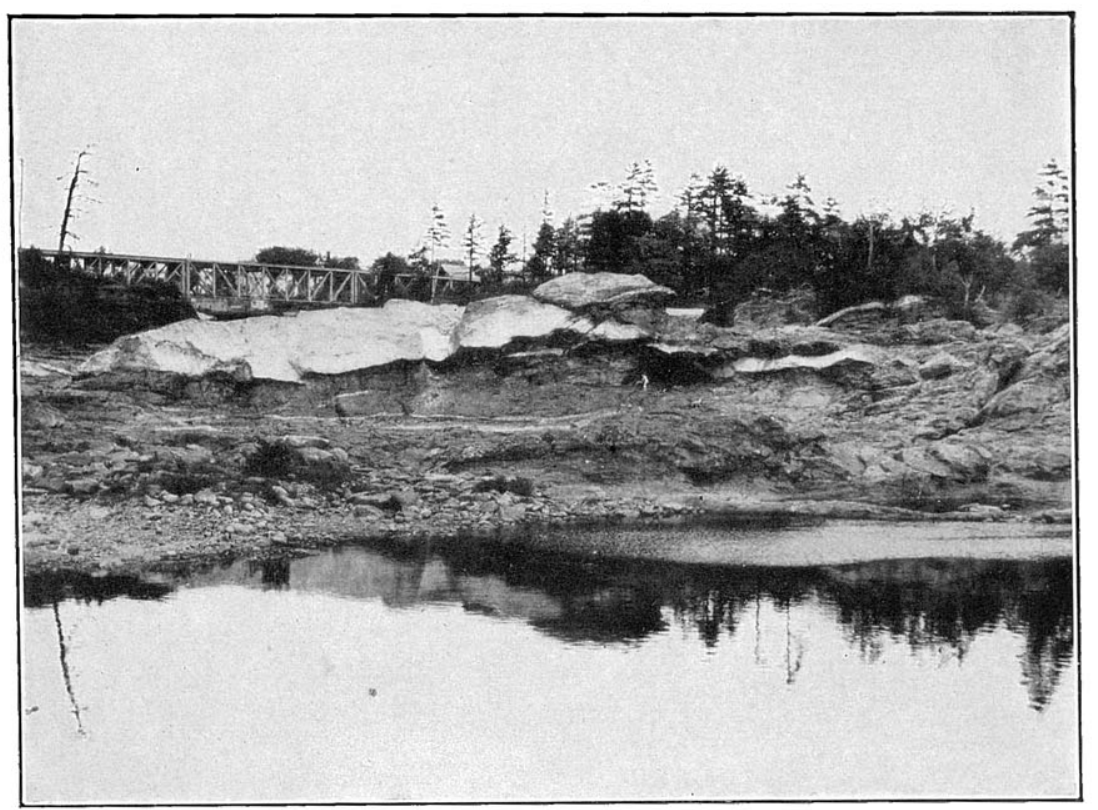

B. FLAT-LYING OR SILL-LIKE DIKE IN PEGMATITE INTRUDING GENTLY INCLINED SEDIMENTARY SCHISTS. BED OF ANDROSCOGGIN RIVER, BETWEEN RAILWAY AND HIGHWAY BRIDGES, AUBURN-LEWISTON, MịINE.

Showing lenslike form characteristic of many of these pegmatite masses. 

such as granite, may be very irregular but usually follow more or less parallel-walled fracture planes in the rocks, as shown in Plate VII, $A$.

\section{MINERALS OF THE FELDSPAR DEPOSITS.}

General composition of pegmatites.-The feldspar deposits of the granitic type in all parts of the country are very similar in essential constitution, but they differ notably with respect to the proportions in which the most abundant minerals are present and with respect to the presence or absence of certain minor constituents. In composition the pegmatites are essentially coarse granites, the principal lightcolored minerals being potash and soda feldspars, quartz, and muscovite (white mica), while the principal dark-colored constituents are biotite (black mica) and black tourmaline. In pegmatite in which biotite is abundant black tourmaline is almost-always rare or absent, and vice versa. Accessory constituents that are almost always present are garnet, magnetite, and green opaque beryl.

The most distinctive characters of the principal pegmatite minerals other than the feldspars are summarized below.

Quartz.-As a rule the quartz (silicon dioxide, $\mathrm{SiO}_{2}$ ) is white to gray in color, though some of it is pale pink (rose quartz) or, more rarely, purplish (amethyst). It is transparent to opaque, of hardness 7, not scratched by steel, without regular cleavage faces, and of conchoidal fracture. In the pegmatites it occurs in irregular masses, some of them several feet across, and also in intergrowth with feldspar and other minerals. In pockets in the pegmatites it occurs as transparent to translucent crystals which are six-sided prisms terminated by six-sided or three-sided pyramids. Crude crystalline quartz free from iron-bearing impurities has a value of $\$ 2$ to $\$ 3$ a ton at the mines when not too far from the markets. It is ground for use in the manufacture of pottery, paint, wood filler, etc. Rose quartz and amethyst, if of good quality, have gem values.

Muscovite.-Muscovite (white mica), a silicate of aluminum and potassium, of hardness 2 to $2 \frac{1}{2}$ (easily scratched with the finger nail), is transparent and colorless to pale yellowish or brownish, and is readily recognized by the ease with which it may be split into thin flexible and elastic plates. This is the mineral commonly called isinglass. Most of the muscovite found in deposits of commercial feldspar is of little value, being affected by imperfections due to fracture planes, by magnetite inclusions, etc. In the pegmatites, besides occurring in large crystals it is found in aggregates of small plates and in intergrowth with quartz. When obtainable in clear, unflawed plates it brings good prices for electrical purposes, stove fronts, etc.

Biotite.-Biotite (black or brown mica), a silicate of potash, iron, and magnesia, is similar to muscovite (white mica) in most of its 
physical properties but is dark brown to nearly black in color: In the pegmatite deposits it usually occurs in long, thin, lath-shaped crystals, some of them several feet long, which in places form more or less radiate groups. Biotite has no commercial value; on the contrary, because of its iron content, it must be carefully separated from feldspar in mining that mineral.

Tourmaline.-Tourmaline is a complex silicate of boron and aluminum, containing also either iron, magnesia, or the alkalies. It is without prominent cleavage, is of uneven and subconchoidal fracture, is not scratched by steel (hardness 7 to 7.5), and in luster is vitreous to resinous. Much of the tourmaline of pegmatite deposits is black and opaque and looks much like shiny anthracite coal, though it is much harder. This variety contains iron, is without commercial value, and must be carefully separated from feldspar in mining. Opaque to semitransparent colored varieties are also found embedded in the solid pegmatite, and transparent colored tourmalines that bring good prices as gem stones are occasionally found in pockets.

Beryl.-Beryl is a silicate of beryllium and alumina, without welldefined cleavage, with fracture subconchoidal to uneven. It is slightly translucent to transparent and ranges in color from emeraldgreen or blue-green to pink and colorless. In the pegmatites beryl usually occurs in hexagonal prisms, the largest several feet in length and a foot or more in diameter. If not transparent it is of no commercial importance, but if clear and free from flaws it has value as a gem. The pale blue-green varieties are termed aquamarine; the deeper green varieties are known as emerald.

Garnet.-A number of mineral varieties are included under the name garnet. Chemically they are silicates of aluminum with lime, iron, or manganese. The varieties most commonly found in commercial feldspar deposits are dark wine-red in color, semitransparent to opaque. These contain iron and must therefore be carefully separated from feldspar used for pottery. The crystals are usually more or less equidimensional, though they may be very irregular. In diameter not many of them exceed an inch, though a few reach 4 or 5 inches. The fracture of garnet is uneven to subconchoidal. Clear specimens have a small value as gems, but few such are found in feldspar quarries.

Accessory minerals that are present. only in certain pegmatites number more than fifty species, but perhaps the most important are lepidolite, or lithium mica; amblygonite; spodumene; blue, green, and pink tourmaline; transparent green, pale-blue, or golden beryl; colorless to amber-colored topaz; and rose and amethystine quartz. 
U. S. GEOLOGICAL SURVEY

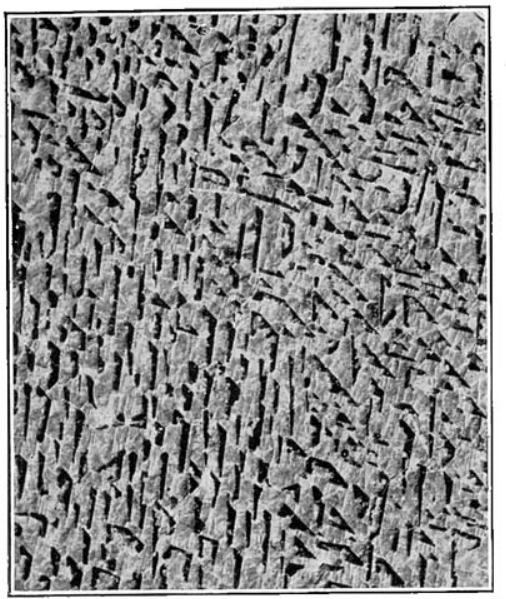

A

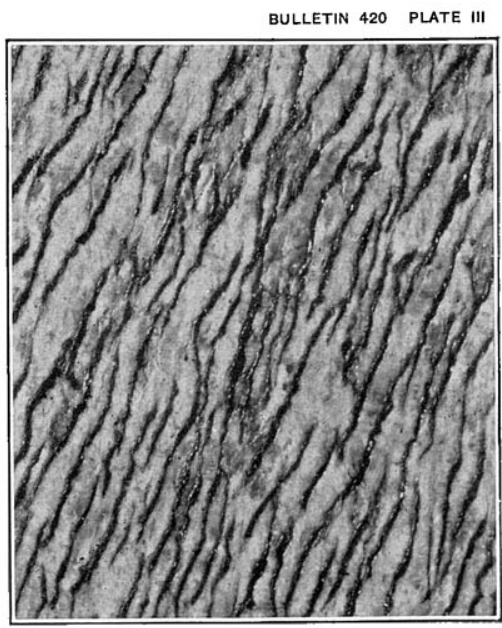

$B$

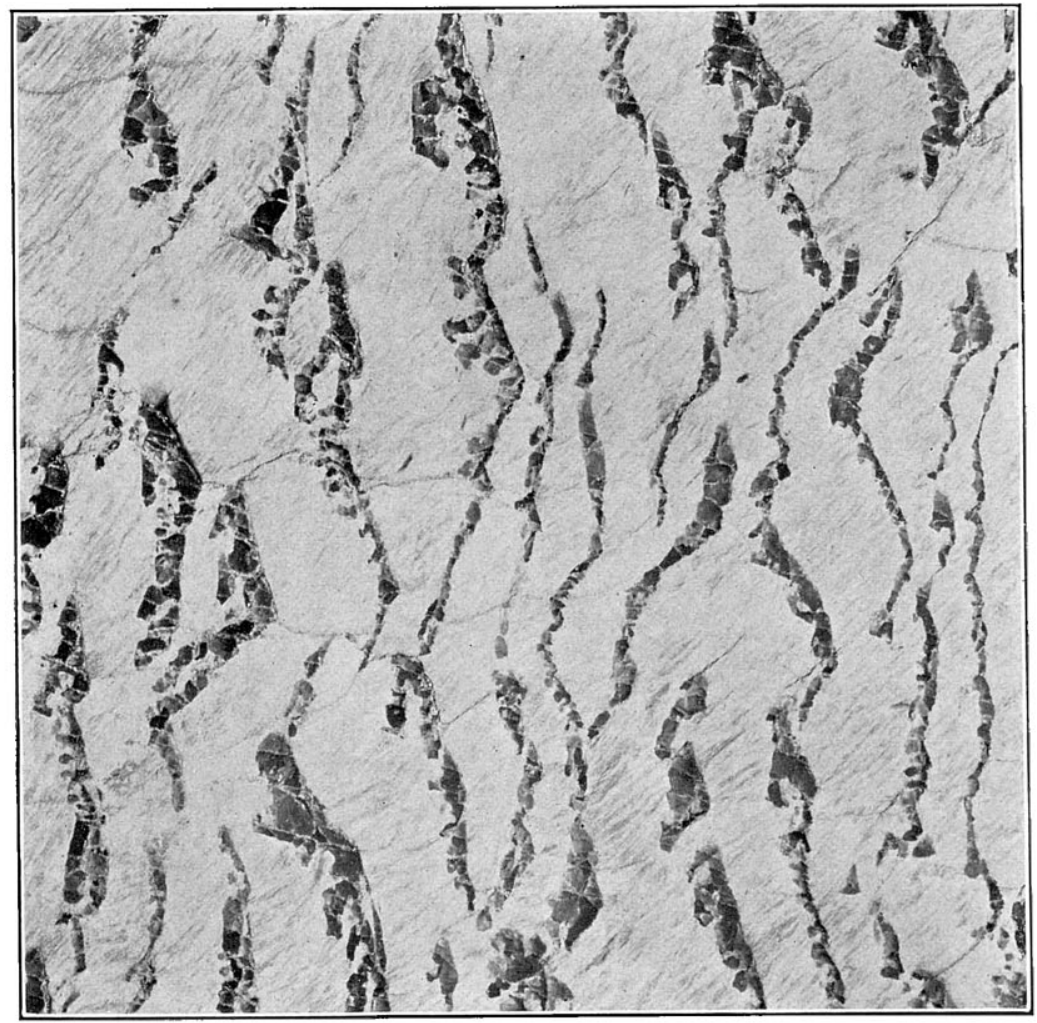

$C$

INTERGROWTHS OF FELDSPAR AND QUARTZ SHOWING CHARACTERISTIC GRAPHIC GRANITE STRUCTURE. NATURAL SIZE.

$A$, Graphic granite from Bedford, N. Y.; $B$, fine graphic granite from Topsham, Maine.; $C$, coarse graphic granite from Topsham, Maine. 

For more detailed descriptions of these minerals and for descriptions of other pegmatite minerals the reader is referred to the textbooks on mineralogy.

Crystals.-Pegmatites vary greatly in coarseness. Some, especially the narrower masses, are little coarser than coarse-grained granites, though differing strikingly from those rocks in texture; in others, single crystals of nearly pure feldspar are 20 feet across, and single crystals of beryl reach the diameter of a hogshead. Most of the deposits are nearer the lower limit of coarseness than the higher. Only the coarser deposits are commercially valuable for their feldspar, quartz, mica, or gem minerals, and these constitute a relatively small percentage of the total mass of pegmatitic material present in any district. In most of the pegmatites worked commercially the feldspar and quartz crystals will not average more than 4 or 5 feet in diameter.

The most striking characteristic of the texture of the pegmatites is its irregularity. In a mass of typical granite there is considerable uniformity in size among grains of the same mineral species, but in the pegmatites there is no such regularity; a feldspar crystal, for example, is as likely to be two or three or even ten times as large as an adjacent crystal as to be of similar size.

Graphic granite.-In most pegmatites there is much intergrowth of large single crystals of quartz and feldspar. On certain faces of the feldspar crystals of these intergrowths the quartz forms a pattern somewhat resembling the cuneiform inscriptions of the ancients. To such intergrowths the name "graphic granite" has been given from the Greek verb $r \rho \alpha \phi \varepsilon, \nu$, to write. The characteristic structure of graphic granite is shown in Plate III. Fine-grained phases may pass into coarser graphic granite and this, by decrease in the percentage of quartz, may pass into masses of pure feldspar or, by decrease in the percentage of feldspar, into masses of pure quartz. Much of the material mined for commercial use is graphic granite and numerous analyses have shown that the intergrowths in this rock are characterized by a very nearly constant proportion between the feldspar and the quartz, the feldspar forming from 70 to 80 per cent of the rock and the quartz from 20 to 30 per cent.

Analyses of four specimens of graphic granite are given below. These analyses were made by George Steiger in the laboratory of the United States Geological Survey. 
Analyses of graphic granite.

\begin{tabular}{|c|c|c|c|c|}
\hline & 1. & 2. & 3. & 4. \\
\hline \multirow{3}{*}{ 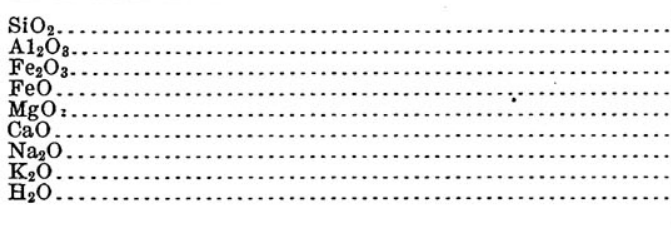 } & $\begin{array}{r}73.89 \\
13.75 \\
.26\end{array}$ & $\begin{array}{r}73.92 \\
14.26 \\
.30\end{array}$ & $\begin{array}{r}72.76 \\
a 15.47\end{array}$ & $\begin{array}{r}71.00 \\
a 16.31\end{array}$ \\
\hline & $\begin{array}{r}\text { None. } \\
\text { None. } \\
2.10 \\
9.00 \\
.24\end{array}$ & $\begin{array}{r}\text { None. } \\
\text { None. } \\
2.06 \\
8.99 \\
.11\end{array}$ & $\begin{array}{r}\text { None. } \\
.19 \\
2.35 \\
9.28 \\
.15\end{array}$ & $\begin{array}{r}\text { None. } \\
.22 \\
3.44 \\
8.66 \\
.12\end{array}$ \\
\hline & 99.24 & 99.64 & 100.20 & 99.75 \\
\hline
\end{tabular}

$a$ Includes trace of iron and any $\mathrm{TiO}_{2}$ and $\mathrm{P}_{2} \mathrm{O}_{5}$ that may be present.

1. Coarse graphic granite from Fisher's feldspar quarry (abandoned), Topsham, Me. Trace of $\mathrm{P}_{2} \mathrm{O}_{5}$. The quartz layers in this specimen average about 0.1 inch and the feldspar layers 0.4 inch across. The feldspar is cream-colored potash feldspar (microcline), finely (perthitically) intergrown with smaller amounts of soda feldspar (albite).

2. Moderately coarse graphic granite from Fisher's feldspar quarry (abandoned), Topsham, Me. Grades into No. 1. Trace of $\mathrm{P}_{2} \mathrm{O}_{5}$. The quartz layers in this specimen average about 0.05 inch across and the feldspar layers about 0.15 inch across. The feldspars are of the same character as in No. 1.

3. Fine-grained graphic granite from Kinkle's feldspar quarry, Bedford, Westchester County, N. Y. The quartz layers in this specimen average about 0.03 inch across and the feldspar layers about 0.08 inch across. The feldspars are pale-pink microcline finely intergrown with smaller amounts of soda feldspar (albite), containing a little lime.

4. Graphic granite from Andrew's quarry, Portland, Conn., varying in coarseness but all extremely fine grained. The quartz layers in this specimen average not more than 0.02 of an inch across and the feldspar layers not more than 0.05 inch across. Some small areas of pure feldspar were associated with the graphic granite in this specimen, so that the silica percentage shown in the analysis is lower than it would be for graphic granite alone of this fineness. The feldspars are white potash feldspar (microcline), intergrown with smaller amounts of soda feldspar (albite), containing a little lime.

If allowance is made for the water present and the proportion of quartz to feldspars calculated from the above analyses, the results are as follows.

Proportions of quartz and feldspar in graphic granites Nos. 1 to 4, above.

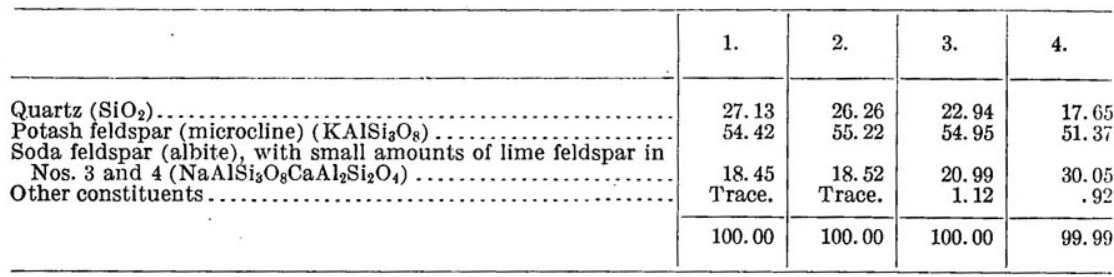

Nos. 1 and 2 in the above tables represent graphic granite from Fisher's quarry in Topsham, Me., and show practically identical proportions between the quartz and the feldspar, although No. 1 is more than twice as coarse as No. 2. In No. 3, from Bedford, N. Y., sodalime feldspar is more abundant than in Nos. 1 and 2 and the proportion of quartz is slightly less. In No. 4 some pure feldspar is associated with the graphic intergrowth of feldspar and quartz, so that the proportion of quartz in the whole specimen is lower than in any of the other samples. A graphic intergrowth of potash feldspar and quartz from Elfkarleö, Sweden, which was so fine grained that the graphic structure could be seen only under the microscope, showed on analysis about 79.2 per cent of feldspar and 20.8 per cent of quartz. From the analyses given above and from numerous 
others which have been published the conclusion seems justified that the proportion of feldspar to quartz in graphic granites, though varying somewhat according to the composition of the feldspars, is nevertheless fairly constant and is not dependent on coarseness of grain. This fact is of practical importance, since a large proportion of the commercial "spar" produced is graphic granite, and it has been the practice at some quarries to discard the finer-grained varieties on the supposition that they contained a larger percentage of quartz than the coarser kinds. Such mining practice is unwarranted, the fine graphic granite being as desirable as the coarse, though both should be mixed with a certain amount of pure feldspar in order to reduce the percentage of quartz in the ground product to between 15 and 20 per cent for the standard grade.

In most pegmatite bodies there is no regularity whatsoever in the distribution of the different minerals. The mica plates here and there show a tendency to group themselves along certain planes, but these planes seem to have no definite orientation with respect to the general outline of the deposit. A deposit that is of excellent commercial quality as regards feldspar may grade within a short distance and in a wholly irregular manner into pegmatite that is worthless because of its large percentage of quartz or its abundance of biotite, black tourmaline, or garnet.

\section{METHODS OF MINING.}

The methods of mining feldspar are very simple. The excavations are nearly all open pits, most of them of rather irregular form, the valueless portions of the pegmatite being avoided wherever possible in mining. In a few Pennsylvania quarries where the pegmatite masses are rather flat-lying and are overlain by a roof of worthless rock short tunnels have been driven from the open pits.

In Maine, Connecticut, and New York the pegmatite is usually firm and undecomposed, even in the surface outcrops, and it is necessary to sink drill holes and blast out most of the material. In Pennsylvania and Maryland, however, most of the pegmatite is much decayed at the surface and can be readily excavated with picks, shovels, and crowbars. In a few of these quarries kaolin produced by the decay of the feldspar has been found in the past in sufficient quantities to be of commercial importance, though none is now produced. This difference in the character of the pegmatite deposits in the two regions is due to the fact that the PennsylvaniaMaryland region is unglaciated, while in the more northerly region glacial ice planed. off most of the products of rock decay.

In some of the smaller quarries where the rock is firm drilling is done by hand, but in most of the larger quarries steam drills are used. The large masses are then broken with sledges into pieces 6 inches or less 
in size. If the material is to be used as poultry grit or for the manufacture of roofing materials no sorting is necessary, but material used for making pottery is hand picked at the quarry to remove the more micaceous and quartzose parts and the portions carrying iron-bearing minerals. In most of the Pennsylvania and Maryland quarries, where the weathered materials near the surface can be excavated with the aid only of the pick and shovel, screening or even washing may be necessary to free the spar from dirt. In some of the larger and deeper quarries derricks and drags are used in hoisting the spar to the surface, the material being then loaded into wagons and hauled either to the railroad for shipment or to the mills for grinding. In some quarries the wagons descend into the pit along an inclined roadway. At two important quarries wire tramways connect quarry with mill.

The cost of actual mining at most of the quarries producing feldspar of pottery grade is reported at from $\$ 2$ to $\$ 2.50$ per long ton. $\Lambda \mathrm{t}$ certain quarries where pegmatite is quarried for ready roofing, poultry grit, etc., where cobbing and hand sorting is unnecessary and where the work is conducted on a large scale, the cost may be as low as 50 cents per ton. Hauling by team from mine to mill or shipping point in most of the feldspar districts may under ordinary conditions be estimated at a contract price of 35 to 40 cents per long ton per mile.

\section{COMMERCIAL AVAILABILITY OF DEPOSITS.}

Whether it will pay to work a given feldspar deposit depends upon a number of factors, chief among which are (1) the distance from the railroad or navigable water; (2) the freight rates to principal market; ; (3) the quantity and quality of the material available; (4) the cheap)ness with which the feldspar can be mined; and (5) the market conditions. Favorable conditions with respect to some of these factors may offset unfavorable conditions with respect to others. The principal markets for the better grades of feldspar are the great pottery centers-Trenton, N. J., and East Liverpool, Ohio-so that the mines of Connecticut, Pennsylvania, and Maryland have the advantage over those in Maine and northern New York of being much closer to these markets. This superiority in position makes wagon hauls from mine to shipping point of 6 or 8 miles permissible in these Middle Atlantic States, whereas in Maine or in the Adirondack region a deposit must be much closer to the shipping point to be worked with a fair degree of profit. Pegmatite sold for roofing or poultry grit commands prices so small that hauls of more than 1 or 2 miles from mine to shipping point would in most places be prohibitive. The tariffs or hauling rates on feldspar from a number of the quarrying districts to the principal feldspar milling centers or markets are given below, 
Tariff.rates per hundredweight on feldspar for carloads having a minimum weight of 40,000 pounds, May, 1909.

Maine:

Bath to Trenton, N. J................................... $\$ 0.15$

Cathance to Trenton, N. J................................. $\quad .17$

Auburn to Trenton, N. J........................................... .16

Newं York:

Crown Point to Trenton, N. J.............................. . 17

Crown Point to New York City (commodity rate on crushed pegmatite).. $\quad .10$

Northville to Trenton, N. J............................... . 17

Pennsylvania:

Avondale to Trenton, N. J.................................... .08

Avondale to Wilmington, Del.............................. .06

Maryland:

Woodstock to Trenton, N. J. (commodity rate)................... .07

Woodstock to Wilmington, Del.............................. . $4 \frac{1}{2}$

The requirements of the potter's trade demand that in general the percentage of free quartz associated with the feldspar used for this purpose shall not exceed 20 per cent in the ground product, and certain potters demand a spar which is nearly pure, containing probably less than 5 per cent of free quartz. In order to be profitably worked, in most feldspar mines between one-fourth and one-half of the total material that must be excavated should contain less than 20 per cent of free quartz. Freshness of the feldspar, though desirable, is not essential.

A factor of the utmost importance in the mining of pottery spar is the quantity of iron-bearing minerals (black mica, hornblende, garnet, black tourmaline, etc.) which is present and the manner in which these minerals are associated with the feldspar. The requirements of the pottery trade demand that the spar be nearly free from these minerals, which if present produce upon firing brown discolorations in white wares. In order that a deposit may be worked profitably these minerals, if present in any appreciable quantity, must be so segregated in certain portions of the deposit that they can be separated from the spar without much more hand sorting and cobbing than is necessary anyway in the separation of the highly feldspathic material from that which is highly quartzose or rich in muscovite. A number of pegmatite deposits of coarse grain are rendered worthless for pottery purposes by the abundance of one or more of these ironbearing minerals. The presence here and there of minute flakes of white mica (muscovite) is characteristic even of the highest grades of commercial feldspar, and chemically this mineral is not injurious. It is, however, exceedingly difficult to pulverize the thin, flexible mica plates to a fineness equal to that required in the feldspar, and it is therefore necessary in mining to separate carefully as much of the muscovite as possible from the spar.

16779-Bull. $420-10-2$ 
Almost any coarse, undecomposed granite pegmatite is adapted to the manufacture of roofing materials and poultry grit.

Operation on a large scale with the aid of modern machinery reduces the mining cost. Favorable topographic position-a situation, for instance, that will permit the material to be excavated from a hillside opening instead of being hoisted from a pit-ilso reduces the cost of mining.

\section{METHODS OF MILLING.}

The methods used for grinding feldspar for pottery, enamel wire, etc., are similar in a general way in all of the Eastern States and are very simple. The soda spar quarried in southeastern Pennsylvania is first burned in kilns, which serves to fracture it and thus to facilitate grinding. Most feldspar, however, is fed just as it comes from the quarry into a chaser mill consisting of two buhrstone wheels, 3 to 5 feet in diameter and 1 to $1 \frac{1}{2}$ feet thick, attached to each other by a horizontal axle, as are the wheels of a cart. The horizontal axle is attached at its center to a rotating vertical shaft, which causes the buhrstone wheels to travel over a buhrstone bed, the feldspar being crushed between the wheels and the bed. In a few mills the spar before going to the chaser mills is crushed in a jaw crusher.

The material as it comes from the chasers is screened, the tailings being returned to the chaser mills for recrushing; the fines go to tube mills for final grinding. The tube mills consist of steel cylinders revolving on a horizontal axis. The cylinders are generally lined either with hard-wood blocks or with blocks made of natural or artificial siliceous brick, and are charged with Norway or French flint pebbles 2 to 3 inches across. The type of tube mill used by most feldspar grinders is 6 to 7 feet long and grinds from 2 to 3 tons of spar at one charging. Certain millers, however, claim to effect a considerable saving in power by the use of larger mills, which grind from 4 to 6 tons at one charge.

Feldspar for pottery purposes is usually ground four to six hours, and in that time most of it is reduced to a fineness of more than 200 mesh. Screen tests made by the writer on 4 samples of commercial ground pottery spar collected personally from the bins at 3 feldśpar mills showed that from 99.3 to 99.8 per cent of the material would pass through a 100-mesh screen and from 96.7 to 98.2 per cent would pass through a 200-mesh screen. A sample of No. 3 spar, used only in making glass and enamel ware, was notably coarser, 94 per cent passing through a 100 -mesh screen and 74 per cent through a 200-mesh screen. This grade is ground only for two to three hours. Some feldspar prepared for use in abrasive soaps is ground for ten hours. 
After grinding, the spar is ready for shipment either in bulk or in bags. The red spars from Bedford, N. Y., and Bedford, Ontario, have a faint pinkish tint when ground, but the cream-colored and white spars grind to a pure white. In a few mills the ground spar is allowed to settle slowly in water, so as to separate the finer from the coarser material, but this method is now rarely used.

In mills for grinding feldspar for poultry grit and roofing purposes the spar is first crushed in jaw or rotary crushers and then between steel rolls. It is then screened over vibrating screens, usually of the Newago or Jeffrey type, to the various sizes desired.

\section{USES.}

The principal consumers of feldspar are the pottery, enamel ware, enamel brick, and electrical ware manufacturers, its most important use being as a constituent part of both body and glaze in true porcelain, white ware, and vitrified sanitary ware, and as a constituent of the slip (underglaze) and glaze in so-called "porcelain" sanitary wares and enameled brick. The proportion of feldspar in the body of vitrified wares usually falls between 10 and 35 per cent. Its melting point being lower than that of the other constituents, it serves as a flux to bind the particles of clay and quartz together. In glazes the percentage of feldspar usually lies between 30 and 50 . The trade demands that feldspar for pottery purposes be nearly free from iron-bearing minerals (biotite, garnet, hornblende, tourmaline, etc.) and that it contain little if any muscovite. The requirements in regard to the percentage of free quartz vary with different potters. A few manufacturers of the finer grades of pottery demand less than 5 per cent of free quartz, and may even grind the spar themselves so as to be sure of its quality, preferring to insure a constant product even at higher cost by themselves mixing the requisite quantity of quartz with the spar. Most potters get satisfactory results with "Standard" ground spar. carrying 15 to 20 per cent of free quartz, and in some acceptable spars the percentage runs even higher. In the finely ground mixture as it comes from the mills it is difficult to separate the quartz from the feldspar by physical methods on account of the extreme fineness of the material. Chemical analysis seems to be the readiest means of determining whether its percentage is high or low.

Feldspar is also used in the manufacture of emery and carborundum wheels as a flux to bind the abrading particles together.

Small quantities of feldspar are used in the manufacture of opalescent glass. The feldspar used for this purpose is ranked as No. 3 by the miners. This generally contains more free quartz and muscovite than that used for pottery, and most of it contains also fragments of iron-bearing minerals. Most of the spars known to the writer. which 
are used for opalescent glass are rich in soda. As shown by the tests cited on page 18, they are not ground so fine as pottery spars.

Small quantities of carefully selected pure feldspar are used in the manufacture of artificial teeth. Some is used in the manufacture of scouring soaps and window washes, the fact that feldspar is slightly softer than glass rendering these soaps less liable to scratch windows or glassware than the soaps in which quartz is the abrasive substance. Two firms in New York State and one in Connecticut crush feldspar for poultry grit and for the manufacture of ready roofing.

Much interest has recently been aroused in the use of potash feldspar as a fertilizer. Potash is an important plant food, which, in fertilizers, has usually been supplied in the form of wood ashes or of easily soluble potash salts (sulphate, carbonate, or chloride) imported from Germany. The Department of Agriculture has recently made preliminary experiments to determine the availability of finely ground potash feldspar as a substitute for the more soluble potash salts. The following statement is quoted from the report on these tests: ${ }^{a}$

The evidence so far obtained appears to indicate that under certain conditions and with certain crops feldspar can be made useful if it is ground sufficiently fine. On the other hand, it is highly probable that under other conditions the addition of ground feldspar to the land would be a useless waste of money. At the present stage of the investigation it would be extremely unwise for anyone to attempt to use ground rock, except on an experimental scale that would not entail great financial loss.

If further experimentation shows that ground feldspar has a wide efficiency as a fertilizer, it will undoubtedly lead to the utilization of many of the pegmatite deposits which, because of insufficient coarseness, too large a percentage of quartz, or too great an abundance of iron-bearing minerals, are not valuable as a source of pottery material. Deposits of this kind, favorably situated with respect to the railroads, are numerous, especially in the vicinity of the active feldspar quarries. An equally important result will be the utilization of much material that is now discarded at feldspar quarries.

A number of processes have been patented in this country for the dissociation of potash feldspar to obtain the more readily soluble potash salts, but none of these have yet been successfully applied on a commercial scale. What is perhaps the most promising method effects the decomposition through electrolytic methods. ${ }^{b}$

\footnotetext{
$a$ Cushman; Allerton S., The use of feldspathic rocks as fertilizers: Bull. No. 104, Bureau of Plant Industry, U. S. Dept. Agriculture, 1907, p. 31.

$b$ Cushman, A. S., Extracting potașh from feldspar: Min. World, June 22, 1907; also U. S. Patent No. 772612 , October 18, 1904.
} 


\section{GRADES AND PRICES.}

Most dealers recognize three grades of commercial feldspar: No. 1, No. 2 (sometimes called "Standard"), and No. 3. From quarries in granite pegmatite, where most of the spar is of the potash variety, these are usually graded as follows: No. 1 is carefully selected, free from iron-bearing minerals, largely free from muscovite, and contains little or no quartz, usually less than 5 per cent. Analysis 6 of the table on page 9 shows the character of material of this grade, the feldspar analyzed having been imported from Canada. No. 2 is largely free from iron-bearing minerals and muscovite, but usually contains when ground from 15 to 20 per cent of quartz. No. 3 is not carefully selected and contains somewhat higher percentages of quartz, muscovite, and iron-bearing minerals. Spar from the soda pegmatites of southeastern Pennsylvania and adjacent parts of Maryland, being wholly free from quartz, is graded entirely on the basis of its freedom from iron-bearing minerals, principally hornblende. No. 1 is carefully selected and is practically free from such impurities; No. 2, though less carefully selected, is still fairly free from them; No. 3 is not carefully selected and carries hornblende in quantities large enough to render it unfit for use in the manufacture of pottery. It is utilized principally in making glass. Crushed pegmatite from New York State, used for poultry grit and for coverings for surfaces to give them the appearance of granite, and feldspar from Minnesota, used mainly for abrasive purposes, are graded according to coarseness.

The prices of feldspar fluctuate with general market conditions and local conditions of competition but in general are about as fellows:

Prices of feldspar f. o. b. mills.

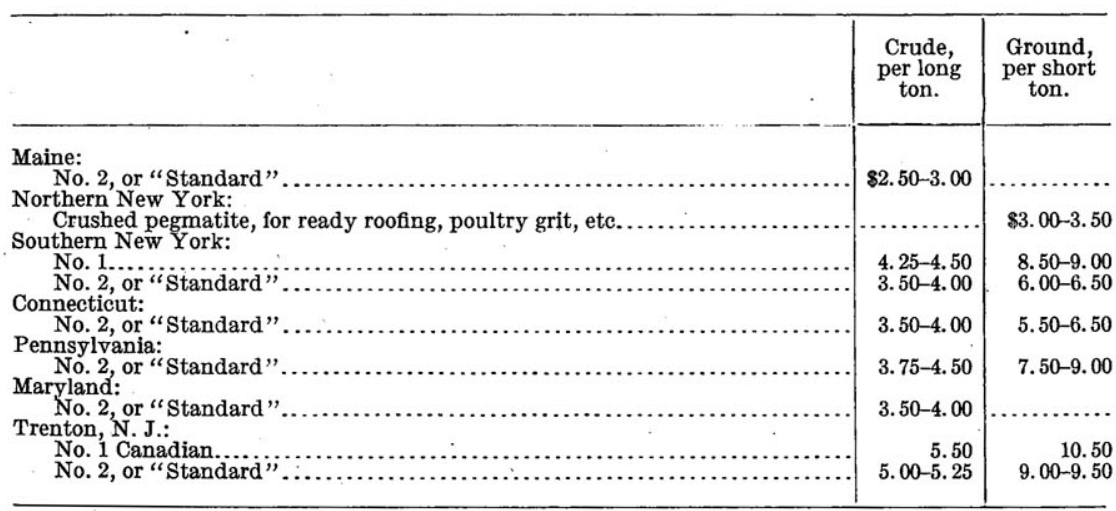

Crude No. 1 feldspar usually brings from 50 cents to $\$ 1.50$ more per ton than No. 2, and crude No. 3 brings about the same amount less. Ground No. 1 brings from $\$ 2$ to $\$ 4$ more per ton than No. 2 . 
With finer grinding, such as is demanded by some scouring soap manufacturers, the prices are proportionally higher. Very pure carefully selected potash feldspar, for use in the manufacture of artificial teeth, usually sells at from $\$ 6$ to $\$ 8$ per barrel of 350 pounds.

\section{PRODUCTION.}

The tables below show the recent production of feldspar in the United States.

Production of feldspar (exclusive of abrasive feldspar) in 1907 and 1908, by States, in short tons.

\begin{tabular}{|c|c|c|c|c|c|c|}
\hline \multirow{2}{*}{ State. } & \multicolumn{2}{|c|}{ Crude. } & \multicolumn{2}{|c|}{ Ground. } & \multicolumn{2}{|c|}{ Total. } \\
\hline & Quantity. & Value. & Quantity. & Value. & Quantity. & Value. \\
\hline 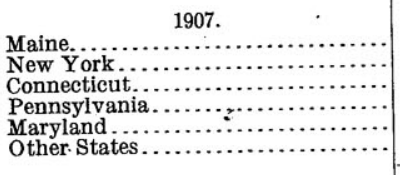 & $\begin{array}{r}45 \\
3,909 \\
10,663 \\
7,367 \\
7,169 \\
1,927\end{array}$ & $\begin{array}{r}\$ 110 \\
15,825 \\
28,433 \\
28,169 \\
23,672 \\
5,607\end{array}$ & $\begin{array}{r}16,428 \\
11,500 \\
8,380 \\
12,266 \\
3,895 \\
1,000\end{array}$ & $\begin{array}{r}\$ 157,224 \\
40,500 \\
51,770 \\
108,678 \\
34,081 \\
5,000\end{array}$ & $\begin{array}{r}16,473 \\
15,409 \\
19,043 \\
19,633 \\
11,064 \\
2,927\end{array}$ & $\begin{array}{r}\$ 157,334 \\
56,325 \\
80,203 \\
136,847 \\
57,753 \\
10,607\end{array}$ \\
\hline Total $\ldots \ldots \ldots \ldots \ldots \ldots \ldots$ & 31,080 & 101,816 & 53,469 & 397,253 & 84,549 & 499,069 \\
\hline 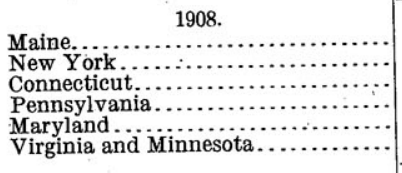 & $\begin{array}{r}168 \\
504 \\
7,775 \\
3,616 \\
6,217 \\
560\end{array}$ & $\begin{array}{r}375 \\
1,350 \\
27,753 \\
13,226 \\
21,076 \\
2,000\end{array}$ & $\begin{array}{r}13,751 \\
14,109 \\
6,425 \\
10,473 \\
3,517 \\
125\end{array}$ & $\begin{array}{r}123,034 \\
51,798 \\
38,506 \\
90,276 \\
30,774 \\
7.50\end{array}$ & $\begin{array}{r}13,919 \\
14,613 \\
14,200 \\
14,089 \\
9,734 \\
685\end{array}$ & $\begin{array}{r}123,409 \\
53,148 \\
66,259 \\
103,502 \\
51,850 \\
2,750\end{array}$ \\
\hline Total $\ldots \ldots \ldots \ldots \ldots$ & . $\quad 18,840$ & 65,780 & 48,400 & 335,138 & 67,240 & 400,918 \\
\hline
\end{tabular}

Total production of feidspar in 1907 and 1908, in short tons.

\begin{tabular}{|c|c|c|c|c|c|c|}
\hline \multirow[b]{2}{*}{. } & \multicolumn{2}{|c|}{ Crude. } & \multicolumn{2}{|c|}{ Ground. } & \multicolumn{2}{|c|}{ Total. } \\
\hline & Quantity. & Value. & Quantity. & Value. & Quantity. & Value. \\
\hline $\begin{array}{l}\text { Production of feldspar (exclusive of } \\
\text { abrasive) in } 1908 \ldots \ldots \ldots\end{array}$ & \multirow[t]{2}{*}{18,840} & \multirow[t]{2}{*}{$\$ 65,780$} & 48,400 & \multirow{2}{*}{$\begin{array}{r}\$ 335,138 \\
27,635 \\
\end{array}$} & \multirow{2}{*}{$\begin{array}{r}67,240 \\
3,234\end{array}$} & \multirow{2}{*}{$\begin{array}{r}\$ 400,918 \\
27,635\end{array}$} \\
\hline $\begin{array}{r}\text { Production of abrasive feldspar in } \\
1908 \ldots \ldots \ldots \ldots \ldots \ldots \ldots \ldots \ldots \ldots\end{array}$ & & & 3,234 & & & \\
\hline $\begin{array}{r}\text { Total production of feldspar in } \\
1908 . \\
\text { Total production of feldspar in } 1907 .\end{array}$ & $\therefore \begin{array}{r}18,840 \\
31,080\end{array}$ & $\begin{array}{r}65,780 \\
101,816\end{array}$ & $\begin{array}{l}51,634 \\
60,719\end{array}$ & $\begin{array}{l}362,773 \\
457,128\end{array}$ & $\begin{array}{l}70,474 \\
91,799\end{array}$ & $\begin{array}{l}428,553 \\
558,944\end{array}$ \\
\hline
\end{tabular}


- The production of feldspar (exclusive of abrasive feldspar) from 1903 to 1908 is given in the following table:

Production of feldspar ierclusive of abrasive feldspar), 190.3-1908, in short tons.

\begin{tabular}{|c|c|c|c|c|c|c|}
\hline \multirow{2}{*}{ Year. } & \multicolumn{2}{|c|}{ Crude. } & \multicolumn{2}{|c|}{ Ground. } & \multicolumn{2}{|c|}{ Total. } \\
\hline & Quantity. & Value. & Quantity. & Value. & Quantity. & Value. \\
\hline 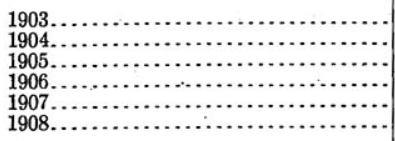 & $\begin{array}{l}13,432 \\
19,413 \\
14,517 \\
39,976 \\
31,080 \\
18,840\end{array}$ & $\begin{array}{r}\$ 51,036 \\
66,714 \\
57,976 \\
132,643 \\
101,816 \\
65,780\end{array}$ & $\begin{array}{l}28,459 \\
25,775 \\
20,902 \\
32,680 \\
53,469 \\
48,400\end{array}$ & $\begin{array}{r}\$ 205,697 \\
199,612 \\
168,181 \\
268,888 \\
397,253 \\
335,138\end{array}$ & $\begin{array}{l}41,891 \\
45,188 \\
35,419 \\
72,656 \\
84,549 \\
67,240\end{array}$ & $\begin{array}{r}\$ 256,733 \\
266,326 \\
226,157 \\
401,531 \\
499,069 \\
400,918\end{array}$ \\
\hline
\end{tabular}

LOCALITIES BY STATES,

MAINE.

The feldspar quarries of Maine are all in the south-central and southwestern part of the State, as shown in Plate IV. These portions of Maine are occupied by large areas of granite bordered by areas of highly metamorphic slates and argillaceous schists, which are intruded by granite, granite-pegmatite, and granite gneiss. It is very evident that the pegmatites are related to the granites in origin. The granites of eastern Maine are known to be late Silurian or Devonian in age and those of southwestern Maine, with their associated pegmatites, are believed to be of the same age. The bordering slates and argillaceous schists are probably Cambrian or pre-Cambrian.

In 1908 six feldspar quarries were operated in Maine by four companies, nearly all of the product being ground at feldspar mills at Cathance, Sagadahoc County, and at Littlefields, Androscoggin County. The value of the product in Maine for 1908 exceeded that. in any other State, though in number of tons the production was surpassed by Connecticut and Pennsylvania. The feldspar mined at all the Maine quarries is very similar in character and is a buff-colored potash spar.

\section{ANDROSCOGGIN COUNTY.}

AUBURN.

Pegmatite deposits at Mount Apatite, in the northern part of the town of Auburn, are worked extensively for feldspar and to some extent for other minerals valuable as gems or for cabinet specimens. Mount Apatite is a low prominence 6 miles west of the city of Auburn, near the road to Minot and about 2 miles from Littlefield, the nearest railroad station, on the Lewiston branch of the Grand Trunk Railroad. The locality was visited by the writer in August, 1906, and again in October, 1907. 
This locality was first worked for its semiprecious gem minerals and later for its quartz, but in recent years almost exclusively for feldspar. The largest producer is the Maine Feldspar Company, which has operated continuously from 1902 to the present time. The workings of this company consist of a number of small pits 75 to 150 feet long, 50 feet in average width, and 10 to 20 feet in depth. These are either close together or partly connected, and are located in a single mass of pegmatite, which constitutes the summit of the hill. Much of the hilltop is bare, but in a few places as much as 6 feet of soil must be stripped in working.

The most abundant minerals are those commonly found in granite pegmatites that are worked for feldspar, but in addition there are many minerals that.are characteristic only of gem-bearing pegmatites.

The quartz varies from white to dark gray in color and from opaque to beautifully transparent. It commonly occurs in graphic intergrowth with feldspar, but occasionally in large pure masses, and also in pockets as clusters of transparent crystals. The quartz obtained in feldspar mining is white and very pure, and is therefore well suited for any purpose for which crystalline quartz is now used. It is saved in stock piles, where it is allowed to accumulate until a sufficient amount is obtained for shipment. The profit in handling quartz located so far from the markets is very small, so that the mineral can be profitably quarried only as an accessory product.

The feldspar is mostly buff to cream color, but contains here and there bluish-gray spots and streaks due to minute inclusions. On microscopic study it is found to be of the potash varieties (orthoclase and microcline), finely (perthitically) intergrown with small amounts of soda feldspar (albite). The variety of albite known as clevelandite is abundant in aggregates of thin radiating plates in certain parts of the deposit. The "Standard" or No. 2 grade obtained at this quarry consists principally of graphic granite, with a subordinate amount of pure feldspar. Some No. 1 grade, nearly free from quartz, is also obtained, and an analysis of a sample of this made in the laboratory of the United States Geological Survey is given below.

Analysis of No. 1 ground feldspar from Auburn, Me.

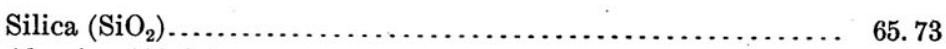

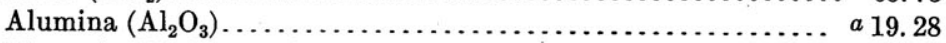

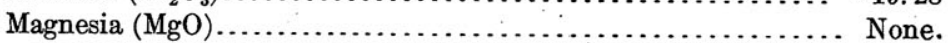

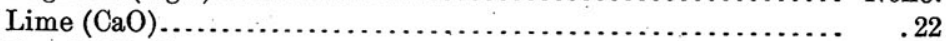

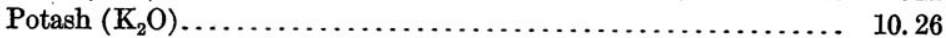

Soda $\left(\mathrm{Na}_{2} \mathrm{O}\right) \ldots \ldots \ldots \ldots \ldots \ldots \ldots \ldots \ldots \ldots \ldots \ldots \ldots \ldots \ldots \ldots \ldots \ldots \ldots \ldots \ldots \ldots \ldots, 4.08$

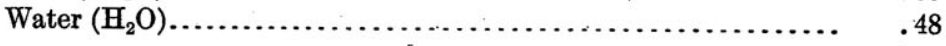

100.05 


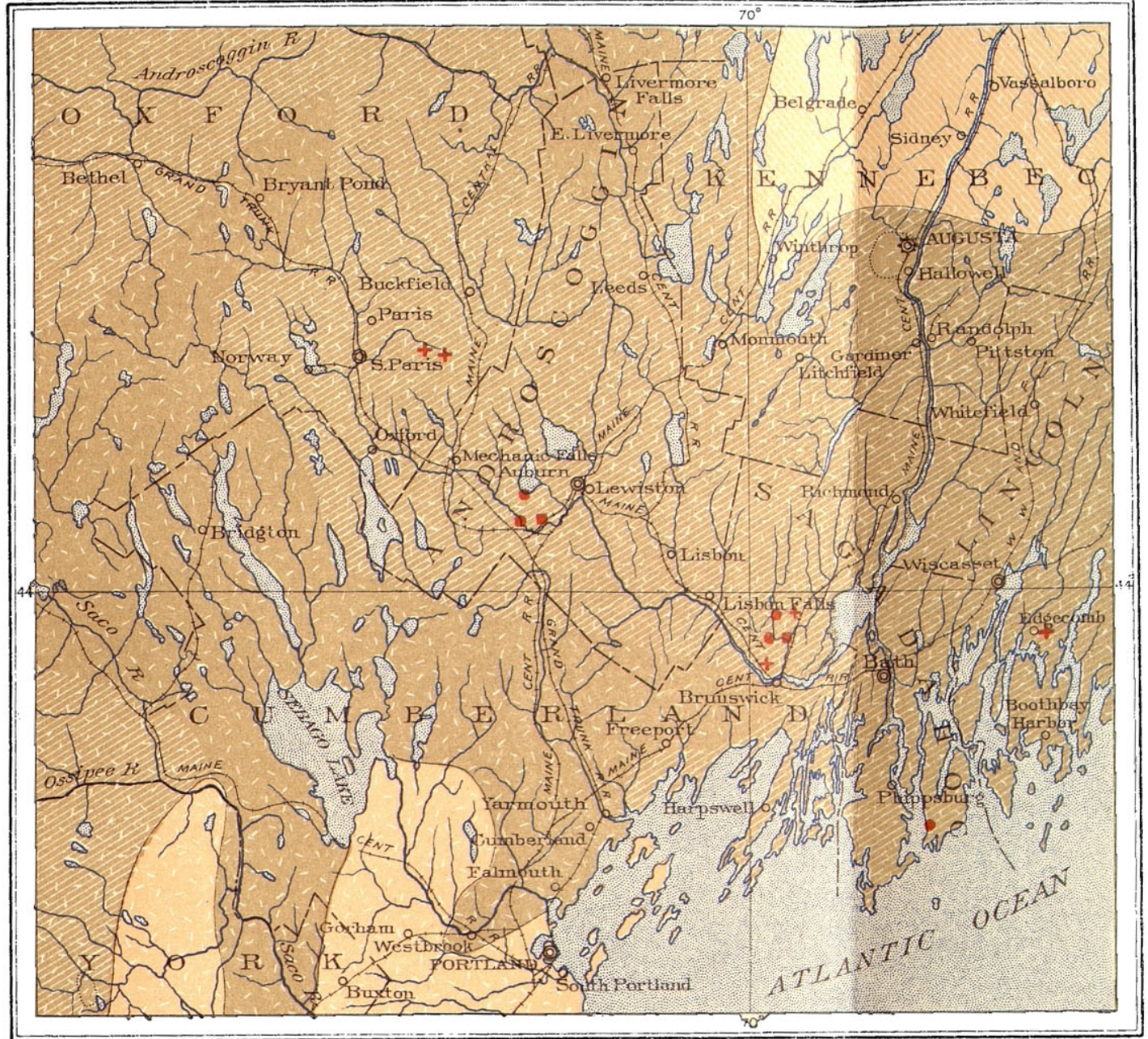

PRELIMINARY GEOLOGIC MAP OF A PORTION OF MAINE

JULILSBIEHSCO

SHOWING LOCATIONS OF FELDSFAR QUARRIES AND Mil.

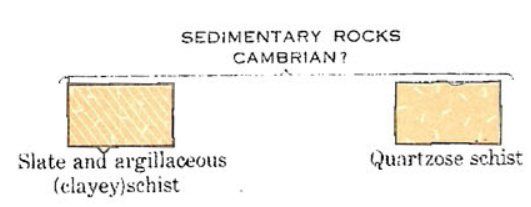

LEGEND
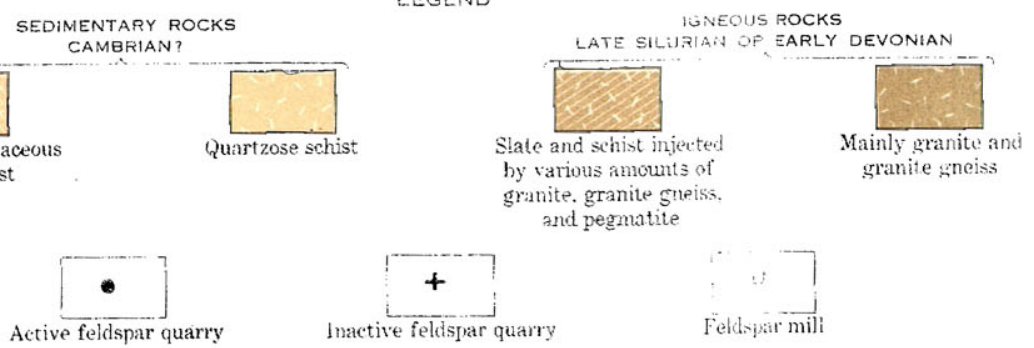

The mineral composition of this sample, as calculated from the analysis, is as follows:

Mineral composition of No. 1 ground feldspar frorn Auburn, Me.

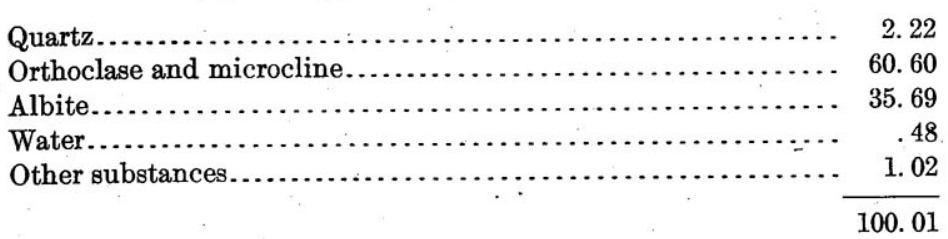

Muscovite is moderately abundant in bladelike "books," some of which are as much as a foot in length. None of it is of commercial value except as ground mica.

Biotite is only locally abundant and as a rule can be easily separated in mining.

Small garnets occur occasionally in all parts of the pegmatite, but are most abundant in the more quartzose and micaceous parts and are not present in injurious amounts in the more highly feldspathic portions.

Black tourmaline is only locally abundant and can be easily avoided in quarrying.

Bluish-green beryl is moderately abundant, and gem tourmalines are occasionally found. Many other minerals are present in subordinate amounts.

Neither the exact form nor the area of this pegmatite body could be determined, but it occupies practically the whole top of Mount Apatite, and it is probable that further stripping of the soil in the neighborhood of the present workings will disclose a considerable amount of commercial feldspar and possibly portions valuable enough to be worked for their gem minerals. There are some indications that in general this pegmatite mass is rather flat lying. Several dikes of fine-grained dark-green diabase intrude the pegmatite.

The topographic situation of this deposit, on the crest of the hill, favors the ready disposition of the waste from the quarries and also provides a downhill haul most of the way from the quarry to the mill. The excavating is accomplished by steam drilling and blasting, the material then being broken up with sledges and picked over by hand. It is hauled 2 miles by teams to the mill at Littlefield station. The force usually employed at the quarry consists of a foreman and ten laborers.

Three small pits on the southern part of the summit of Mount Apatite have been worked intermittently during the last ten years by $\mathrm{E}$. Y. Turner, of Auburn, the product being ground at the mill of the Maine Feldspar Company. The quarries were idle at the time of the writer's visit in 1906-7. The amount of material that has been 
taken out is small. The excavations consist of three pits, none of which is over 10 feet deep. The largest is 75 feet long and 30 feet wide. The pegmatite at this quarry appears to form a part of the same large pegmatite mass that is worked by the Maine Feldspar Company, but the material is of much poorer quality and there seems little prospect that the quarries will yield much feldspar of pottery grade. The excavating has been done in part by hand drilling and blasting and in part by steam drilling. The equipment includes a small derrick.

The feldspar quarried at Mount Apatite, as well as that from the Berry quarry, in Poland, is ground at a mill beside the Grand Trunk Railway at Littlefield station. The ground spar is loaded directly into cars at the mill and shipped in bulk mainly to potters at Trenton, N. J., and East Liverpool, Ohio. The equipment consists of a chaser mill, each stone of which weighs about $3 \frac{1}{2}$ tons, and a ball mill, larger than that used at most feldspar mills, grinding 3 tons at a load. The capacity of the plant is about 15 tons in twenty-four hours, and eight men and a foreman are employed. The power is supplied by a 75horsepower Westinghouse motor, the current coming from a power plant on Androscoggin River.

\section{MINOT.}

In the southeastern part of the town of Minot, near the Auburn line, some pegmatite which appears to be of commercial grade with respect to feldspar was observed on the farm of Mr. Edward Hackett. Here masses of practically pure feldspar $2 \frac{1}{2}$ to 3 feet across are associated with masses of pure quartz of about the same dimensions. Almost no biotite, garnet, or black tourmaline was seen. The pegmatite here seems to underlie a mass of fine-grained pegmatitic granite. There is no doubt of its commercial quality, but the present outcrops cover an area only about 100 feet square, so that it is uncertain whether the quantity would warrant mining. The locality is worth prospecting, however.

\section{POLAND.}

A quarry in the town of Poland, just across Androscoggin River from Mount Apatite, is operated for feldspar and occasional gem minerals by A. R. Berry, of Auburn, Me. This quarry is about 3 miles from Littlefield station on the Lewiston branch of the Grand Trunk Railway.

The quarry was opened in 1900 and has been worked intermittently on a small scale ever since. It was visited by the writer in August, 1906. The openings are very irregular, shallow, open pits, none more than 18 or 20 feet in maximum depth, and cover an area of about 2 acres. 
The general character of the pegmatite is similar to that at the Maine Feldspar Company's quarries at Mount Apatite. The rock is mainly a graphic intergrowth of quartz with buff microcline and some orthoclase. Albite in irregular crystals a few inches across is occasionally encountered.

Muscovite occurs in brush-like and rosette-like intergrowths with quartz. No plate mica occurs and no attempt has been made to market the muscovite as scrap mica.

Biotite, which is locally very abundant, occurs in irregularly disposed blades or bundle-like masses, with thin layers of feldspar or quartz between the blades. Such biotitic bundles occur in association with the coarser phases of the pegmatite and render valueless for pottery purposes much feldspar that could otherwise be used.

Black tourmaline is abundant in certain parts of the pegmatite, usually in intergrowth with quartz, one mass of intergrown quartz and black tourmaline being 10 to 12 inches across. One black tourmaline crystal observed was 5 by 12 inches in size. Colored tourmalines of gem quality are occasionally found in pockets. Other minerals are beryl, lepidolite, and herderite.

The feldspar is excavated by hand drilling. and blasting, and after hand sorting is hauled by wagons 3 miles to the mill of the Maine Feldspar Company at Littlefield station. All the spar is sold to this company and ground at this mill. Gem tourmalines and minerals of value as cabinet specimens are not found so frequently that it would pay to work the deposit for them alone. In 1906 the quarry force consisted of three men. The gems and other valuable minerals obtained are marketed irregularly through local collectors, and no estimate of their value is obtainable. The feldspar output is a few hundred tons a year. A considerable amount of commercial feldspar of pottery grade is still available at this locality.

\section{LINCOLN COUNTY.}

EDGECOMB.

A feldspar quarry that has been abandoned for many years is in the town of Edgecomb, $2 \frac{1}{2}$ miles south of the village of Newcastle and about one-half mile south of the road extending from North Edgecomb to Briar Cove, on Damariscotta River. The locality is shown on the Boothbay topographic sheet of the United States Geological Survey.

The locality was visited by the writer in August, 1906. The excavations consist of two open pits, one 150 feet long and 50 feet wide, filled with water at the time of the writer's visit; the other 50 feet long, 25 feet wide, and 15 feet deep. There is only a slight overburden of soil. The pegmatite resembles in mineral character that 
quarried at Topsham, in Sagadahoc County (see p. 38), but contains less feldspar of commercial grade.

The largest masses of pure quartz observed, which were between the two pits, were 3 feet across. In color the quartz varies from white to dark gray. It is not abundant enough to be of commercial importance.

The feldspar is buff to cream-colored orthoclase and microcline, occurring principally in graphic intergrowth with quartz. At the northwest end of the larger pit are some masses of nearly pure feldspar 3 feet across, but these are exceptional.

Biotite in the usual lath-shaped crystals, some attaining a length of 3 feet, is very abundant and is the most injurious of the mineral constituents, black tourmaline being wholly absent so far as observed.

Pink opaque garnets occur here and there, but are not abundant. Many of these are inclosed by muscovite.

As far as could be observed the quantity of feldspar suitable for the manufacture of pottery still remaining at this locality is very small, prevalence of biotite rendering most of the material worthless for the potter's use. The water in the larger pit prevented its thorough examination. An exploration of the region near this quarry yielded no information as to the trend or extent of this deposit and showed no other masses of commercially valuable feldspar. Gem minerals have not been reported from this locality and there are no indications, such as the occurrence of pockets, lepidolite, black tourmaline, etc., that any are likely to be found. Under present commercial conditions the deposit may be regarded as worked out. It may be of value in the future if some commercially practically method of separating the mica can be devised, or the feldspar may be used for purposes where the presence of black mica (biotite) is not detrimental, as for fertilizing or for poultry grit.

\section{OXFORD COUNTY.}

HEBRON.

Hibbs quarry.-A small feldspar and mica mine was opened in 1906 about $1 \frac{1}{2}$ miles north of the village of Hebron, near the Buckfield road. It is on the farm of Alton Hibbs and was operated in 1906 by J. A. Gerry, of Mechanic Falls, and W. Scott Robinson. It was abandoned in 1907 . The property was visited by the writer in August; 1906, after considerable stripping and prospecting had been done. The ledge was exposed for a distance of 300 to 350 feet along the southwest side of the valley of a small creek, the outcrop averaging in width about 30 feet, though it increased to 50 feet at one point at least. Only shallow excavations had been made at the time of the writer's visit. The exposures show numerous masses of 
pure orthoclase-microcline feldspar, 2 to 3 feet across, associated with much graphic granite. In color the spar ranges from mottled buff to blue-gray. Small amounts of the soda feldspar, albite, are occasionally found. It was estimated that the feldspar of commercial grade for pottery purposes formed about 60 per cent of the rock mined. The principal iron-bearing impurity is black tourmaline, but this is so aggregated that it can be readily separated in the mining. Biotite is present in the usual lath-shaped crystals up to 1 foot wide and 3 feet long, but is not at all abundant.

Muscovite is found in most parts of the pegmatite in small "books" up to 2 to 3 inches across, but occurs abundantly and in larger plates only at the southwest border of the pegmatite mass. Here, in a -zone averaging 3 or 4 feet in width, the mica "books" average 5 inches in diameter and one observed was 30 inches, though imperfect. It is estimated that in this zone muscovite constitutes on the average at least 10 per cent of the rock and in some places 20 per cent. Of this mica it was estimated that fully 60 per cent could be trimmed into plates, the remainder being usable only as scrap mica. Wedge structure and ruling are the common defects. Plates as large as 5 by 6 inches could be trimmed from a few of the mica books.

Exposures are not.numerous enough to reveal the full form or extent of the pegmatite mass. On its southwest side it is bounded by quartz-mica schists whose trend varies from N. $30^{\circ}$ W. to N. $50^{\circ}$ W., averaging about $\mathrm{N} .45^{\circ} \mathrm{W}$. and apparently, dipping to the northeast at an angle of about $45^{\circ}$. The northeast border of the depesit is wholly obscured by drift. The mica-rich band which follow the southwest margin of the pegmatite mass can be traced for nearty the whole distance that the pegmatite mass itself is exposed-that is, 300 to 350 feet.

From the exposures made at the time of the writer's visit this property was regarded as a promising one for both feldspar and mica mining. It seems probable that further stripping will show that the deposit extends northwest and southeast of the present exposures, and since the deposit seems to be steeply inclined there is no reason why it should not persist in good quality to a considerable depth. The development work was suspended for reasons wholly aside from the quality of the deposit. All the product must be hauled by teams 3 miles to Hebron station, on the Rangeley division of the Maine Central Railroad.

Mills feldspar quarry.-A small abandoned feldspar quarry on Number Four Hill, near the Paris-Hebron line, was visited by the writer in August, 1906. The quarry was worked by the Mount Marie Mining Company in 1901 but was soon abandoned. 
The principal pit here is about 75 feet long by 30 feet wide and 10 feet in maximum depth. A second pit close by is about 30 by 30 feet and 10 feet deep.

The bulk of the feldspar belongs to the potash varieties, orthoclase and microcline, though some albite of the clevelandite variety occurs in the coarser-grained portions. In the northwest part of the larger pit some masses of pure spar are 3 to 4 feet across. The bare ledge to the north of the smaller pit for a length of 40 or 50 feet and a width of about 30 feet shows feldspar in crystals 2 to 4 feet across but containing numerous small crystals of black tourmaline. In the northwest end of the larger pit there is a small amount of feldspar of commercial grade, but in the smaller pit and in the unopened ledge near the pits black tourmaline is so intimately and abundantly associated with the feldspar as to render most of it valueless for pottery purposes under present commercial conditions. The coarsest and most highly feldspathic portion of the deposit exposed in the larger pit contains some clevelandite and granular lepidolite and a few colored tourmalines, of pink and green tints, which are translucent to opaque. Several small pockets less than a foot in diameter were exposed at the time of the writer's visit. In some of the pockets a few transparent tourmalines of gem quality were found in the course of the mining operations. South of the workings the ledge show's very little feldspar of pottery grade, and within 200 feet there begins to be some admixture of schist with the pegmatite.

Muscovite has been saved in the mining, but most of it is what is known as wedge mica and would be valueless except as a source of ground mica. Biotite or black mica is very rare, black tourmaline being the principal iron-bearing impurity.

The trend and exact limits of this deposit could not be determined, but it is evident that the supply of feldspar here that is suitable for use in the pottery trades is very small, most of the material showing too great an abundance of black tourmaline. An examination of the whole crest of the hill south of the pits showed no spar or other minerals of commercial grade. Even if the mica and tourmalines were marketed as accessories it is probable the deposit could not be made to pay.

No mining machinery was installed at this locality. The feldspar was hauled 5 miles, mostly down grade, to South Paris, on the Grand Trunk Railroad. Only a few tons were shipped, and much spar now lies in stock piles at the quarry. 


\section{SAGADAHOC COUNTY.}

GEORGETOWN.

Golding's feldspar quarry.-One of the most productive feldspar quarries in Maine, and one which has been worked intermittently for over thirty years, is located near the east shore of Todds Bay, near the mouth of Kennebec River, and is now owned and operated by Golding's Sons Company, of Trenton, N. J. It may be reached by a drive of 11 miles from Woolwich or by steamer from. Bath to Bay Point Landing, which is only about $1 \frac{1}{2}$ miles from the quarry. The Bath topographic sheet of the United States Geological Survey covers this area. The property was visited by the writer in July, 1906, and again in November, 1908.

The excavations consist of three open pits covering an area of about 3 acres. The southernmost pit, which is the oldest and largest, had been abandoned for many years at the time of the writer's visit in 1906 , but in 1908 quarry waste that had been dumped in it was being removed and new excavating had revealed considerable amounts of excellent feldspar. It is significant that much of the waste material dumped into this pit in the early mining is of good commercial grade, according to present standards, and is being saved. In the early days graphic granite was mostly discarded and only practically pure feldspar utilized. This pit is now about 100 feet in depth. The northernmost pit, from which large amounts of spar have recently been taken, is 200 feet long in a direction N. $25^{\circ}$ E., 40 to 75 feet wide, and 20 to 30 feet deep.

The rock from this quarry that is used commercially is mainly a coarse graphic intergrowth of feldspar and quartz, and it is estimated that commercial rock forms about one-half of the total material excavated, the other half being waste, which is highly quartzose or contains muscovite or iron-bearing minerals.

Most of the feldspar is orthoclase or microcline, but there are small amounts of albite. The following analysis by the Pittsburg Testing Laboratory of the best grade of buff-colored feldspar.from this quarry was furnished by the company:

Analysis of feldspar from Golding's quarry; Georgetown, Me.

Silica $\left(\mathrm{SiO}_{2}\right)$

65.23

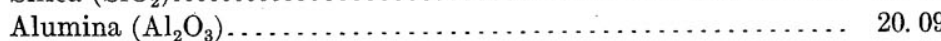

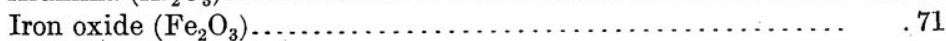

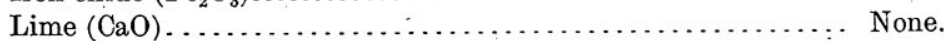

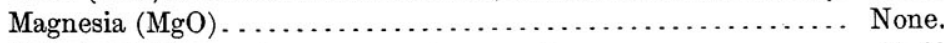

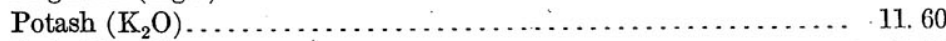

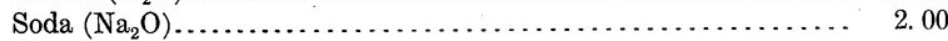

Loss on ignition................................... $\quad .36$

99. 99 
Very few large masses of pure feldspar are exposed in the present quarry openings, but it is said that in the past some single blasts have loosened 100 tons of almost pure feldspar. In the southern pit a number of masses of pure feldspar several feet across were exposed in -1908 , but most of the rock here and practically all that is exposed at the middle and northern pits is an intergrowth of quartz and feldspar. Most of this intergrowth, however, is of excellent quality for pottery uses, for as a rule injurious minerals, such as muscovite and black tourmaline, are confined to certain portions of the mass and can thus be readily separated from the rest of the rock in mining.

The quartz of this quarry is mostly gray and semiopaque, and much of it has a granular appearance. In a few places it is slightly pinkish in hue. Most of the masses of pure quartz are small, the largest observed by the writer, a mass in the northernmost pit, being 6 feet across. It is not utilized commercially.

Muscovite is not present in sufficient amounts and is not of the proper quality to be of commercial importance. Graphic intergrowths of quartz and muscovite are found locally, as are rounded aggregates that are made up almost entirely of small muscovite crystals and are similar to those at the G. D. Willes quarry in Topsham.

Biotite is almost entirely absent. In its stead occurs black tourmaline, which is locally very abundant in prismatic crystals, some of them $2 \frac{1}{2}$ to 3 inches in diameter and a foot or more in length. The tourmaline is not evenly distributed through the pegmatite, but is confined almost entirely to certain irregular zones which may be avoided or discarded in the quarrying process. It is more abundantly associated with the quartz than with the feldspar.

Garnet occurs in deep flesh-colored crystals, most of them small and associated with quartz and muscovite.

Light-green opaque beryl is found occasionally, one mass penetrating quartz being 14 inches long and 4 inches in diameter.

The contact of the pegmatite with other rocks is not exposed in any of the quarry openings, but is fairly well shown a few rods northeast of the quarry, near the highest part of the hill on which the quarry is located. Here the bordering rocks are schists with strike slightly east of north and dip almost vertical. The contact nearly parallels the trend of the schists and the pegmatite is plainly intrusive, locally cutting across the foliation of the schists and sending off broad - tongues into them.

The excavations at the Golding quarry cover almost the whole outcrop of the pegmatite body there mined. Future quarrying will probably consist largely in deepening the present pit, but there is reason to expect that the deposit will continue of good quality and of about the same dimensions to a considerable depth. A number of other pegmatite dikes of similar size and shape occur in this vicinity, 
and some of them have been worked to a slight extent. None of these, as far as seen, showed any large amount of feldspar of commercial grade.

The rock is excavated by steam drilling and dynamite blasting, and that in the largest pit is hoisted by derrick and hoisting engine. It is broken up and sorted by hand and then loaded onto wagons which haul it a quarter of a mile to the shore, where it is transferred to small sailing barges, which convey it either to vessels for shipment to Trenton by water, or up Kennebec River 10 miles to Bath, for shipment by rail. About fifteen men are usually employed in this quarry.

Abandoned feldspar quarry.-A small feldspar quarry, now abandoned and partly filled with water, is located one-half mile east of the Goldings quarry, near the head of Sagadahoc Bay and east of the highway. It is a single pit about 75 feet long, 35 feet wide, and probably 30 to 40 feet deep, though only 25 feet of wall shows above the water level. The rock is similar in nearly every respect to that quarried at the Goldings quarry, but the area of the deposit seems to be very small, schist occurring within a hundred feet to the north, west, and south of the pit.

\section{TOPSHAM.}

General character and relations of the deposits.-The feldspar quarries in the town of Topsham all lie within a belt about a mile wide, which extends northeastward from Mount Ararat, near Topsham village, nearly to the Topsham-Bowdoinham line. Within this belt are eight quarries, only three of which are now active, and, in addition, a number of prospect pits. It is significant that the line of distribution of these quarries corresponds closely with the trend of the metamorphosed sedimentary schists into which the pegmatites were intruded. Because of the depth of the soil it is impossible to determine exactly the limits of the coarse pegmatite bodies exposed at each of these eight quarries, but a study of the rocks between the various quarries shows that the pegmatite bodies which are worked are not parts of a single mass, but are more or less detached masses of pegmatite in a region where the rocks are mainly schists. Within this belt, however, the pegmatitic intrusions are more numerous and some of them are of coarser texture than in the surrounding country. If the form of the smaller and finer-grained pegmatite masses may be taken as an index to the form of the larger and coarser ones that are commercially valuable most of the latter are probably somewhat elongate in a direction slightly east of north, parallel to the general trend of the inclosing schists and gneisses.

Feldspar is the only mineral of much commercial importance at any of these quarries. Quartz of excellent quality is present in considerable amounts, and much of it is saved in quarrying, though at 16779-Bull. 420-10-3 
present it finds but slight market. At some of the quarries tourmalines and aquamarines of gem -quality are now and then obtained. A description of the quarries in the order of their distribution from southwest to northeast is given below.

Mount Ararat feldspar quarries.-Feldspar and quartz have been obtained from a quarry on the eastern slope of Mount Ararat, about a mile north of Topsham village. The deeper part of the hillside excavation here is about 40 feet long from east to west, 10 feet wide, and 12 feet in maximum depth. A shallow excavation adjacent to the northwest part of the deeper pit covers an area about 20 by 30 feet in size. The quarry has not been operated for several years.

The lower pit exposes considerable amounts of clear white, gray, and nearly black semiopaque quartz, but shows few masses of pure feldspar more than 3 to 4 inches in diameter. Several tons of quartz that have been saved in the quarrying process are now piled near the pit, though feldspar was the principal mineral sought. The feldspar is cream colored to nearly white and is shown by microscopic examination to be principally microcline with occasional very small amounts of the white soda feldspar, albite. In the upper and shallower portion of the quarry the amount of pure quartz is less and the amount of pure feldspar is greater than in the lower portion. Some of the masses of pure feldspar there are 3 to 4 feet across. They grade into a coarse graphic intergrowth of quartz and feldspar, which in turn grades into extremely fine graphic granite. Only the pure feldspar and the coarse graphic granite were used commercially. Among the iron-bearing minerals that would injure the quality of the feldspar for pottery purposes black tourmaline is almost entirely absent and black mica (biotite) is rare. Garnet is a rather abundant constituent, but is associated mainly with the muscovite and with the finer-grained portions of the pegmatite and only rarely with the more feldspathic parts that are commercially available. Magnetite occurs rarely, in small irregular octahedra.

Muscovite, or white mica, is also an abundant constituent of the pegmatite exposed in the upper pit. It is pale green to nearly colorless and occurs in "books," some of which are 8 to 10 inches in diameter. The great bulk of the muscovite is of the wedge variety and shows twinning, and could be utilized commercially only as scrap mica. A small amount is plate mica and splits readily into sheets which, when trimmed, may measure 4 by 5 inches, though most of them are smaller. As a rule, however, this plate mica incloses between its lamellæ thin, branching crystals of magnetite, and would therefore be useless for electrical and most other purposes to which plate mica is usually applied.

Occasionally small masses of columbite, most of them exhibiting very imperfect crystal forms, are found in the quartz-feldspar masses. 
The wall rock of schist or gneiss is nowhere exposed at this quarry, and the depth of the soil makes it impossible to trace exactly the limits of the deposit. If we may judge from neighboring masses of pegmatite whose boundaries are exposed, this mass is probably more or less irregular in outline and somewhat elongate in a direction parallel to the trend of the neighboring schists - that is, somewhat east of north. The deposit appears to be not very extensive but the quality of the product is good, and there seems to be warrant for further development work on a small scale.

A second small feldspar quarry is on the northern slope of Mount Ararat. It consists of a single hillside pit about 150 feet long, 30 feet in average width, and 20 feet in greatest depth. It is not now worked, but was worked as recently as 1905 . The rock at this quarry is a wholly irregular association of quartz, feldspar, muscovite, biotite, and garnet, with smaller amounts of rarer minerals. The quartz is prevailingly dark gray in color and semiopaque, though here and there it is white and in a few places nearly black. Some of the pure quartz masses are 3 to 4 feet across. One flat-lying irregular mass exposed at the base of one of the quarry walls is 5 feet in maximum width and 25 feet in length.

Most of the feldspar is pale pink, but certain portions are cream colored, while other parts are decidedly red. Microscopic examination shows that the feldspar belongs mainly to the potash varieties, orthoclase and microcline, the former greatly predominating. With these are associated small amounts of the soda feldspar, albite, which is here and there intergrown microscopically with the orthoclase or microcline. Throughout the greater part of the quarry the masses of pure feldspar are not more than 4 to 5 inches across, though a few crystals 2 to 3 feet across are found. The bulk of the material quarried for pottery use is a graphic intergrowth of feldspar and quartz, most of it coarser than that found at the quarry on the eastern slope of Mount Ararat. Some of the quartz thus intergrown with the feldspar assumes branching or dendritic forms, a characteristic not generally observed in pegmatite deposits.

Muscovite of the wedge variety occurs sparingly in "books" up to 6 inches in greatest diameter and also in intergrowth with quartz and feldspar. No clear plate mica was observed.

Biotite is much more abundant here than at the quarry on the east side of Mount Ararat and predominates over muscovite. It occurs in the characteristic lath-shaped crystals, many of them 2 feet long, 4 to 5 inches wide, and one-half an inch to 1 inch thick. The largest biotite crystal observed was $3 \frac{1}{2}$ feet long, $2 \frac{1}{2}$ feet wide, and 1 to 2 inches thick. These crystals penetrate the pegmatite mass in every conceivable direction. 
Garnet is rather abundant and as a rule is dark red and submetallic in appearance. It is here and there intergrown with quartz or with quartz and muscovite. One garnet crystal was $2 \frac{1}{2}$ inches across. Garnet is most abundant in the finer-grained portion of the pegmatite and in those portions that are rich in muscovite. It is rare in the parts that are used commercially. Magnetite occurs only rarely, in imperfect octahedra showing step structure.

Schists and gneisses are nowhere exposed in this quarry and outcrops near the quarry are not numerous, so that it is impossible to determine the form or area of this body of pegmatite. On the north wall of the quarry a small mass of fine-grained granite showing locally a somewhat gneissic structure is exposed and is intruded by the pegmatite, which cuts across the banding of the granite gneiss.

The amount of feldspar of commercial quality now exposed is not large and the abundance of biotite and garnet render much of the material valueless for pottery uses. The extent of the deposit can not be determined, but it is probably not very great. Further development on a small scale could perhaps be profitably undertaken and might reveal some good spar not now exposed. The deposit is 2 miles from the Maine Central Railroad station at Topsham. The nearest point on the railroad is only three-fourths of a mile southeast of this quarry and the one previously described, but no wagon road is available for transportation in this direction.

Fisher's feldspar quarry.-A small quarry not now worked is situated $1 \frac{1}{4}$ miles west-northwest of Cathance station on a southern hill slope in the valley of Cathance River. This quarry, which was formerly operated for feldspar by J. A. Fisher, consists of a single pit about 150 feet long from north to south, 20 feet or so in average width, and about 18 feet in maximum depth.

Here, as in most other feldspar quarries, there is no regularity in the arrangement of the constituent minerals with the single exception of muscovite, which occurs principally along certain zones whose trends, however, have no definite relation to the general outlines of the deposit.

The quartz is white to gray in color, but no very large masses are exposed.

The feldspar is cream colored and is shown by microscopic examination to be microcline with some orthoclase finely intergrown with small amounts of soda feldspar (albite). One mass of pure feldspar exposed on the west wall of the quarry was 3 to 4 feet wide and 10 feet high. This passes by perfect gradations into a coarse graphic intergrowth with quartz, and this in turn into a much finer graphic intergrowth. Here, as in most other feldspar quarries, the coarse graphic granite forms the bulk of the material mined for pottery purposes. 
The chemical and mineralogical composition of graphic granites from this quarry are shown on page 14 .

The muscovite, so far as the present exposures show, is all of the wedge variety. It is confined mainly to certain zones which penetrate the pegmatite irregularly. None is of commercial value except for grinding. Being localized in this manner it does not seriously interfere with the feldspar mining. Graphic intergrowths of quartz and muscovite are common. In some parts of the pegmatite, biotite dominates over muscovite, but is usually most abundant in the finergrained portions of the pegmatite.

Outcrops are not numerous enough in the immediate vicinity to determine the extent or form of the pegmatite body. The materials exposed in the present excavation indicate that a considerable supply of spar is still available and seem to warrant further development.

William Willes feldspar quarry.-A small quarry opened early in 1906 , at a point $1 \frac{1}{2}$ miles northwest of Cathance station, is operated by William Willes for the Trenton Flint and Spar Company. It occupies an area of a little.more than 1 acre, and the average depth of excavation is about 10 feet. Natural drainage is possible at present depth, but further excavation will necessitate pumping. The rock is a wholly irregular association of quartz, feldspar, mica, and rarer minerals.

The quartz is mainly light gray in color and occurs locally in pure masses 5 or 6 feet in diameter. Many of even the larger quartz masses exhibit crystal faces along their contact with other minerals. Quartz is saved in the quarrying process, though it finds only a very irregular market.

The feldspar is buff colored and is mainly orthoclase and microcline. The soda variety, albite, also occurs, but forms only a small percentage of the total mass of feldspar. A few crystals of albite are 4 to 5 inches across. The great bulk of the material quarried for pottery purposes here, as at most of the Maine feldspar quarries, is a coarse graphic intergrowth of quartz with potash feldspar. In the northern part of the quarry a mass of pure feldspar 10 feet across is exposed on a glaciated surface.

Muscovite occurs in graphic intergrowth with quartz and also in "books," most of which are of the variety known as wedge mica. Some of these "books" are 10 inches across. The total amount of muscovite present is not sufficient to make it worth while to save it in the quarrying process.

Biotite is about as abundant as muscovite and occurs in the characteristic lath-shaped crystals. One of these was 4 feet long, 8 inches wide, and 1 inch thick. Much of the biotite is decomposed to what appears to be chlorite colored with hematite. 
Garnet is moderately abundant, usually occurring in compound crystals of dark-red color with submetallic luster.

Beryl is moderately abundant, some hexagonal crystals being 10 inches in diameter. Some of the smaller crystals are partly transparent and have been sold to mineral collectors.

Columbite is found occasionally in small, imperfectly developed crystals, but is not sufficiently abundant to be of commercial importance.

In one place in the quarry a small amount of hornblendic granite gneiss occurs. The pegmatite boundary cuts across the foliation of the granite gneiss and is plainly somewhat later. The exact attitude and boundaries of the pegmatite mass could not be determined because of the scarcity of outcrops in the vicinity of the quarry, but it is probable that further stripping near the present workings will reveal considerable amounts of commercially valuable spar.

At the time of the writer's visit seven laborers were employed in the quarry besides the foreman and the superintendent. The rock is hauled by two-horse teams a distance of $1 \frac{1}{4}$ miles to the feldspar mill near Cathance station.

Maine Feldspar Company's feldspar quarry.-A small feldspar quarry a few rods southeast of that operated by William Willes was opened in 1906 by the Maine Feldspar Company of Auburn, Me. The rock is similar in every way to that at the William Willes quarry. The rock is hauled by team about $1 \frac{1}{4}$ miles to Cathance station and from there shipped by rail to the Maine Feldspar Company's mill at Littlefield, 3 miles southwest of Auburn.

G. D. Willes feldspar quarry.-The oldest and by far the largest of the Topsham quarries is about 2 miles northwest of Cathance station and is operated for the Trenton Flint and Spar Company by G. D. Willes. It is an irregular opening covering several acres and the material is excavated from several levels, the greatest depth being about 50 feet. (See Pl. V, A.)

Although the great bulk of the commercial spar now taken from this quarry is a coarse graphic intergrowth of feldspar and quartz, it has yielded masses of pure quartz and of pure feldspar that are larger than those seen at any other quarry in the State. A single mass of pure white quartz in the northern part of the quarry is 50 feet long and is exposed for a height of 10 feet. The pegmatite is in general coarser at the north end than at the south end of this quarry.

The feldspar also occurs occasionally in crystals of large size, one in the northern part of the quarry being 15 feet across. The bulk of the feldspar, as shown by microscopic study, is of the potash varieties orthoclase and microcline, finely intergrown with soda feldspar (albite), and there are small masses, most of them only a few inches across, of pure white albite. 
U. S. GEOLOGICAL SURVEY

BULLETIN 420 PLATE V

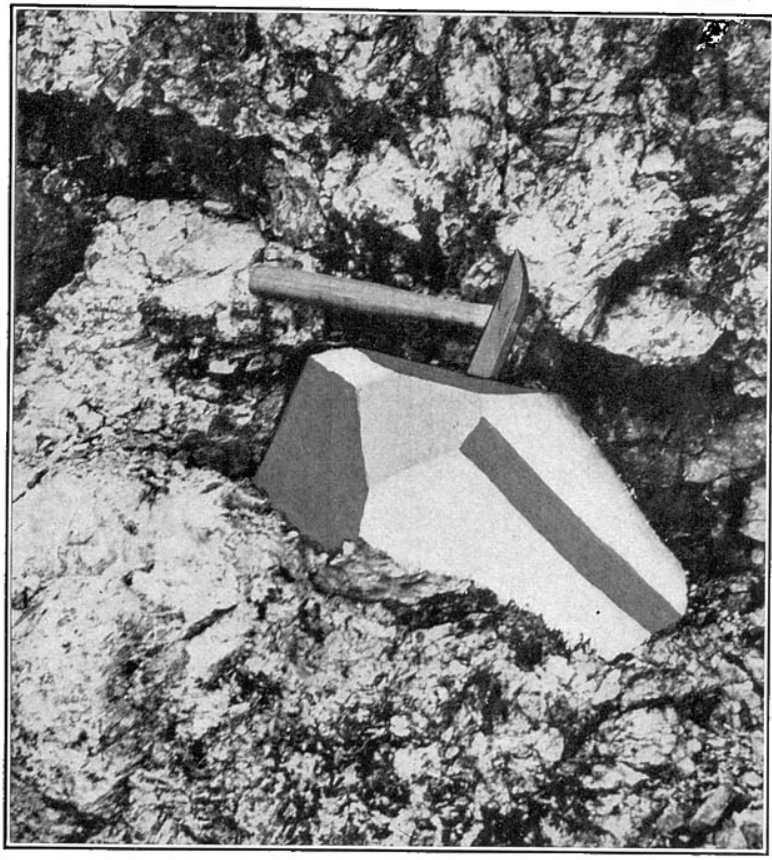

A. CRYSTAL OF MICROCLINE FELDSPAR IN ROARING CREEK FELDSPAR QUARRY, CONNECTICUT.

Crystal faces painted for photographing. Front face is the $b$-pinacoid. Hammer rests on the $c$-pinacoid. The crystal was originally entirely inclosed by pegmatite.

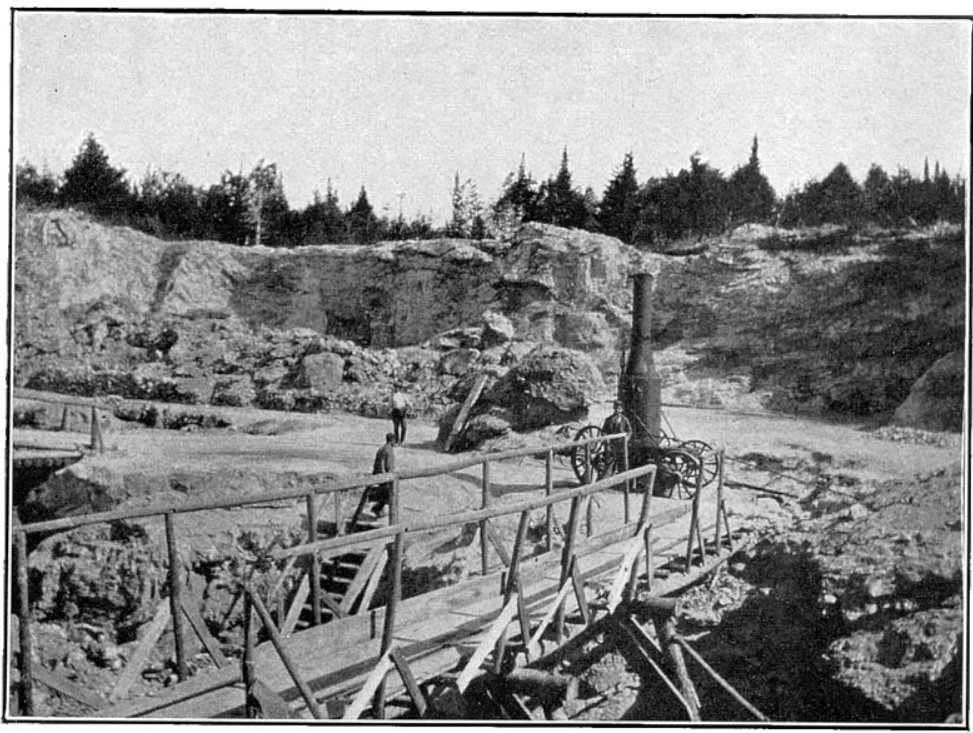

B. PORTION OF G. D. WILLES FELDSPAR QUARRY, TOPSHAM, MAINE Photograph by Prof. Leslie A. Lee. 

Muscovite is concentrated principally along certain belts that traverse the pegmatite mass in various directions, but in the southern part of the quarry it occurs in rounded aggregates, some of them 5 feet across, of small, heterogeneously arranged plates averaging about one-fourth inch across. Some graphic intergrowths of quartz and muscovite occur, but they are not abundant. Under present conditions it would probably not pay to save as scrap mica the muscovite obtained in mining the feldspar. No plate mica occurs.

Biotite is moderately abundant in certain parts of the pegmatite, penetrating the feldspar and quartz as long, lath-shaped masses, the largest of them 2 yards long by 3 inches wide and one-fourth of an inch thick.

Small garnets here, as in most other feldspar quarries, are abundant only in certain portions of the deposit, the coarser graphic granite and the pure feldspar being almost entirely free from them, and they can be readily separated in mining.

Many cavities up to 1 foot in diameter and of various forms are found in the coarser portions of the pegmatite in the northern part of the quarry. Most of these cavities contain groups of somewhat smoky semitransparent quartz crystals, some of which make handsome cabinet specimens. In a few of these cavities transparent green tourmalines and aquamarines (beryl) of gem quality have been found.

The schists and gneisses that border the pegmatite are exposed at the southern end of the quarry, where they show evidence of some softening as a result of the pegmatite intrusion. In general they lie rather flat. Probably the pegmatite mass is also in general somewhat flat lying, though very irregular. It is probable that the workable pegmatite does not extend southward much beyond the limits of the present pit, but it is known to extend north of the Willes quarry into property that is said to be controlled by the Maine Feldspar Company. Here it has been worked in the past from a number of small openings and very considerable amounts of commercial spar are still available.

The methods of operation at this quarry are somewhat antiquated for a working of this size, the drilling all being done by hand and the blasting by black powder. A tramway carries the waste to dump piles and the good rock to stock sheds, from which it is loaded into wagons and hauled $1 \frac{3}{4}$ miles to the mill described below, near Cathance station.

Feldspar mill of the Trenton Flint and Spar Company.-The feldspar mill of the Trenton Flint and Spar Company is on Cathance River about one-half mile north of Cathance station. During high water it utilizes the water power of this small river, but it is also provided with steam power. The equipment consists of three chaser mills and four ball mills of the types usually used in feldspar mills. The 
grinding process is that described on page 18. The capacity of the mill is about 16 tons in twenty-four hours, the ground spar being hauled by wagon for one-half mile from the mill to Cathance station, on the Maine Central Railroad, where it is loaded for shipment.

Feldspar quarry in northern part of the town of Topsham.-A feldspar quarry one-half mile west of Cathance River, and 1 mile south of the Topsham-Bowdoinham line was formerly operated by the Trenton Flint and Spar Company, the rock being hauled by team 2 miles to the mill near Cathance station. This quarry, which is on the western slope of the river valley, is an irregular opening extending north and south along the hill slope for about 200 feet and running into the hill for about 40 feet. There is no regularity in the arrangement of the pegmatite constituents.

The quartz is prevailingly white or light gray, though some of it is smoky.

The feldspar is white to cream-colored and is shown by microscopic examination to be mainly orthoclase, though it includes small amounts of albite and microcline. The albite in places forms a fine microscopic intergrowth (microperthite) with the orthoclase; some masses of pure feldspar here have a diameter of 4 to 5 feet, but the bulk of the material quarried for the manufacture of pottery was a graphic intergrowth of quartz and feldspar.

Muscovite, mostly pale green in color, is as a rule graphically intergrown with quartz, though there are a few "books" of clean mica, the largest 5 or 6 inches in diameter. All of those observed are of the wedge variety and the quantity is so small that it would be hardly worth while to save them for scrap mica.

Biotite, which is not very abundant in any part of the quarry and is in some parts wholly absent, forms thin lath-shaped crystals averaging about 6 inches long, 1 inch wide, and a quarter of an inch thick.

Garnet is absent from much of the pegmatite, but is locally abundant in the finer-grained portions, occurring in crystals from onesixteenth to one-quarter of an inch in diameter. Very rarely crystals as much as 3 inches in diameter are found, and in these the garnet is, as a rule, graphically intergrown with quartz. The color varies from pink to deep red and opaque submetallic.

The area and form of this pegmatite body could not be determined because of the scarcity of outcrops in the vicinity of the quarry, but the occurrence of small masses of pegmatite of commercial grade short distances east and west of the quarry indicates that the deposit may have a considerable extension beyond the area now exposed.

The abundance of material now in sight and the freedom of most of it from iron-bearing minerals would favor further development. 


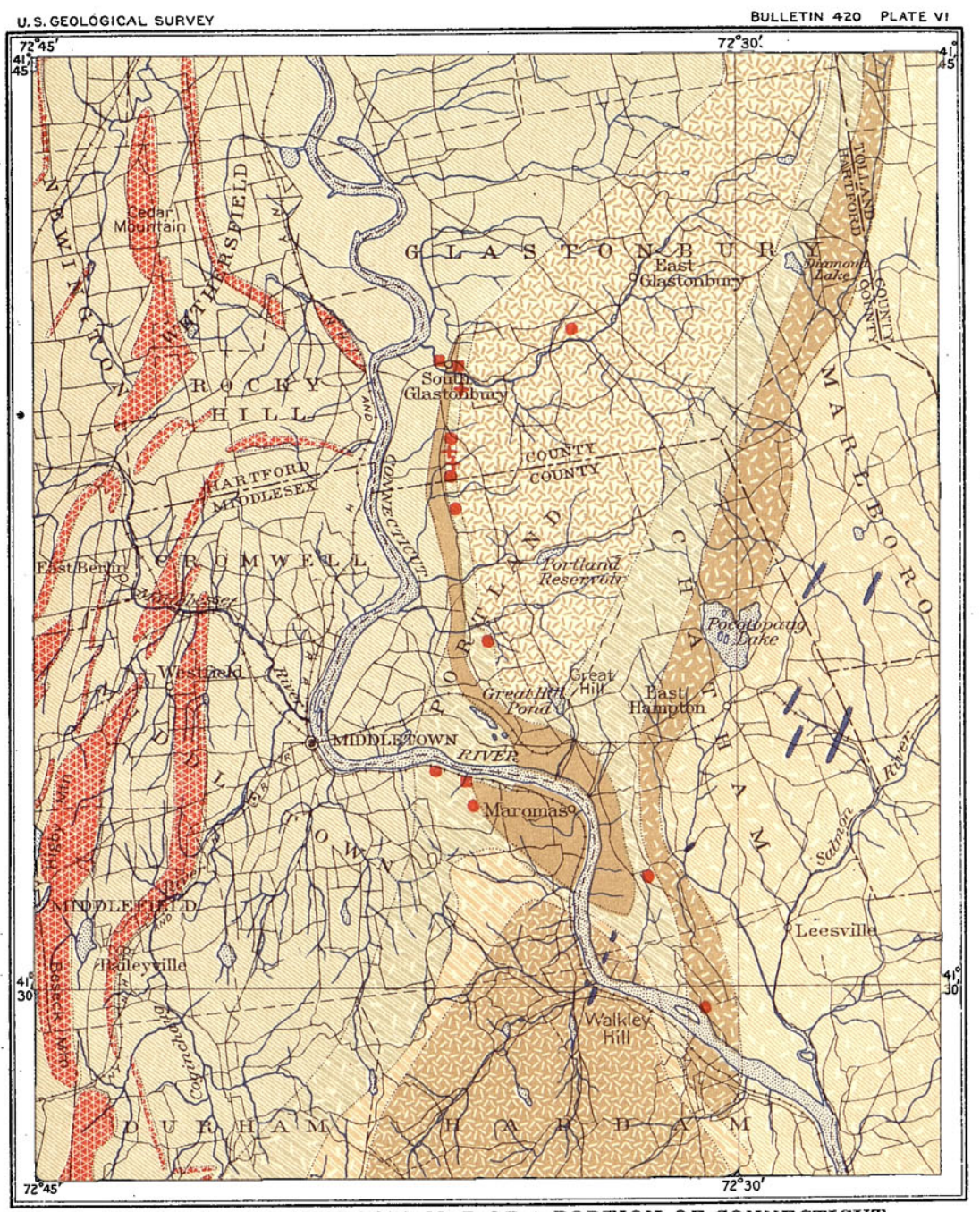

PRELIMINARY GEOLOGIC MAP OF A PORTION OF CONNECTICUT

Note: Geology taken from,

SHOWING LOCATIONS OF FELDSPAR QUARRIES AND MILLS Hist. Survey

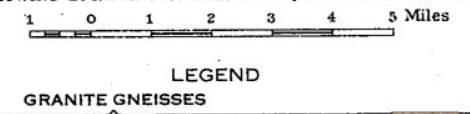

GRANITE GNEISSES

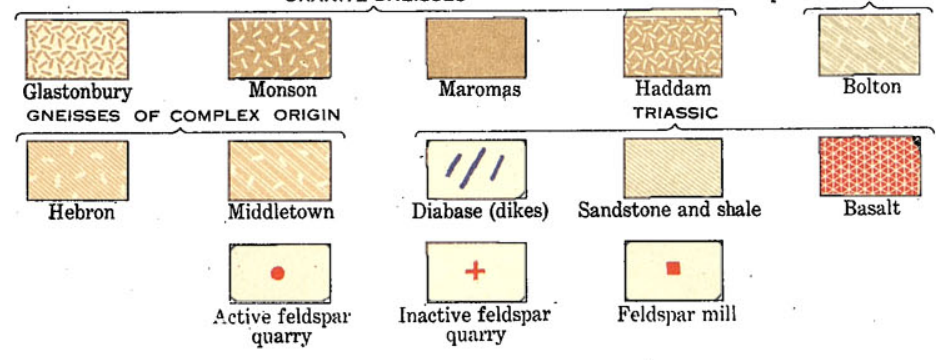





\section{MASSACHUSETTS.}

Small quantities of feldspar have recently been quarried by the Blandford Quarries Company, of Boston, near Blandford, in Hampden County, and shipped for grinding to Trenton, N. J. This property has not been visited by the writer.

\section{CONNECTICUT.}

\section{GENERAL STATEMENT.}

For many years Connecticut has ranked among the most important of the feldspar-producing States, and in 1908 it stood first in the value of the feldspar produced. In that year feldspar was obtained from eight quarries, all of them near Connecticut River in Middlesex County and in the southern part of Hartford County. There are three feldspar mills in the State, two at South Glastonbury and one at White Rocks, near Middletown. (See Pl. VI.) Much of the feldspar, however, is ground outside of the State, at Trenton and other pottery centers. All the active quarries and some that are now idle were visited by the writer in November, 1907, and are described below.

The geologic relations of the deposits are not fully known, but all are typical granite pegmatites and are believed to be intrusive in the bordering rocks. The Connecticut Valley pegmatites that are worked occur near the borders of large areas of granite gneiss mapped by the Connecticut Geological and Natural History Survey as Glastonbury granite gneiss and Haddam granite gneiss. It is highly probable that they are connected with one or both of these in origin. In Connecticut, as in other States, most of the pegmatite masses are more or less̃ lens-shaped and their longest diameter is, as a rule, parallel or nearly parallel with the trend of the bordering rocks. In at least one place, however, the pegmatite is a vertical dikelike mass cutting sharply across the foliation of the inclosing granite gneiss.

The form and size of the quarries vary greatly. All are open pits, and the largest one, the Howe quarry, 2 miles south of South Glastonbury, has a length of about 500 feet, an average width of 100 feet, and a maximum depth of 50 feet. From these dimensions the openings range downward in size to mere prospect pits. The feldspar from all these deposits is white to cream-colored potash feldspar (microcline or orthoclase) delicately intergrown with varying but minor amounts of soda feldspar (albite). Masses of pure feldspar more than 2 to 3 feet across seldom occur, and most of the material quarried is either a graphic or an irregular intergrowth of quartz and feldspar. From most of the quarries only one grade is shipped, which ranks commercially as No. 2, or "Standard." Quartz does not occur in commercial quantities at most of the feldspar quarries, 
and none is shipped. The quarrying processes are those commonly employed elsewhere.

Feldspar has been quarried at a number of places in the western part of the State - in Litchfield, New Haven, and Fairfield countiesand a feldspar mill was operated at Glenville, in Fairfield County. Microcline feldspar of good quality for pottery manufacture occurs associated with quartz in the quartz quarry of the Bridgeport Wood Finishing Company, near Southford, New Haven County, but is not saved in the mining.

\section{HARTFORD COUNTY.}

GLASTONBURY.

Roaring Brook quarry.-A small quarry one-half mile east of South Glastonbury, on the south side of the valley of Roaring Brook, was formerly worked by the Eureka Mining and Operating Company. It was visited by the writer in November, 1907. A small hillside opening shows granite-pegmatite intrusive in a gray to purplish mica schist, probably the Bolton schist of the Connecticut Geological Survey. The schist is rather flat-lying and the attitude of the pegmatite body is probably similar. The line between the pegmatite and schist is very sharp, and there is no. noticeable change in texture in either as the contact is approached. The constituents of the pegmatite show a slight tendency to lie in very uneven ; and not very noticeable bands, approximately parallel to the banding of the schists, this feature being most apparent in the quartz layers.

The quartz is opaque and milky white. The feldspar is buff microcline, finely intergrown with albite. It occurs in pure masses up to 3 feet across, some of which are characterized by very perfect crystal faces, though they were originally entirely inclosed by finergrained portions of the pegmatite. One of these feldspar crystals which has been partly uncovered during quarrying is shown in Plate $\mathrm{V}, A$, the crystal faces having been painted for photographing, so as to show up more clearly. The side or $b$ pinacoid is toward the front. The hammer rests on the third or $c$ pinacoid. This crystal shows strikingly the tendency of feldspar crystals in many pegmatites to develop perfect faces, even when they are entirely inclosed by other constituents. The pure feldspar of the crystal grades below into arborescent intergrowths of feldspar and quartz containing small muscovite plates. The crystal is bordered above by light-gray quartz and by muscovite "books," many of them 3 or 4 inches in diameter. Some of the muscovite plates lie perpendicular to the border of the feldspar crystal; others lie nearly parallel to it and curve around the crystal angles in a manner suggesting that they may have been somewhat deformed by the forces of crystal growth in the feldspar. Some of the muscovite "books" at this quarry 


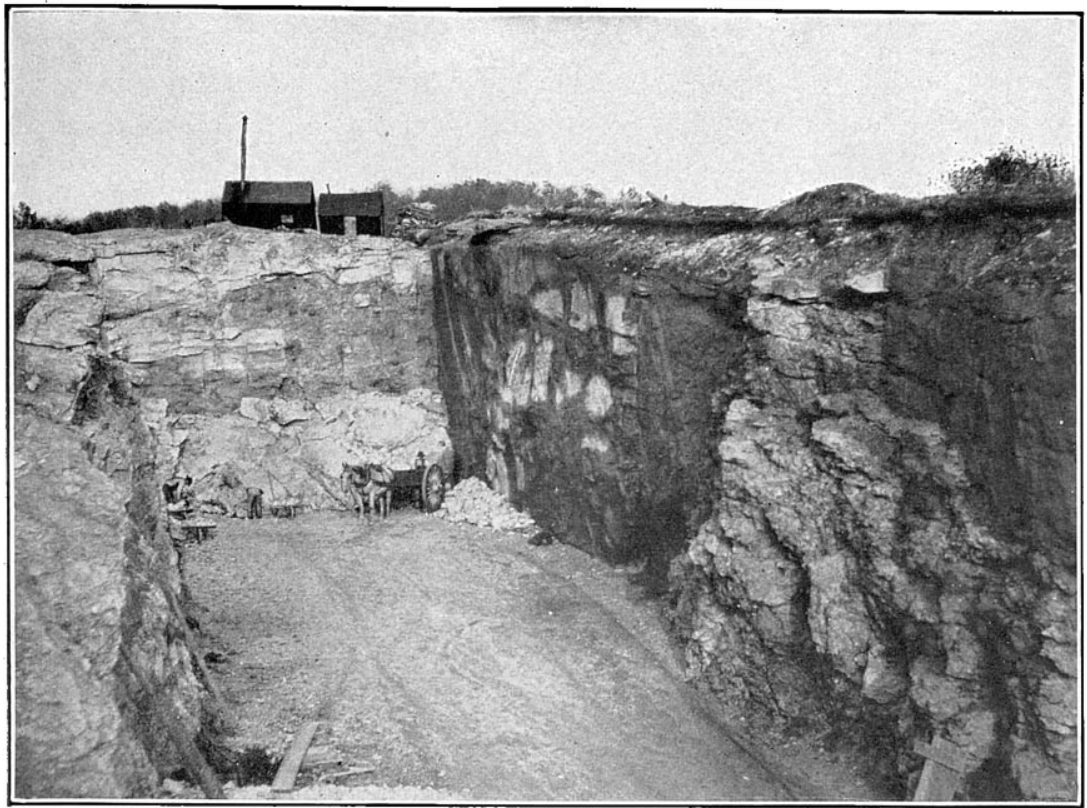

A. VERTICAL PEGMATITE DIKE INTRUDED ALONG FRACTURE PLANE IN GRANITE GNEISS AT FELDSPAR QUARRY NEAR EAST GLASTONBURY, CONN.

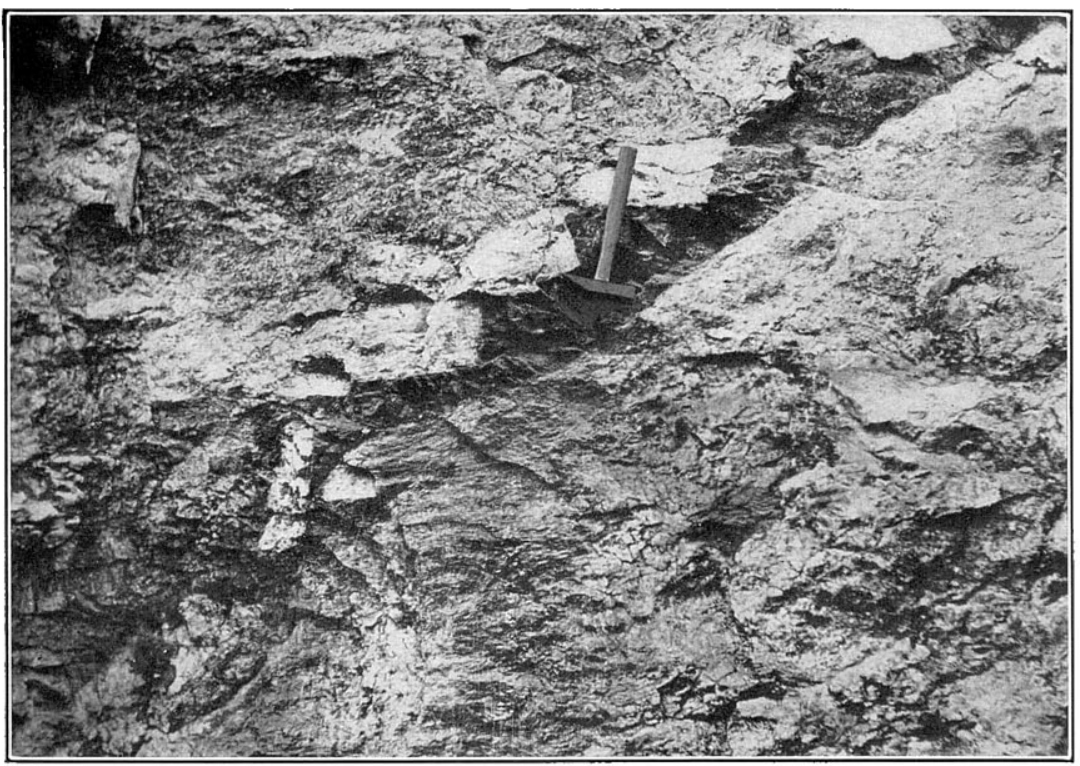

B. QUARTZ DIKE CUTTING PEGMATITE AT HOWE QUARRY, SOUTH GLASTONBURY, CONN. Showing light-colored feldspar crystals with well-developed crystal faces projecting into the quartz of the dike. The quartz appears dark colored in the photograph. 

are 6 . inches thick and 4 to 6 inches wide. Nearly all are characterized by close ruling and crumpling and are not of commercial value except for ground mica. The fracture planes known as ruling are so closely spaced in some places that the mica near them is reduced to an aggregate of long fibers. Small folds in the mica pass at many places into planes of ruling. These therefore-some of them at least-represent a yielding to deformation. Biotite is present only rarely and in small plates or aggregates. Garnet is abundant in the finer-grained portions of the pegmatite and renders much of the material valueless for pottery purposes.

The amount of feldspar of pottery grade at this locality appears to be small and the quarry was very properly abandoned.

East Glastonbury quarry.-A feldspar quarry $2 \frac{1}{2}$ miles northeast of South Glastonbury, near the road to East Glastonbury, is worked by a firm that uses the product entirely in the manufacture of abrasive soaps. This quarry is on the farm of Frank G. Curtis and consists of a single pit about 250 feet long, trending northeast and southwest. It is about 30 feet wide at the northeast end and narrows to 15 feet at the southwest end, having an average depth of about 20 feet.

The bordering rock, a biotite granite gneiss, is well exposed at the quarry. The pegmatite forms a nearly vertical dike which cuts across the trend of the gneiss. (See Pl. VII, A.) The metamorphic effects of the pegmatite on the gneiss have been so slight that the contacts are of knife-edge sharpness, the delicate foliation of the gneiss being perfectly preserved quite to the contact with the pegmatite. At the small granite quarry about one-fourth mile from the feldspar quarry pegmatite dikes up to a foot in diameter cut sharply across the folia of the granite gneiss without evidence of contact metamorphism. The main pegmatite mass at the feldspar quarry shows absolutely no change in texture near the walls. It sends off into the bordering granite gneiss a number of small branches, which also show little change in texture near their walls, though in some there is a slight increase in the amount of quartz next the walls and near the ends of the branches.

The rock at this quarry is typical granite pegmatite showing some masses of pure feldspar $2 \frac{1}{2}$ to 3 feet across. Most of the feldspar is cream-colored microcline finely intergrown with small amounts of albite. Graphic granite is almost entirely absent, but the microcline and also white albite are irregularly intergrown with quartz. Quartz is not present in pure large masses and is not of commercial importance.

Muscovite is next to quartz in abundance. A few of the "books" are 5 to 6 inches across, but most of them are under 3 inches. All 
show wedge structure, ruling, or twinning, and are therefore of value only for ground mica.

Red garnets are abundant in certain of the finer portions of the rock, and as a rule occur in streaks or zones. Few of the crystals are over one-eighth inch in diameter.

Surface outcrops show that the pegmatite dike extends northeastward somewhat beyond the wagon road. Its width at the wagon road is over 80 feet, and some of the pegmatite exposed at the roadside is of excellent quality. The dike can be traced for over 100 yards northeast of the road, and feldspar of commercial grade outcrops beyond the house of James H. Cox. It is therefore probable that the vein can be worked for some distance along its trend beyond the present workings, and it is also practically certain that it continues downward to considerable depths.

The material is quarried by steam drilling and blasting and is hauled by two-horse and four-horse teams 9 miles to the mill at North Manchester. Here it is crushed, first in a rotary crusher, then in a chaser, and is ground to requisite fineness in tube mills. Only the purest portions of the pegmatite are used, and the amount of quartz in the ground product will probably not exceed 10 per cent.

John C. Wiarda quarry.-John C. Wiarda \& Co. operate a small feldspar quarry about $1 \frac{1}{4}$ miles south of South Glastonbury, in the same belt with the Howe quarry and the quarries formerly operated by the Eureka Mining and Operating Company. The largest pit is about 40 by 60 feet and is 15 feet in maximum depth. The rock is granite pegmatite, not very coarse, and seldom showing feldspar crystals more than 6 to 10 inches across. The quartz is light gray to dark gray in color and is not present in commercial quantities. Most of the material shipped is an irregular intergrowth of feldspar and quartz, though small amounts of graphic granite also occur. The feldspar is white to cream-colored microcline intergrown with small amounts of albite. No plates of muscovite larger than 3 inches across were observed, and all the muscovite is much affected by ruling and crumpling. Some is graphically intergrown with quartz. Some parts of this pegmatite are very fine grained, and these contain abundant biotite, most of it in radially arranged crystals.

A new pit about 100 feet northeast of the one described above is just being opened, and exposes a small mass of gray granite gneiss in which the pegmatite is plainly intrusive. In both pits a vague banding is produced by an alternation of finer and coarser portions. In the southern pit this banding trends about N. $30^{\circ} \mathrm{E}$. and dips about $40^{\circ}$ to the northwest. In the northern pit it has a similar trend, but dips about $60^{\circ}$ to the northwest. It is probable that this banding indicates in a general way the trend of the deposit. 
The pegmatite can be traced N. $25^{\circ} \mathrm{E}$. for some distance beyond the present workings, but its quality is rather uncertain. The material is worked by steam drilling and blasting and is hauled by teams $1 \frac{1}{4}$ miles to the mill of the company at South Glastonbury.

John C. Wiarda feldspar mill.-This mill, at South Glastonbury, is equipped with one chaser for crushing the feldspar and three smallsized tube mills. The capacity of the mill is said to be about 15 tons in twelve hours. A considerable amount of the material produced by this firm is used in glass manufacture and enamel ware. From the mill the material is hauled 1 mile to Connecticut River, then ferried across to Rocky Hill and shipped by rail.

Two quarries formerly, worked by the Eureka Mining and Operating Company but not operated at the time of the writer's visit, in November, 1907, are located in the town of Glastonbury, about one-half mile north of the Howe quarry, described below. These consist of two pits on a western hill slope lýing about 100 feet apart on a northsouth line. The southernmost one is 100 feet by 40 feet in horizontal dimensions and 30 feet in maximum depth. The rock is granite pegmatite, similar to that quarried at the Howe quarry. A considerable amount of feldspar was piled in stock piles at these quaries at the time of the writer's visit, and there still appears to be an important amount of material of pottery grade available.

Howe quarry.-This quarry is about 2 miles south of South Glastonbury, a short distance east of the Portland road and close to the Hartford-Middlesex County line. It is operated by Lewis W. Howe, of South Glastonbury, and is the largest feldspar quarry in Connecticut as well as the oldest, having been worked for over forty years. The principal pit trends in general about N. $5^{\circ} \mathrm{E}$. and is 500 feet long, 100 feet in average width, and has an average depth of about 50 feet, though the eastern wall is considerably higher than the western. The rock is typical granite-pegmatite, which is cut by a number of small quartz veins, one of them traceable continuously for 100 feet. The largest vein becomes locally 2 feet wide, and from this tapers in width to 3 inches. These veins are plainly contemporaneous with the pegmatite, for feldspar crystals continuous with the bordering pegmatite project into the quartz of the veins with well-developed crystal faces, as shown in Plate VII, $B$. The particular dike here figured was traceable from the bottom of the quarry upward for about 30 feet to a point where it pinched out. Its width varies from 3 to 8 inches.

The feldspar of this quarry is white microcline intergrown with small amounts of albite. It seldom occurs in pure masses more than 3 feet across, the bulk of the material shipped being an irregular or graphic intergrowth of quartz and feldspar. 
In the highly feldspathic parts of the pegmatite muscovite is only rarely present and is usually in small plates, often graphically intergrown with the quartz. The largest mica "books" seen were not more than 5 inches across and showed wedge structure, crumpling, or ruling. None of the mica is of commercial quality. Biotite is present only here and there. It occurs in small crystals in the finergrained portions of the pegmatite, its mode of occurrence being in every way similar to that at the Wiarda quarry. In a few places there are red garnets up to an inch in diameter, but muscovite, garnet, and dark quartz occur principally in certain irregular areas, and can readily be separated from the better material in mining.

Black tourmaline is present, but none of the crystals observed were more than one-half inch in diameter. Occasionally it is present in granular masses of minute crystals that form veins, one-sixteenth to one-fourth of an inch wide, traversing the pegmatite. These are probably the result of pneumatolytic action subsequent to the solidification of most of the deposit.

The wall rock is exposed at the south end of the pit, where the pegmatite is seen to be intrusive in a purplish to grayish quartzmiea schist, probably the Bolton schist of the Connecticut Geological Survey. The schist strikes about north and south and dips about $30^{\circ}$ to the west. The pegmatite cuts across the folia of the schist at a low angle. The east wall of the quarry is of pegmatite, most of it too quartzose or too garnetiferous to be of commercial value. All the best feldspar has been found in the western part of the mass and there appears still to be a considerable amount of commercial material in the west wall. The deposit can be traced for 100 feet north of the present workings and probably extends much farther. To the south it probably continues for at least 150 feet beyond the present pit, to a point where the hill slope descends abruptly. Much spar of excellent grade is exposed also on the floor of the quarry, so there is every reason to believe that this quarry will not be exhausted for many years to come.

The hillside position of the quarry permits wagons to be driven directly into the pit for loading. The excavating is done by steam drilling and blasting, and the spar is hauled $2 \frac{1}{4}$ miles to the mill of Mr. Howe, at South Glastonbury.

Howe mill.-The Howe mill, at South Glastonbury, is operated during part of the year by water power of Roaring Brook and during the remainder of the year by steam power. Its capacity is said to average about 27 tons in twelve hours. The equipment includes 2 chaser mills and 5 tube mills, each 7 feet in diameter and 5 feet long. The ground spar is shipped in bulk or in bags and is hauled from the mill 1 mile to Connecticut River and ferried across to Rocky Hill, where it is shipped by rail. 


\section{MODDLESEX COUNTY.}

CHATHAM.

Eureka Mining and Operating Company's quarry.-A small quarry operated by this company is located about $1 \frac{1}{2}$ miles southeast of Middle Haddam. The quarry had been worked only a short time when the writer visited it, in November, 1907. It consisted of a single pit on a northeast hillside. The breast opened here is about 50 feet high and 40 feet wide. The rock is a typical granite pegmatite. Quartz does not occur in masses large enough to be commercially valuable. The feldspar is cream-colored orthoclase and microcline, finely intergrown with small amounts of albite. It seldom occurs in pure masses more than 2 feet across, the commericial product being principally graphic granite.

Muscovite occurs in "books," most of them 4 to 5 inches, but some of them 8 inches across, and shows wedge structure and ruling, none of it being of commercial grade except for grinding. It also occurs in flat intergrowths with quartz, some of which are one-fourth inch to one-half inch thick and 2 feet across.

Biotite occurs in crystals, some of them 3 to 4 inches across, and is frequently inclosed by muscovite in parallel intergrowth. Black tourmaline is also moderately abundant, the largest crystal observed being 3 inches in diameter. Some is in graphic intergrowth with quartz.

Pockets or cavities are irregularly distributed through this pegmatite. The largest are 7 or 8 inches in diameter, and some of them, especially the smaller ones, contain tourmalines of gem quality. In color these are usually grass to olive green, and many show very perfect terminations. Some are of the variety achroite, being colorless or very pale green or pink. Near the pockets opaque or translucent green tourmalines, granular aggregates of lepidolite, and muscovite bordered by lepidolite or in parallel intergrowth with it, are common. The gem tourmalines are, as a rule, found lying in sandlike matrices at the bottoms of the pockets.

The rocks bordering this pegmatite are mica schists, probably the Bolton schist of the Connecticut Geological Survey, which strikes N. $25^{\circ} \mathrm{W}$. The pegmatite, which constitutes practically the whole of the ridge in which the quarry is located, appears to be a dikelike mass whose greatest length is about parallel to the trend of the schist. The natural exposures on the summit of this ridge and on the western slope show considerable amounts of feldspar of pottery grade, some pure feldspar crystals being 3 feet across. The width of the ridge appears to be about 150 feet. Quarrying is done in the usual manner, and the spar is hauled by teams about $1 \frac{1}{4}$ miles to Connecticut River, where it is shipped to Trenton, N. J., in barges. 
HADDAM.

Haddam Neck quarry.-One of the oldest feldspar quarries in Connecticut, and one which is well known for the gem tourmalines and fine mineral specimens it has yielded, is located on the east bank of Connecticut River about opposite Haddam village. A ferry crosses at this point. The property was visited by the writer in November, 1907.

The quarry consists of two pits located about 100 yards east of the river bank. The western one was worked mainly for its tourmalines and mineral specimens and is now abandoned. It is 50 to 60 feet in length from north to south and about 40 feet in width, and is partly filled with water. According to Mr. John C. Wilkes, the superintendent of the quarry, some of the cavities that yielded gem tourmalines in this pit were as large as a bushel basket. The opening now being worked lies just east of the old pit and is separated from it by a 20 -foot wall of schist and pegmatite. It is 300 feet long from north to south, 100 feet in maximum width, and 40 feet in average depth.

The rock at the pit now worked is a granite pegmatite, but in addition to the minerals usually present in such deposits contains many others that are characteristic of gem-bearing pegmatites, and also contains numerous cavities or pockets in which occur tourmalines of the best quality. Most of these minerals have been described by H. L. Bowman. ${ }^{a}$

Quartz is not present in pure masses large enough to be commercially important. The feldspar is buff orthoclase and microcline, finely intergrown with small amounts of albite. No masses of pure feldspar more than 3 feet across were observed, and masses of this size are said to be rare. Most of the material shipped is a graphic or irregular intergrowth of feldspar and quartz. The feldspar near some of the pockets is very pale green albite. Muscovite occurs in "books," some of which are a foot in diameter and 5 to 8 inches thick. Some "books" 2 feet across have been reported. Nearly all are affected by ruling and wedge structure, though a few would cut good clear pieces 2 by 3 inches in size. The mica here and there becomes more abundant within 2 or 3 feet of some of the schist walls. Several tons of mica are piled at the quarry but none has been marketed.

Crystals of dark red fluorite under an inch in size are occasionally found, as is also columbite.

The principal iron-bearing mineral is black tourmaline, which is very abundant in certain parts of the pegmatite. Its distribution is usually irregular, but in one place it is particularly abundant in a

$a$ Min. Mag. and Jour. Min. Soc. London, vol. 13, pp. 97-121, 4 figs. Reviewed in Mineral Resources U.S. for 1902, U. S. Geol. Survey, pp. 841-842. 
band 1 to 2 inches thick and 5 feet long. In many places it penetrates mica "books."

The pockets or cavities which oecur in the eastern pit and which carry the gem tourmalines average 8 or 10 inches in diameter, though there are many smaller ones only 2 to 3 inches across. They are distributed with great irregularity through the pegmatite mass. Lepidolite in finely granular masses, pale green albite, and small green tourmalines are abundant near many of the pockets. Muscovite surrounded by a border of lepidolite, or in parallel growth with lepidolite, is also of common occurrence near the pockets. As in most of the gem-bearing pegmatites the tourmalines are seldom in their original positions on the walls of the cavities, but lie embedded in a sand-like mass of quartz fragments, cookeite, and other decomposition products at the bottom of the pockets. They are mainly grass green to olive green in color, becoming nearly colorless toward the tip. The exact apex of some of the crystals is pink and many of them show very perfect terminations. Gem. tourmalines are not so abundant that it would pay to work the mine for these alone. Those encountered in the feldspar mining are marketed irregularly through local collectors.

The schists bordering the pegmatite at this locality are nearly vertical and trend north and south. Their contact with the pegmatite is absolutely sharp. They are gray to purplish muscovitebiotite schists, probably of sedimentary origin and belonging to the Bolton schist of the Connecticut Geological Survey. They are lithologically similar to those at the Roaring Brook quarry of this company. The pegmatite mass for the most part is elongate parallel to the trend of the schists, though locally cutting across them. Considerable amounts of commercial material seem still to be available. There is an overburden of sands and gravels, which in places attains a thickness of 10 feet. The feldspar is quarried in the usual way, by simple drilling and blasting, and is loaded into barges for shipment by water to the mill of this company at Trenton, N. J.

MIDDLETOWN.

Consolidated Feldrpa Company.-This company has a quarry at White Rocks, 3 miles east of Middletown, at an elevation of nearly 500 feet. At the time of the writer's visit, in November, 1908, the quarry consisted of a single open pit on a north hillside and had not been extensively worked. The rock is typical granite-pegmatite and contains no masses of pure quartz that are large enough to be of commercial value. The feldspar is cream-colored microcline, in most places finely intergrown with small amounts of albite. Muscovite occurs in crystals 3 to 5 inches across and from 2 to 3 inches 16779-Bull. $420-10-4$ 
thick, but is rendered worthless by the presence of ruling and wedge ctructure. The principal iron-bearing mineral is biotite, which occurs in lath-shaped crystals 1 to 2 inches wide, and is very abundant in some parts of the pegmatite. Black tourmaline is rare. The ledge that is now being worked and a number of others. on this property contain considerable amounts of feldspar of pottery grade.

The material is taken by tramway downhill for about half a mile to the mill, which is at the side of the railroad and also within a few rods of Connecticut River, so that shipments may be made by water if desired. The mill is equipped with a gyratory crusher, crushing rolls, rotary drier, and two tube mills, 18 by 6 feet, whose capacity is stated to be 30 tons in ten hours. It is the purpose of this company to use the better grade of material for pottery purposes and to crush the remainder for use as poultry grit and in the manufacture of ready roofing. Power is furnished by a gas engine and gas producer.

Riverside quarry.-A small quarry about a mile northeast of the one just described was operated in 1907 by L. T. Snow, of New Haven, but work was suspended in 1908. The quarry consists of a single open pit on a northwest hill slope. The pegmatite is similar to that at the quarry above described and much of it appears to be of excellent quality for pottery purposes. Some masses of pure feldspar are 2 to 3 feet across, and pegmatite of good quality is traceable for at least 300 feet southeastward from the present quarry. Both biotite and black tourmaline are present but are not abundant. Other minerals are light-green translucent beryls (in one specimen the beryl crystal was penetrated by a crystal of black tourmaline) and pink to deep salmon-colored fluorite.

The White Rocks region is in general one of the most promising known to the writer for quarrying the best grades of feldspar. Aside from that at the two quarries described, feldspar of good quality was observed at several localities near the wagon road north of White Rocks. The situation is also favorable for cheap quarrying and shipment.

\section{PORTLAND.}

Andrews quarry.-This quarry is about $2 \frac{1}{2}$ miles south of South Glastonbury, near the road to Portland, and is about one-half mile south of the Middlesex-Hartford county line. It consists of two open pits at the north end of a ridge trending nearly north and south, a lower northern pit 150 feet long, 30 to 50 feet wide, and 50 feet deep, and an upper pit immediately to the south and 50 feet above the floor of the lower one. The breast at the upper pit is abput 70 feet wide and 25 feet in maximum height, and from this breast feldspar that appears to be of good grade for pottery was 
traced southward along the sides of the ridge for more than 600 feet to a place where the slope descends sharply to the south.

The rock is a typical granite-pegmatite. The quartz is light gray to white and is not present in masses large enough to be commercially valuable. The feldspar is principally of the potash variety (microcline), finely intergrown with small amounts of albite, and seldom occurs in pure crystals more than 2 to 3 feet across. The bulk of the material quarried is graphic granite, most of it rather coarse, containing here ant there small crystals of pale-green microcline. Locally the graphic granite becomes very fine grained. An analysis of this material is given in the table on page 14 (analysis No. 4). In some places the very fine grained pegmatite is banded, the darker bands being rich in muscovite and containing some garnet and black tourmaline, and the lighter bands consisting mainly of quartz, microcline, and albite.

Muscovite is the mineral next in abundance to the quartz and feldspar. Most of the crystals are under 3 inches in diameter and are not of commercial quality except for ground mica. The muscovite is in places intergrown graphically with quartz.

The garnets present are all very small, few of them more than one-sixteenth of an inch in diameter. They are abundant in some of the fine-grained portions of the pegmatite, but rare in the coarser, commercial portions. On decomposing, they produce brown stains.

Black tourmaline is entirely absent from most of the deposit, though it occurs in curved bands of small crystals at the north end of the lower pit and at a small test pit one-fourth of a mile south of the present workings.

Biotite occurs only scantily and in very small plates.

The rocks bordering the pegmatite are nowhere exposed in the vicinity of this quarry, but the pegmatite mass seems to have a northand-south trend, the same as that of the ridge on which it occurs. The deposit differs from all others with which the writer is familiar in the unusual scarcity of all iron-bearing minerals, and for this reason is of uncommonly good quality for the manufacture of pottery, the amount of waste material in the quarrying process being smaller than at most quarries. A large amount of commercial feldspar is still available at this place.

The situation of the quarry. on a steep hill slope is favorable for economical working. Steam drills are employed. Some of the spar is hauled 2 miles to Connecticut River for shipment by water; some is hauled 3 miles and ferried across the river to Rock Hill, where it is shipped by rail, and some is hauled $2 \frac{1}{2}$ miles to the mill of John C. Wiarda \& Co., at South Glastonbury.

Eureka feldspar quarry.-A feldspar quarry operated by the Eureka Mining and Operating Company of Trenton, N. J., is located about 
$2 \frac{1}{2}$ miles northwest of Portland, on the west slope of Collins Hill. The quarry was visited by the writer in November, 1907, and at that time the working extended along the hillside for about 100 feet, but was not excavated to any considerable depth. The rock is a granite pegmatite. The quartz is mostly white or light gray, but occurs occasionally in transparent, pale amber-colored masses several feet across. It would probably be profitable to save it in the mining. The feldspar is white to cream colored, and is an intergrowth of microcline with a small amount of albite. Most of the masses 'of clear feldspar are less than 3 feet across. The principal commercial product is a graphic or irregular intergrowth of quartz and feldspar.

Some of the muscovite plates are 8 or 9 inches in diameter, but nearly all show ruling and wedge structure.

Biotite is almost entirely absent.

Black tourmaline is moderately abundant, and one crystal 4 inches in diameter was seen. Some of the tourmaline crystals show almost perfect terminations. Smaller crystals are frequently found penetrating muscovite.

Small black or dark-red garnets occur in the finer-grained portions of the pegmatite.

Pockets or cavities are ocoasionally encountered, their distribution being entirely irregular. The largest one found is said to have measured 4 feet by $1 \frac{1}{2}$ feet by $1 \frac{1}{2}$ feet, and it yielded a large transparent green tourmaline about 7 inches long, which is now in the museum of Wesleyan University at Middletown. Most of the gem tourmalines found in the pockets are transparent grass-green to olive-green. A single pocket, however, contained a large crystal weighing several pounds, of pale-blue to pale-green color, the tints being similar to those observed in some aquamarines. Unfortunately, this crystal was completely shattered in the blasting, but the fragments have yielded a number of small cut gems of great beauty. Near the pockets granular lepidolite, white albite of the clevelandite variety, and opaque yellowish green beryl crystals up to 8 inches in diameter occur, and many of these are penetrated by black tourmaline and light-gray quartz.

Columbite is occasionally found, the largest piece being about $2 \frac{1}{2}$ by $1 \frac{1}{2}$ by 1 inch in size and showing good crystal faces.

The bordering rock is exposed on the northeast wall of the pit and is a muscovite-biotite schist much contorted, probably the Bolton schist of the Connecticut Geological Survey. The trend is somewhat variable, but is generally about north and south. The pegmatite mass now being worked appears to wedge out about 100 to 150 feet southeast of the present working. The crest of the hill east of the pit is occupied principally by schist, which shows some pegmatite of commercial grade. The latter cuts directly and sharply 
across the foliation of the schist, and neither show any perceptible change as the contact is approached.

The quarrying is done by steam drilling and blasting, and about fifteen men are employed. The spar is hauled by teams about 2 miles to Connecticut River, and shipped by barge to Trenton, N. J.

\section{NEW HAVEN COUNTY.}

Southford quarry.-About $1 \frac{3}{4}$ miles south of Southford station is a quarry which is worked by the Bridgeport Wood Finishing Company for quartz but which contains considerable quantities of feldspar of pottery grade. The quarry is an open pit about 200 feet long from northeast to southwest, about 100 feet in maximum width, and 40 feet in average depth.

The rock is a granite-pegmatite, richer in quartz than in most quarries where feldspar is mined. At the southwest end of the quarry the material is largely quartz, mainly white, but there are masses of pale-rose color irregularly distributed through the white quartz. Some portions are translucent and milky; other portions are banded, the banding being due to the presence of numerous fluid inclusions. Some of the masses of pure quartz are 30 feet across.

The color of the feldspar ranges from buff to pink, even in the same crystal. The feldspar near the large quartz areas usually shows well-developed crystal faces.' The percentage of feldspar increases toward the north end of the quarry. It is in some places irregularly or graphically intergrown with quartz. A peculiar phase of this pegmatite is the presence, especially between large masses of pure quartz, of very fine grained sugary aggregates, composed principally of small grains of orthoclase feldspar, with small muscovite plates oriented in every direction and bands of small garnets. Material of this type occurs in masses up to 3 to 4 feet across, and goes to pieces rapidly when exposed to the weather.

Muscovite is abundant and occurs mainly in bladelike or spearhead-shaped "books" arranged with their long axes at right angles to the quartz-feldspar contact planes, though the muscovite plates are usually inclosed by the feldspar rather than the quartz. Some of the blades are 6 inches across and $1 \frac{1}{2}$ feet long. Muscovite also occurs in graphic intergrowth with quartz and also forms more or less rounded aggregates of small muscovite plates oriented in every direction, the interspaces being filled with feldspar. Wedge structure and ruling characterize most of the muscovite, and none is of commercial value except for ground mica.

Black tourmaline occurs in graphic intergrowth with quartz. Wine-red garnets of all sizes up to one-half inch (though most of them are smaller) are specially abundant in the fine-grained, sugary phases of the pegmatite. Beryl, opaque and of blue-green color, is moder- 
ately abundant. One crystal on the waste pile was 2 feet long and $1 \frac{1}{2}$ feet in diameter. A few show an approach to gem quality. Chalcopyrite is occasionally found in pieces an inch or so in diameter, as is also one of the sulphides of bismuth and lead in intergrowth with small muscovite plates.

Exposures of the bordering rocks are rare in this vicinity. An outcrop of granite gneiss occurs about 100 yards south of the quarry, but the walls of the quarry are all in pegmatite, and it is not possible to determine the trend of the deposit. There is, however, no indication of its immediate pinching out. An overburden of till, which in places is as much as 12 feet in thickness, must be stripped in quarrying. The quarry is equipped with steam drills, steam pump, derrick, hoisting engine, and teams for hauling the quartz $1 \frac{3}{4}$ miles to the railroad station at Southford. The quarry employs about six men. The feldspar could certainly be handled at a profit in connection with the quartz mining.

\section{NEW YORK.}

The feldspar quarries of New York are in Westchester County (in the southeastern part of the State) and in the Adirondack region. Those in Westchester County produce feldspar that is used only for fine grinding for the pottery, glass, and enamel-ware trades. In the Adirondack region feldspar for these uses is also produced, but in addition considerable quantities of pegmatite are crushed and sized for use as poultry grit and in the manufacture of ready roofing.. All the deposits of the northern region are probably of pre-Cambrian age and occur near the border of the large Adirondack area of preCambrian rocks. The details of their geologic relations are not known. The deposits of the southern region may be as late as Silurian. Their geologic occurrence is described farther on.

\section{ESSEX COUNTY.}

\section{CROWN POINT.}

A feldspar mill operated by the Crown Point Feldspar Company is located on the Delaware and Hudson Railway about $1 \frac{1}{4}$ miles south of Crown Point station. This company became an aetive producer in 1908. The quarry is about a mile southwest of the mill.

The quarry is a large open pit near the summit of the north slope of Dibble Mountain. It is about 150 feet long and 150 feet wide and exposes a breast of pegmatite 50 feet high. The rock is a typical granite-pegmatite. Most of the quartz is gray, but some of it is pale rose colored. It occurs in pure masses, some of them 3 or 4 feet across The potash feldspar is of two varieties, pale pink to flesh-colored microcline and gray microcline. The gray variety, which occurs in graphic intergrowths with quartz, furnishes the bulk of the material 
that is ground for the manufacture of enamel ware. Some masses of graphic granite about 5 feet across are wholly free from ironbearing impurities. Soda-lime feldspar (oligoclase) of pale-green color is associated with the pink microcline and is about half as abundant.

Biotite, the principal iron-bearing mineral, occurs in thin, irregular plates, most of them only a few inches across, and as a rule aggregated. Black tourmaline occurs sparingly, though some crystals are 2 inches in diameter. No transparent tourmalines have been found. Very perfect crystals of zircon about half an inch in length are abundant in a few places in close proximity to a black, anthracite-looking mineral which is veinlike and forking in form, but which is probably a thin crystal. Its maximum thickness is about $1 \frac{1}{2}$ inches and its length several feet. Careful tests show it to be allanite, a silicate of iron, calcium, aluminum, and the rare metals of the cerium group. No beryl or garnet was observed.

The pegmatite at this quarry is excavated by steam drilling and blasting and loaded on tram cars. The buckets of the cars, which hold about 500 pounds, are transferred directly to a wire cableway that carries the pegmatite to the mill, over a mile distant.

At the mill the pegmatite is first crushed in a Blake crusher (it is planned to install a gyratory crusher), and the feldspar to be used in the manufacture of enamel ware is then crushed in a chaser mill and finally ground in two small tube mills ( 7 by 8 feet), with a capacity of 2 to $2 \frac{1}{2}$ tons in five hours. The pegmatite prepared for poultry grit and for roofing purposes passes from the Blake crusher to a series of crushing rolls and Newago screens, which reduce it to the various sizes desired. The mill is on the railroad, and the product can be loaded directly onto the cars. It is also within a few yards of the shore of Lake Champlain, and on the completion of the Hudson and Champlain Barge Canal water shipment will also be possible.

TICONDEROGA.

Pegmatite mine of Barrett Manufacturing Company.-The quarry and mill of this company are $1 \frac{3}{4}$ miles northwest of the railroad at Ticonderoga. The quarry, an open pit near the eastern base of a hill, is about 300 feet long from northeast to southwest and 150 feet in average width. Its maximum depth is about 35 feet and the average about 20 feet.

The rock is typical granite-pegmatite. Gray quartz occurs intergrown with other minerals, rarely in pure masses more than a few inches across. The most abundant feldspar is pearl-gray potash feldspar (microcline), which seldom forms crystals more than 6 inches across. About one-fourth as abundant as the gray microcline is a light-green soda-lime feldspar (oligoclase), similar to that found at 
the quarry of the Crown Point Feldspar Company. Graphic granite is abundant. Biotite, the principal iron-bearing mineral, is scattered very irregularly and abundantly through the rock, some of the crystals being 8 inches wide, 2 feet long, and one-fourth to one-half inch thick. Black tourmaline is occasionally found in very perfect graphic intergrowths with quartz. Garnets are rare.

The rocks bordering the pegmatite are exposed on both the east and west walls of the pit and are garnetiferous schists which strike N. $55^{\circ}$ to $60^{\circ} \mathrm{E}$. and dip $35^{\circ}$ or $40^{\circ} \mathrm{SE}$.

The excavating is done by steam drills, and the pegmatite is hauled in tram cars to the mill, a few yards distant. Here it goes to storage bins, then successively to a Blake crusher, to 20-inch crushing rolls, and to Jeffrey vibrating screens, which screen it to the various sizes desired. All the product is used in the manufacture of ready roofing material, for poultry grit, as facings for cement blocks, etc. None is of pottery grade. The crushed and sized product is hauled by wagon $1 \frac{3}{4}$ miles to the railroad at Ticonderoga.

Ticonderoga Feldspar Company.-A small quarry has been opened by this company about a mile southeast of Ticonderoga. The material is not typical pegmatite, but is a coarse-grained hornblende granite which locally becomes slightly pegmatitic. It is intrusive in impure gray limestone. The quarry is a single opening on an eastern hillside and shows a breast 60 feet high. A small mill has been erected at the mine, equipped with Blake crusher and vibratory screen. At the time of the writer's visit, in April, 1909, the quarry had not been operated for several years.

\section{FULTON COUNTY.}

A feldspar quarry recently opened by the Claspka Mining Company, of Trenton, N. J., is located in the northeast portion of Fulton County, about $6 \frac{1}{2}$ miles south-southwest of Northville. It is on lot 4, subdivision 1 of the Glen Bleeker and Lansing patent.

The working consists of a single pit, 25 to 30 feet wide, on a southwest hill slope. The maximum depth of the pit is 40 or 50 feet. The rock is a typical granite pegmatite. White to light-gray quartz occurs in pure masses up to 4 or 5 feet across. The principal feldspar is pale-pink potash feldspar (microcline), finely intergrown with a soda feldspar, probably albite. Greenish-gray crystals of soda-lime feldspar (oligoclase), many of them 6 or 8 inches across, are abundant, 'so that the pegmatite as a whole is more sodic than most granite-pegmatites and will yield a slightly "softer" or more fusible spar. The difference in fusibility, however, will probably not be important commercially. The largest pure feldspar masses seen were 4 to 5 feet across. Some graphic granite, most of it coarse, is present. 
The principal iron-bearing impurity is somewhat altered biotite, which occurs in "books," many of them 6 to 8 inches across and 6 inches thick. The largest biotite mass seen was a flat crystal $1 \frac{1}{2}$ feet wide and 3 feet long. Very subordinate amounts of black tourmaline are present in intergrowth with quartz.

The pegmatite at this quarry is cut by a vertical trap dike 40 to 50 feet wide, striking about N. $35^{\circ} \mathrm{E}$. The pegmatite mass can be traced northwestward along the hillside for about 100 feet from this dike and for an equal distance southeast of the dike. Pegmatite is exposed on the hill slope for more than 50 feet above the bottom of the quarry pit. The rocks associated with the pegmatites in this vicinity are schists and granite gneisses. A short distance south of pit the granite gneiss strikes north and south and dips about $15^{\circ}$ to the east. Granite gneiss near by strikes N. $10^{\circ} \mathrm{E}$., its dip being obscure.

The material at this quarry is of excellent quality for pottery purposes and the deposit is probably of considerable extent. Several small prospect pits in this vicinity were examined but showed only small amounts of commercial feldspar. Further prospecting may reveal other deposits of workable size.

The distance by road from this quarry to Cranberry Creek station, on the Fonda, Johnstown and Gloversville Railroad, is about $2 \frac{3}{4}$ miles. The haul from mine to railroad is downhill, but is over a rough road which descends 800 feet in a mile. A road over a better route could be constructed, or the spar could be mined in the summer and sledded out to the railroad during the winter. Up to the present time the work has consisted largely of prospecting.

\section{SARATOGA COUNTY.}

\section{CORINTH.}

A feldspar quarry in the town of Corinth, about $2 \frac{1}{2}$ miles southwest of Corinth station, on the Adirondack division of the Delaware and Hudson Railway, was opened about 1899, but up to the present time only sample shipments have been made. The property is owned by the American Feldspar and Mining Company, but for a short time the work was carried on under the name of the Corinth Feldspar Company. The workings consist of a lower small pit and an upper larger one, at an altitude 130 feet higher, on the same southeast hill slope. Only a few tons have been excavated from each. The rocks bordering the pegmatites are garnet schists in which the foliation is in some places obscure and in others well defined. Their strike varies from north-south to N. $30^{\circ} \mathrm{W}$., the average being about N. $15^{\circ} \mathrm{W}$. The average dip is about $20^{\circ}$ to the southwest. The trend of the pegmatite body seems in general to be about parallel to the strike of 
- the bordering schists, for its outcrops can be traced N. $25^{\circ}$ W. for nearly one-half mile beyond the present workings.

The deposit is a typical granite-pegmatite. The quartz varies from light to dark gray, and no pure large masses were observed. The feldspar is pearl-gray to bluish-gray orthoclase, which occurs in pure masses up to 6 inches across. Most of the material available commercially for pottery use is graphic granite. Brown biotite is the principal iron-bearing impurity. The best exposures of spar of pottery grade are at the lower pit, where masses of feldspar and graphic granite free from iron-bearing minerals are found, the largest 3 feet across. At the upper pit biotite is present in greater abundance, and it is doubtful if the spar is of pottery grade.

Some feldspar of pottery grade is undoubtedly present at this locality, but further prospecting should precede any attempts at development on a large scale.

EDINBURG.

Batchellervitle quarry.-A feldspar quarry operated by the Claspka Mining Company, of Trenton, N. J., is located about 2 miles north of Batchellerville, in the town of Edinburg, a few rods east of the Day-Batchellerville road. The mine was opened in 1906, and was visited by the writer in April, 1909.

The rock is a granite pegmatite, which has been worked from two open pits. The lower and larger pit, located near the base of a steep northwest hill slope, is about 15 feet in maximum depth. Quartz occurs in pure masses several feet across and also in graphic intergrowth with feldspar. The feldspar is light-gray microcline, finely intergrown with small amounts of albite. It occurs in pure masses, the largest 4 feet across, and the feldspars of some of some of the coarser phases of the graphic granite are 3 feet across. The finergrained parts of the pegmatite contain "books" of muscovite oriented in every direction. Some of the "books" are 16 inches in diameter and 8 inches thick at right angles to the plates. Many are tapering. Many of even the larger "books" show nearly perfect six-sided or diamond-shaped outlines. None of the mica seen was of commercial value except for grinding. It does not split well, and much of it is affected by ruling and contains numerous minute magnetite inclusions between the plates. Several tons of muscovite are piled at the quarry. Biotite is not abundant, but one flat crystal observed was 4 feet long and 3 feet wide. Beryl, of dark blue-green color, translucent to transparent, is moderately abundant, and one hexagonal prism seen was 8 inches in diameter and about 30 inches long. Another was about 2 feet long and tapered from a diameter of 7 inches at one end to 3 inches at the other. The pegmatite for 2 or 3 feet next to the contact of the pegmatite with the schist at this 
pit is an irregular or arborescent intergrowth of quartz and feldspar inclosing some large muscovite "books." The largest areas of pure feldspar and quartz lie immediately inside this contact zone.

The second and smaller pit is about 100 yards east of the first pit and higher up on the hill slope. It is about 20 feet wide and 7 or 8 feet in maximum depth. The pegmatite is in general similar to that at the lower pit, though showing certain differences. The quartz is white to light gray and pale rose. A pure mass exposed in the east wall of the pit is 3 to 4 feet wide and continuous for 20 feet. Feldspar similar to that at the lower pit occurs in pure masses 2 feet across and also in graphic and dendritic intergrowth with quartz. Muscovite and biotite are rare. Dark-red, semiopaque garnets up to $1 \frac{1}{2}$ inches in diameter occasionally occur, and one garnet aggregate or compound crystal was 8 inches across. On the dump piles were highly brecciated masses of feldspar whose fragments are cemented by a dark-colored matrix, which appears to be largely quartz and thin films of a nearly black substance containing iron and some organic matter and which is probably a mixture of substances deposited from solution in the spaces between the feldspar fragments.

At the lower pit the pegmatite is intrusive, with sharp contacts with a light-gray to dark-gray quartz-biotite-feldspar gneiss of variable character, locally containing pinkish orthoclase phenocrysts up to 1 inch in length. The contact in some places parallels the foliation and in other places cuts sharply across it. At the upper pit the gneiss exposed in the eastern wall shows no very well defined dip, but strikes about east and west, the pegmatite contact trending about N. $30^{\circ}$ W. sharply across the gneiss folia. Between the upper and lower pits are numerous exposures of gneiss striking about east and west and dipping about $15^{\circ} \mathrm{S}$.

The two pegmatite masses quarried at the upper and lower pits appear to be irregular in form. They may be connected beneath the surface, but do not appear to be so at the surface. At the upper working, gneiss striking N. $60^{\circ} \mathrm{E}$. and dipping $20^{\circ} \mathrm{SE}$. succeeds the pegmatite only 100 feet or so south of the pit, but the northward extension of the pegmatite is obscured by the soil covering.

The pegmatite is quarried in the usual way, with the aid of steam drills, and the product is hauled by teams 7 miles to the railroad at Northville. The length of haul over roads where some of the grades are steep is the greatest obstacle to the development of the property. The feldspar appears to be present in fair amounts and is of excellent - quality. 


\section{WESTCHESTER COUNTY.}

GENERAL STATEMENT.

The feldspar and quartz quarried in Westchester County occur as constituents of granite-pegmatite. The associated rocks are a mica schist (the Hudson schist) and scattered masses of crystalline limestone (the Stockbridge dolomite).

Both of these rocks are of sedimentary origin, though they are extensively altered by metamorphic action. They now lie in a series of closely compressed folds, whose general trend in the region here describea is northeast-southwest. The Hudson schist is of Ordovician age; the Stockbridge dolomite is in part Ordovician and in part Cambrian.

In the vicinity of the feldspar and quartz quarries and along much of the road between Bedford village and Mount Kisco the Hudson schist has been injected by granite, pegmatite, and basic igneous rocks, so as to show locally a gneissic texture. Here and there, as along the road from Bedford village to the Hobby quarry, in North Castle, small masses of normal granite occur. The pegmatites that are of commercial importance in this region are doubtless only one phase of the granitic intrusion and injection of the Hudson schist, and like the granites are probably of Silurian or later age.

The deposits which were visited by the writer in January, 1907, have been briefly described in a report of the New York State Museum, ${ }^{a}$ and from that description a portion of the material for this report is taken.

BEDFORD.

Kinkle quarry and mill.-The Kinkle quarry is situated on the east and northeast slopes of a small hill about three-fourths of a mile southeast of Bedford village. The excavations consist of four open pits, three closely adjacent ones on the upper part of the hill slope and one at a lower level. All the pits are elongate in a northeast-southwest direction, their trend probably coinciding with that of the pegmatite dikes. The lower pit.exposes the downward and northeastward continuation of the same pegmatite mass that is revealed in the southernmost of the upper pits.

The northernmost of the upper pits is about 50 feet wide, 100 feet long, and 35 feet in maximum depth. The two southern pits on this level are larger, being 100 to 150 feet wide, about 300 feet long, and about 50 feet in maximum depth. Most of the rock exposed in the central pit of the upper group is quartz, which is mainly white, but here and there assumes a very beautiful rose tint. Black tourmaline occurs in single crystals or radiating crystal aggregates in the quartz, 
and some of the fracture planes in the quartz are coated with thin layers of black tourmaline. These thin coatings, in few places over one-thirty-second of an inch in thickness, have plainly developed subsequent to the solidification and fracturing of the quartz and may be either secondary deposits from surface waters that percolated along the fractures or deposits from hot aqueous or gaseous solutions that penetrated the cracks in the pegmatite mass in the very latest stages of its solidification. Quartz with this black tourmaline coating is unfit for commercial use and is discarded. The quartz seems to be associated with the feldspar in a wholly irregular manner. It forms most of the northwestern and southwestern walls of this quarry, but in the southeastern wall is abundant only at the base, the upper parts of the wall being feldspathic. The feldspathic constituents of the pegmatite are best exposed in the other three pits, where they constitute a large proportion of the whole rock. The feldspar is of two principal varieties, one pink or flesh colored and the other white. When examined under the microscope, the pink variety shows the optical properties of microcline. It is finely intergrown with small amounts of albite. There is every gradation from pure potash feldspar through coarse-grained graphic granite into fine graphic granite. The pink feldspar, pure or in intergrowth with quartz, generally occurs in somewhat irregular but sharply bounded areas within the pegmatite mass. In the southernmost of the upper quarries these constitute about one-half of the mass. A few of the smaller pink feldspar areas have perfectly straight boundaries which parallel the cleavage directions within the crystal. One sharply outlined mass of pink feldspar 3 feet long by $1 \frac{1}{2}$ feet wide was bordered on all sides by white quartz. The larger masses are, as a rule, inclosed partly by pure quartz and partly by irregularly associated white quartz and white feldspar in varying proportions with a little pink feldspar, biotite, black tourmaline, beryl, or other mineral. The white feldspar, which is largely albite, constitutes the second important variety of feldspar characteristic of this quarry. The pegmatite containing it is in a few places graphic granite, but for the most part shows very irregular texture and varying proportions of feldspar and quartz from point to point.

The mica of these quarries is mainly muscovite, which is commonly associated not with the quartz but with the feldspathic portions of the deposit or may lie between feldspathe areas and areas of pure quartz. In places the mica "books" lie with their sides parallel to the quartz-feldspar contacts, but more generally they stand at right angles to these contacts. Few of them exceed 4 to 5 inches in diameter and almost all show "A" structure and much ruling. No plate mica was seen and the total amount of muscovite is hardly sufficient to make it worth while to save it for scrap mica. Being mainly 
confined to rather definite bands in the pegmatite most of it can be readily separated from the highly feldspathic portions. It is not injurious chemically either in pottery or in glass manufacture, but it is difficult to grind the thin elastic plates to the requisite fineness.

Biotite (black mica) occurs in long, thin, lath-shaped crystals, some of which are several feet long, though most of them are much smaller. Black tourmaline is associated mainly with the quartz, but is locally present in the feldspathic parts of the pegmatite. Magnetite and garnet occur in a few places, but no gem varieties of tourmaline or of beryl have been found. Columbite is present here and there in small crystals, as are some other rare minerals.

Three grades of feldspathic material are obtained from these quarries. No. 1 is selected from the purer portions of the pinkfeldspar masses and will probably run considerably less than 5 per cent of free quartz. All of it is shipped crude. The No. 2 feldspar produced at this quarry includes the coarser graphic intergrowths of pink feldspar (microcline) and quartz and also includes pegmatite material rich in the white soda feldspar, albite. This grade is therefore higher in free quartz and in soda than No. 1. Both the No. 1 and the No. 2 grades are used in the manufacture of pottery and must be entirely free from black mica, black tourmaline, garnet, and other iron-bearing minerals. The No. 2 spar is not shipped in the crude state, but is ground at the quarries. A No. 3 grade, made up mainly of the albite-quartz mixture with some of the finer grained pink graphic granite, is also ground at Bedford for use in glass manufacture. It is somewhat higher in quartz and soda than grade No. 2, and muscovite, biotite, and black tourmaline are not so carefully eliminated as in grades No. 1 and No. 2, these constituents not being so injurious in glass as in pottery manufacture. Microscopic examination of the No. 3 spar shows the presence of free quartz, microcline (potash feldspar), and albite (soda feldspar).

The quartz from this quarry is shipped in the crude state to the Bridgeport Wood Finishing Company at New Milford, Conn., where it is ground and used in the manufacture of a wood filler, of silica paint, etc.

The grinding mill of Kinkle's Sons is located at the quarries and is similar in equipment to most feldspar mills elsewhere, except that the spar as it comes from the chasers goes to a vibration separator, only the tailings being sent to the ball mills. For pottery spar this separator is provided with a 140-mesh screen, but in the preparation of spar for glass manufacture only a 60 -mesh screen is required.

The ground spar is usually shipped in bags. All the product is hauled by team 5 miles to Bedford station, on the New York Central Railroad. The No. 1 and No. 2 grades, for pottery use, are shipped 
mainly to Trenton, N. J., and East Liverpool, Ohio, though small amounts have been shipped as far as Portland, Oreg.

\section{NORTH CASTLE.}

Hobby quarries.-A small quarry owned by Albert Hobby, of Bedford, N. Y., opened by Otto Büresch, but now operated by P. H. Kinkle's Sons, is located in the town of North Castle, near the west side of Mianus River, about $1 \frac{1}{2}$ miles southeast of the Kinkle quarry. The quarry is situated on a steep eastern hill slope and is about 100 feet wide, 150 feet long, and 40 feet in maximum depth. No exposures of the surrounding rocks were observed near the quarry. The pegmatite shows masses of pure feldspar 8 to 10 feet across, associated with masses of pure quartz, some of which are 15 feet across. The quartz is in part white and in part a beautiful rose tint. There is almost no intergrowth of quartz and feldspar. The feldspar is buff and is shown by microscopic examination to be microcline-potash feldspar, probably containing a little soda. Small and very thin plates of muscovite occur along some of the cleavage planes in the feldspar, but they are not abundant enough to affect the quality of the spar materially. Muscovite in larger plates is mainly segregated in somewhat irregular bands in associa'tion with black tourmaline in prismatic crystals that reach $1 \frac{1}{2}$ inches in diameter.

This quarry differs from the Kinkle quarry in the fact that the feldspar is practically all buff microcline, and in the more complete separation of quartz and feldspar, graphic granite being apparently wholly absent. The present exposures cover only a small area, and it is impossible to determine the extent or uniformity of the deposit. Mianus River is capable of furnishing ample water power for operating a grinding mill, and the materials could be carried by gravity down the hill slope to the mill. The material is hauled by teams 8 miles to Bedford station. Little material has yet been marketed. It is unfortunate that this property is so far from transportation lines.

A small quarry owned by Mr. Hobby, situated about one-half mile east of the Kinkle quarry, is not now being operated and was not visited by the writer.

\section{PENNSYLVATIA.}

\section{GENERAL STATEMENT.}

Nearly all the feldspar quarries of Pennsylvania are in Chester and Delaware counties, in the southeastern part of the State. A single quarry, long abandoned, is in Montgomery County. The location of the active and inactive quarries and of the feldspar mills is shown in Plate VIII. Most of the pegmatite deposits are of the 
usual type of granite pegmatite, but those in the extreme southwest part of Chester County, near the Maryland State line, belong to an entirely different type, which may be designated soda pegmatite, its principal mineral being the soda feldspar, albite. This variety contains no quartz and its principal iron-bearing mineral is hornblende. The masses of granite-pegmatite that have been quarried are, as a rule, associated, as shown in Plate VIII, with areas of Wissahickon mica gneiss, a foliated quartz-feldspar-mica rock of pre-Cambrian age. Most of the pegmatite masses appear to be elongate in a general way parallel to the trend of this gneiss - that is, from northeast to southwest.

The soda pegmatites of southwestern Chester County and adjacent portions of Maryland are for the most part intrusive in serpentine, representing altered peridotites and pyroxenites that are early Cambrian or older. The age of the pegmatite dikes themselves is not definitely known. The granite-pegmatites intrude rocks that are supposed to be of Ordovician age. Some of them are therefore considered to be at least as young as Ordovician, though others may be older.

A part of the feldspar quarried in the State is ground at mills near Brandywine Summit, at Toughkenamon, and near Sylmar, Md. Most of the remainder is shipped crude to Trenton, N. J., or Wilmington, Del.

The quarries that were active in 1898 have been briefly described by T. C. Hopkins. ${ }^{a}$ The observations of the writer were made in 1907.

\section{CHESTER COUNTY.}

Most of the quarries of Chester County that produce potash feldspar are in the vicinity of Avondale; those that produce soda feldspar are in the extreme southwestern part of the county, near Sylmar, Md.

\section{LONDON GROVE.}

Pennsylvania Marble and Granite Company's quarry.-The feldspar quarry of this company is about one-fourth of a mile southeast of the large granite quarry of the same company at Baker station. At the time of the writer's visit in May, 1907, the deposit had been worked for only a short time. The quarry pit was about 50 by 30 feet and 25 feet deep. The main pegmatite dike appears to be about 25 feet wide. It strikes $\mathrm{N} .75^{\circ} \mathrm{E}$. and dips about $50^{\circ}$ to the southeast. The rock is pegmatite of the fine-grained gneissic type observed at the Eureka Flint and Spar Company's quarry, $1 \frac{1}{2}$ miles north-northwest of Avondale. The crystals of pure feldspar tend to be lens shaped

$a$ Hopkins, T. C., Clays and clay industries of Pennsylvania, part 2: Appendix to Ann. Rept. Pennsylvạnia State College for 1898-99. 


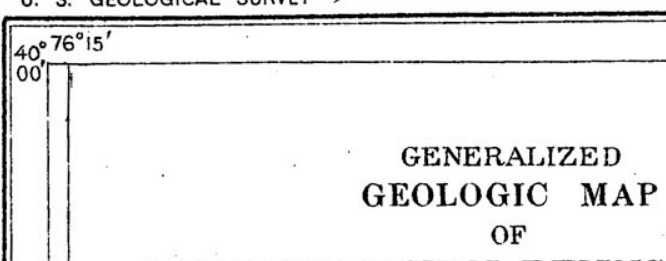

SOUTHEASTERN PENNSYLVANIA AND ADJACENT PARTS

DELAWARE AND MARYLAND Showing location of feldspar quarries and mills

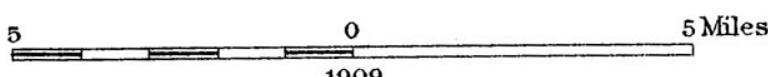

$\stackrel{0}{1909}$ 5 Miles
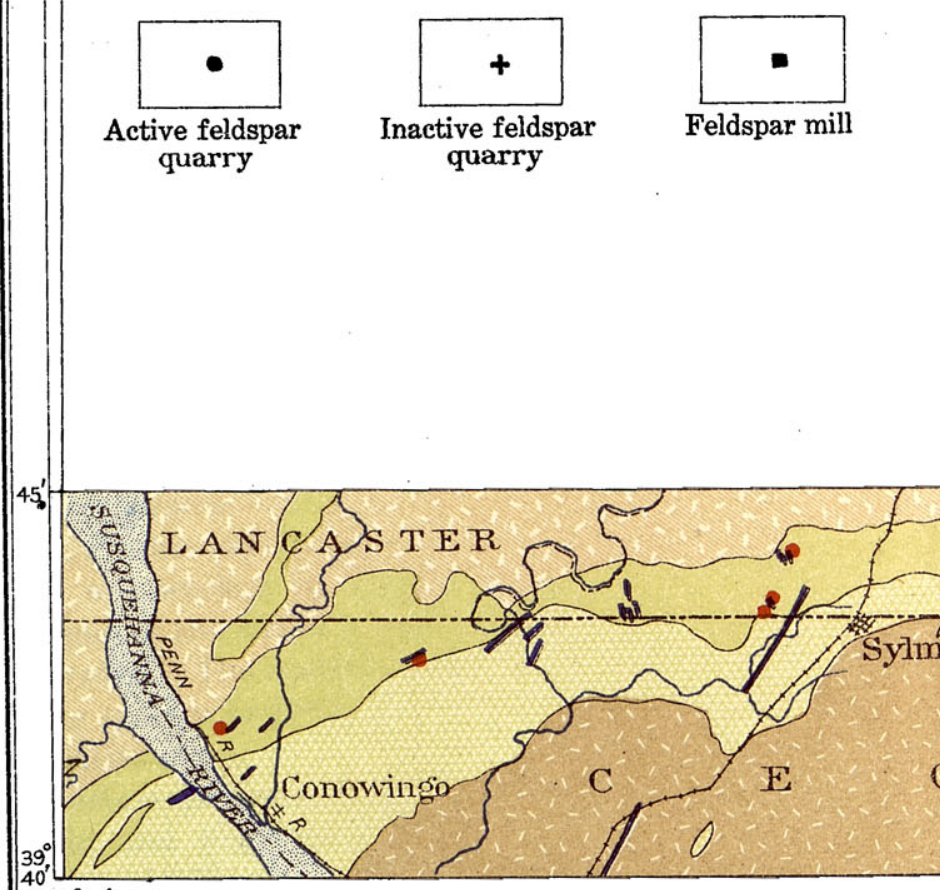
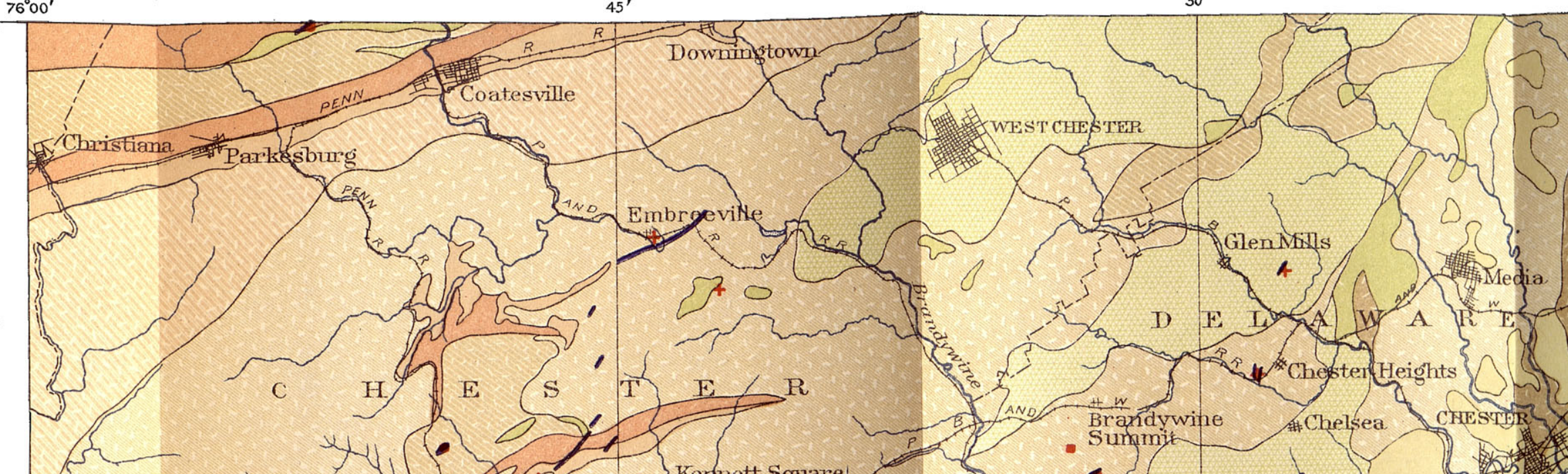

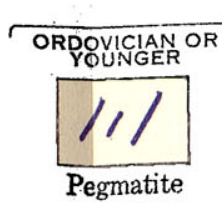

i. I. त 2 .
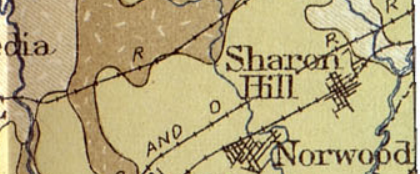

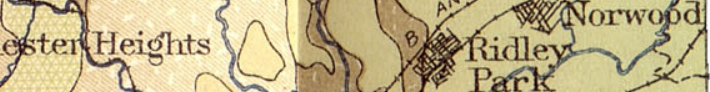

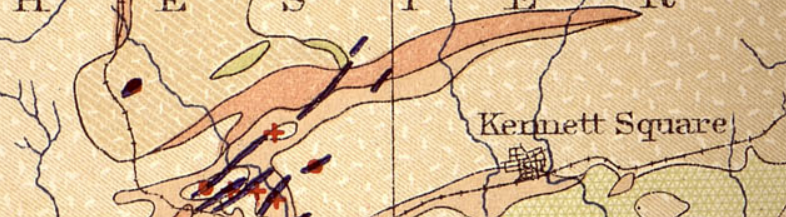

(
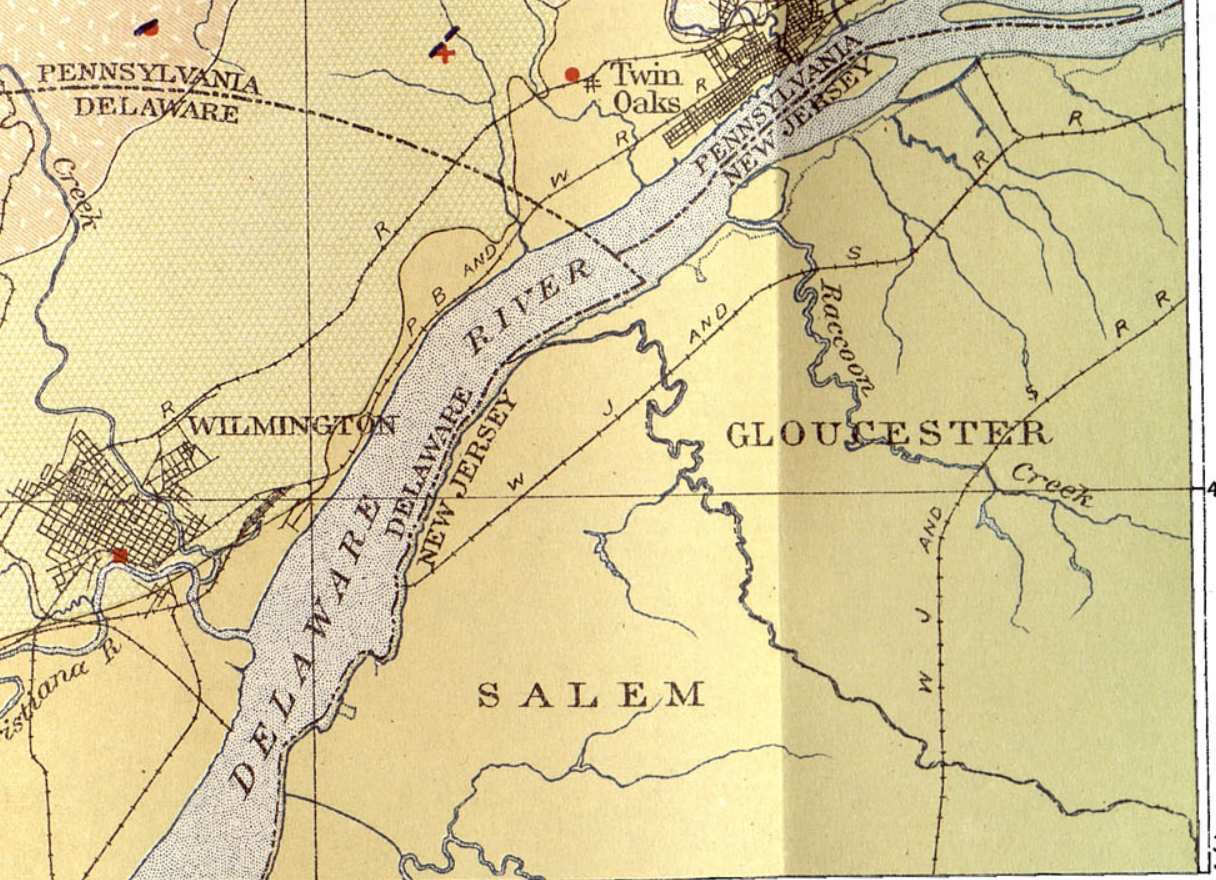

GNEOUS ROCKS
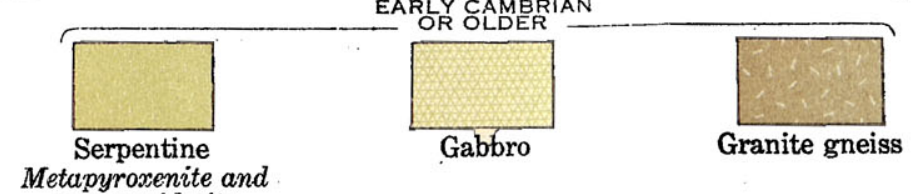

and few of them are more than 3 or 4 inches across. Muscovite plates are as a rule not more than $1 \frac{1}{2}$ inches across. Biotite is abundant along certain bands and renders these commercially worthless. There are occasional small garnets. No graphic granite was seen. Most of the quartz is in irregular intergrowth with the feldspar, and no pure masses over a foot across were observed. The material which was being quarried at the time of the writer's visit was mostly soft and could be worked with a pick and shovel. The quarry was equipped with a derrick and steam hoist, sixteen men being employed. It was not operated in 1908 .

Thompson quarry.-A feldspar quarry $1 \frac{1}{2}$ miles northwest of Avondale and three-fourths of a mile northeast of Baker station was formerly operated by J. N. Thompson for the Eureka Mining and Operating Company of Trenton, N. J. It consists of a series of narrow pits distributed along a pegmatite dike trending $\mathrm{N} .55^{\circ} \mathrm{E}$. and dipping, at the northernmost pit, about $40^{\circ}$ to the southeast. Most of the pits are now filled with water, but the workings at one pit are said to have reached a depth of 60 feet.

The rock is a granite-pegmatite of fine grain and more or less gneissic texture, due mainly to the concentration along certain bands in the rock of small muscovite plates, most of them under one-half inch across. No crystals of pure feldspar over 3 inches across were seen. The feldspar crystals are mostly lens shaped, with their long direction parallel to the gneissic structure. A few crystals graphically intergrown with quartz are 5 inches across. There are some small garnets, most of them under one-eighth inch in diameter. Biotite appears to be entirely absent.

As far as can be determined from a casual inspection the supply of feldspar at this quarry appears to be about exhausted.

Baker quarry.-A small quarry just east of that of the Pennsylvania Marble and Granite Company, on the other side of the wagon road, was worked by Thomas Baker and was opened in 1907. At the time of the writer's visit, in May, 1907, only a few tons had been excavated. The material is in every way similar to that at the neighboring quarry and the rock seems to be a continuation of the same pegmatite mass.

Chatham quarry.-A quarry operated by the Brandywine Summit Kaolin and Feldspar Company is located three-fourths of a mile northeast of Chatham village. The rock is a typical granite-pegmatite. The quartz is white and occurs in large, pure masses, and also irregularly intergrown with feldspar. Graphic granite was not observed. The feldspar is pinkish-gray microcline, the largest crystals being 1 foot across, though most of them are smaller. The greater part of the material quarried is an irregular intergrowth of quartz and feld16779-Bull. $420-10-5$ 
spar through which minute mica plates are scattered. Biotite is the principal iron-bearing impurity.

The pegmatite here worked is a more or less flat-lying mass, at least 25 feet thick, the base being nowhere exposed. It has been worked from an open pit about 100 feet long by 80 feet wide by 40 feet deep, and in the wall of this pit the pegmatite is seen to be overlain by mica schist. From the southern end of the open pit a tunnel 12 feet high, 20 to 25 feet wide, and 40 feet long was being driven at the time of the writer's visit in May, 1907. The pegmatite in part follows the foliation planes of the schists, but also at many places cuts sharply across them. It is estimated that about one-half of the material quarried is ore and one-half waste. The quarry is equipped with steam pump, steam hoist, and derrick, and about fifteen men are usually employed. Future working must be mainly by tunneling, and there is some question whether this could be profitably conducted for any great distance with material of this kind. The spar is hauled three-fourths of a mile to Chatham and shipped by rail to the mill of this company near Brandywine Summit, Delaware County.

\section{NEW GARDEN.}

Toughkenamon quarry. - This quarry, which is operated for the Pennsylvania Feldspar Company of Philadelphia, is on land owned by Moses B. Carpenter, $1 \frac{1}{2}$ miles northwest of Toughkenamon. The largest pit at this locality had long been abandoned at the time of the writer's visit in May, 1907, when only small openings were being worked, apparently located in several distinct pegmatite dikes. The pegmatite now worked is not so coarse as that at most feldspar quarries, no crystals of pure feldspar being observed which were over 2 to 3 inches across. The pegmatite of the old abandoned pit is said to have been much coarser. Quartz does not occur in commercial quantities. The feldspar is buff to pink microcline, finely intergrown with small amounts of albite. The muscovite plates associated with the feldspar are as a rule not more than $1 \frac{1}{2}$ inches across. As at a number of other quarries in this region the pegmatite shows an indistinct gneissic texture.

The feldspar is hauled to the mill of the Pennsylvania Feldspar Company at Toughkenamon.

Toughkenamon feldspar mill.-This mill, which is operated by the Pennsylvania Feldspar Company, stands at the side of the railroad in Toughkenamon village. The equipment consists of a Blake crusher, chaser mill, and four small tube mills. The capacity is stated to be 8 to 9 tons in ten hours. 
NEWLIN.

Embreeville and Unionville abandoned quarries.-There is an abandoned quarry near Embreeville, on the Wilmington division of the Philadelphia and Reading Railway. This quarry was not visited by the writer, but its appearance in 1898 is described as follows by Hopkins: ${ }^{a}$

The spar quarry at Embreeville is about 100 yards north of the Embreeville station. The vein, which is about 10 feet thick, crosses the railroad and has been quarried on both sides of the railroad track. The vein appears to correspond in dip and strike to the garnetiferous mica schists in which it occurs. * * * The spar is nearly snow white, slightly stained by dendrite markings in places. The analysis indicates a soda orthoclase with a slight admixture of a lime-bearing feldspar and considerable free quartz. $* * *$ The continuation of this vein southwest from the quarry is distinctly shown by the numerous outcrops at different points along the line of strike, and the outcrop would indicate that other quarries might be opened with profit.

Several small feldspar quarries northeast of Unionville, now abandoned, but worked at the time of Hopkins's visit in 1898, are described by him as follows:

Feldspar was quarried from four openings during the present season, and there are not less than half a dozen other openings from which spar has been removed within the last few years. The quarries are comparatively shallow and indicate an occurrence of the feldspar in pockets rather than veins, although they are probably enlargements of veins, but the country rock has so disintegrated that the spar lies in the loose, disintegrated material, and the vein walls are not clearly defined. The rock is a mica schist bordering on serpentine, and some of the quarries are apparently within the serpentine area. Muscovite and biotite are quite abundant in places and there is considerable diffused quartz, but no large masses were observed. A band of green serpentine occurs in one of the quarries, and tourmaline crystals are reported.

\section{WEST CALN.}

Meredith quarry.-A quarry $1 \frac{1}{4}$ miles north-northeast of Sadsburyville and $2 \frac{1}{2}$ miles north of Pomeroy is operated by B. F. Meredith, of Pomeroy. The workings here are rather irregular in form. The largest pit, the one now being worked, is 150 feet long from north to south and averages about 50 feet across. The pegmatite mass is so irregular in form that its general trend can not be determined. On the east side of the largest pit, however, where it is excavated from a short tunnel, it is overlain by schist. Quartz seldom occurs in large, pure masses. The feldspar is cream-colored to pink microcline, not much of it in pure masses, but most of it finely intergrown in a graphic manner with quartz, so that the greater part of the commercial product is fine graphic granite. Greenish mica in small plates is the only other abundant constituent. The pegmatite is very free from iron-bearing minerals. The quarrying is done by steam drilling and blasting, and the product is hauled by teams $2 \frac{1}{2}$ miles to the railroad at Pomeroy. 
WEST NOTTINGHAM.

Three quarries, which produce only soda feldspar, are in West Nottingham, Md., near the Pennsylvania-Maryland State line. The rock obtained at these quarries is not a granite-pegmatite, but a soda pegmatite, the principal minerals being soda feldspar (albite) and hornblende.

Sparvetta quarry.-The westernmost of these quarries is operated by the Sparvetta Mining Company, and is located about $1 \frac{1}{2}$ miles west of Sylmar station, Maryland. At the time of the writer's visit, in May, 1907, the quarry was an open pit 400 or 500 feet long, 50 to 150 feet wide, and 80 feet in maximum depth. The greatest length is in a direction N. $55^{\circ} \mathrm{W}$., and this appears to represent the general trend of the feldspar mass. The working taps two feldspar masses of nearly parallel trend, but of different dip, the dip of one being approximately vertical, while that of the other is so inclined that it joins the first near the bottom of the quarry to form a single vein. The southwestern of these two feldspar masses is only 5 to 10 feet wide near the surface, but broadens downward. There is no evidence that the pegmatite dies out for some little distance in either direction along its trend, and presumably it also continues downward to a considerable depth. The wall rock is serpentine, dark green to nearly black in color. At the contact between the two, within a zone that is for the most part about a foot wide, talc and some fibrous serpentine are commonly developed, the fibers of the serpentine being oriented perpendicular to the contact and being mostly 1 inch to $1 \frac{1}{2}$ inches in length. Neither of these minerals is utilized commercially.

The character of the feldspar from this and the other two quarries in this vicinity is described later.

The quarrying is done by steam drilling and blasting, and the material is hoisted by derricks and transferred to a mill at the side of the quarry. Here it is heated in a continuous feed kiln and when hot is sprayed with cold water. This operation shatters the spar and makes grinding much easier. It is then crushed in three chaser mills of the usual type and ground in tube mills. Two of the latter are of the small type found in most feldspar mills, grinding 2 to 3 tons at a charge. The other is a large mill having a capacity of 5 to 6 tons, which, as originally installed, was a continuous feed mill, but difficulty in regulating the quality of the product led to its alteration to the intermittent type. The capacity of the mill is stated to be about 25 tons in twelve hours.

Keystone quarry.-A quarry operated by the Keystone Feldspar Company, of Philadelphia, is located a few hundred yards southeast of the Sparvetta quarry, probably on a continuation of the same 
feldspar mass. The pit is about 350 feet long, 150 feet wide, and 80 feet in maximum depth, its greatest length being from northwest to southeast. The spar here constitutes a single vein, and is similar to that at the Sparvetta quarry. The wall rock is serpentine. The amount of material here seems to be large, and there is no indication of its dying out for some distance downward or along its trend.

The quarry is equipped with two derricks, a steam hoisting engine, a steam pump, and steam drills. It employs a crew of fifteen to twenty men. The material is hauled $1 \frac{1}{2}$ miles to Sylmar station and is all sold in the crude state.

Brandywine quarry.-A quarry of the Brandywine Summit Kaolin and Feldspar Company, one-half mile north of the Sparvetta quarry, is 200 feet long, 70 to 80 feet wide, and 90 to 100 feet deep, the greatest length being in a direction N. $10^{\circ} \mathrm{W}$. The feldspar constitutes a single dike, which is about 12 feet wide at the south end of the pit, but broadens toward the north end. The wall rock is serpentine and the contact is marked by a zone, about 1 foot thick, of bluegreen talc, now much decomposed.

The equipment consists of a derrick, steam hoisting engine, steam pump, and steam drills. From fifteen to eighteen men are employed. It is probable that the vein extends both to the north and to the south beyond the present exposures, and the excavations can also with safety be carried to greater depths. A part of the output is sold to the Sparvetta Mining Company and hauled to their mill for grinding. The remainder is hauled $1 \frac{1}{2}$ miles to Sylmar station and shipped to the mill of the Brandywine Summit Kaolin and Feldspar Company, near Brandywine Summit.

Character.-The feldspar at the three quarries described is entirely similar in character, as are also the associated minerals. The feldspar is of the soda variety (albite), occurring generally in crystals that are from 1 inch to 2 inches across, though some are as much as a foot across. The crude feldspar varies from white through cream to gray; the ground product is pure white.

So far as observed, quartz is entirely absent in pegmatites of this variety. The principal iron-bearing mineral is hornblende, which appears dark green under the microscope but nearly black as seen in the quarry. It is in aggregates of needle-like crystals, many of them radially arranged, which occupy spaces between the feldspar grains. Muscovite occurs in certain portions of the pegmatite, intergrown with feldspar so as to form more or less rounded aggregates 5 to 6 inches across. Most of the single plates are not more than $1 \frac{1}{2}$ inches across. Small garnets are locally associated with the feldspar. Along some of the fracture planes there are thin films of ocher, but these do not materially damage the spar. Some asbestos of the ser- 
pentine variety and some talc, as already stated, is found along contacts between the feldspar masses and the wall rock, but they are not present in commercial quantities.

\section{DELAWARE COUNTY.}

Feldspar is now quarried only at one locality in Delaware Countynamely, at Elam, near Brandywine Summit-but in the past was quarried near Chester Heights, near Glen Mills, and near Chelsea.

\section{CONCORD.}

Brandywine Summit Feldspar Company.-The quarry of this company is at Elam, $1 \frac{1}{2}$ miles south of Brandywine Summit station, within the area of the West Chester topographic map of the United States Geological Survey. The excavations here cover an area of about 4 acres, and consist of three partly connected open pits. The eastern and largest pit, now abandoned, is about 300 feet from north to south and 250 feet from east to west. It is now filled with water to a level within about 60 feet of the surface, but is said to have been nearly 200 feet deep. A second pit, west of the first and connecting with it, is about 125 feet from north to south and 150 feet from east to west. This pit is also abandoned. The pit now being worked lies just west of this. From the easternmost pit, now partly filled with water, much material was excavated from tunnels, which were driven for over 300 feet. The two western pits are much shallower.

The feldspar, which is of the potash varieties, orthoclase and microcline, is cream to flesh colored, and occurs in pure crystals ranging up to slightly more than a foot in diameter. Unlike most quarries yielding potash feldspar, no graphic granite was observed, most of the quartz being irregularly intergrown with the feldspar or other pegmatite minerals. The quartz is gray in color and granular in appearance because of minute fracturings, and in the present workings seldom occurs in pure masses of any considerable size. It is not utilized commercially. According to Hopkins, ${ }^{a}$ however, large masses of pure quartz were formerly exposed near the bottom of the eastern pit and future excavations may disclose other quartz masses.

Muscovite occurs both in small crystals and in large plates up to 18 inches across, but none of it is of commercial grade. Delicate skeleton crystals of magnetite are common between the mica plates. Biotite is abundant in certain portions of the pegmatite in thin, narrow crystals, some of them several feet long; and wine-red garnets occasionally occur, usually associated with the mica. The mica and garnet-bearing portions of the pegmatite can be readily separated in mining from the areas of purer feldspar.

\footnotetext{
$a$ Hopkins, T. C., Clay and clay industries of Pennsylvania, part 2: Appendix to Ann. Rept. Pennsyivania State College for 1898-99.
} 
The deposit seems in general to be rather flat Iying, as is indicated by the occurrence on the north wall of the eastern pit of about 40 feet of mica schist, beneath which the pegmatite dips apparently at an angle of about $25^{\circ}$. The eastern pit is said to have been excavated to a depth of nearly 200 feet. In the western pit, which is now being worked, the pegmatite mass is at least 30 feet thick, its base not having yet been reached.

The soft, weathered material near the surface can be excavated with pick and shovel, but the material at greater depth must be removed by steam drilling and blasting and hoisted by derrick. The product is loaded into wagons and hauled about $1 \frac{1}{2}$ miles to the mill. Most of the spar is used for pottery; but the cleaner pieces, which are selected with extreme care, are sold by the barrel for dental purposes. Up to the present time the quarry has probably yielded over 150,000 short tons of crude feldspar. The appearance of this quarry in 1898 is described on pages $14-15$ of Hopkins's report. ${ }^{a}$

The mill is located on a private spur of the Philadelphia, Baltimore and Washington Railway, about a mile southwest of Brandywine Summit station. The process of grinding at this mill is similar to that used at most other feldspar mills, the material being first crushed in chasers and then ground in tube mills, the principal differences from other mills being in the use of a mechanical carrier for removing the crushed feldspar from the chasers and transferring it to bins over the tube mills, and in the use of large tube mills, instead of the small tube mills usually employed. It is said that these effect a considerable saving in power. A suction fan is also employed to collect fine feldspar dust, about one bag of this being obtained in the course of a day. This dust can be marketed for certain purposes, and the device serves to keep the mill much freer from dust than it otherwise would be and to make the work less disagreeable for the men.

Some soda feldspar from a quarry belonging to this company in Nottingham, Chester County, is also ground at this mill. This soda feldspar is burned in a kiln and cooled by a stream of cold water before crushing. This process fractures the spar and renders the crushing and grinding process less difficult. The potash spar is ground just as it comes from the quarry.

Chester Heights abandoned quarries.-Feldspar for pottery and dental purposes was formerly quarried at this locality by the Chester Heights Feldspar Company. The quarries here have produced no feldspar for many years, and the locality was not visited by the writer. Its appearance in 1898 is described by Hopkins ${ }^{b}$ as follows:

At Chester Heights the spar has been quarried from six different openings and occurs as a vein deposit in micaceous rocks, the veins having a general northeastsouthwest trend, varying in width from 8 to 20 feet. The quarries are 40 to 50 feet 
deep, except one, which is an underground working and has been started on the vein near the base of the hill by running a horizontal drift into the hill following the vein. Some of the spar consists of graphic granite, some is nearly free from quartz, and in one opening quartz occurs in large quantities. The spar is all shipped to the mill at Brandywine Summit.

\section{MIDDLETOWN.}

Sharpless abandoned quarry.-A quarry about $1 \frac{1}{4}$ miles east of Glen Mills was operated many years ago, but was never a large producer. It had been idle a number of years at the time of Hopkins's visit in 1898. According to Hopkins, ${ }^{a}$ "The spar contains large segregations of quartz and large muscovite crystals, some of which "are 8 to 10 inches across."

Chelsea abandoned quarry.-A quarry which was formerly productive, but has now been idle for many years, is located about midway between Chelsea and Boothwyn station. It has not been visited by the writer, but in 1898, according to Hopkins, ${ }^{a}$ the quarry opening was about 150 feet long and 40 feet deep in a vein about 30 feet wide.

\section{MARYLAND.}

The active feldspar quarries of Maryland are in Cecil County and near the Patapsco River valley in Howard and Baltimore counties. The worked deposits of Cecil County are of the soda pegmatite type, like those just across the line in Pennsylvania, and show a similar association with serpentine and talc. Their location is shown in Plate VIII. Most of the quarries of Howard and Baltimore counties are typical granite-pegmatites, occurring near the border of considerable areas of granite, to which they are probably related in origin. The pegmatite at the Frost quarry; near Woodstock, is more or less intermediate in composition between the typical granite-pegmatites and the soda pegmatites, as is more fully shown below.

The bulk of the feldspar quarried in Maryland is ground either at Trenton, N. J., or at Wilmington, Del. A small part of the output is ground at the mill of the Eastern Flint and Spar Company, in Baltimore. In 1908 there were nine producers in the State.

\section{BALTIMORE COUNTY.}

Eureka quarry.-A quarry 2 miles north of the village of Granite was opened in September, 1907, and is operated by the Eureka Mining and Operating Company. When visited by the writer, in April, 1908, it consisted of a single pit 40 by 40 feet and 25 feet deep.

The rock is a typical granite-pegmatite. No large masses of pure quartz were observed. The feldspar is flesh-colored microcline, much 
of it graphically intergrown with quartz. White albite also occurs in irregular intergrowth with quartz. None of these varieties are found in pure crystals more than 3 or 4 inches in diameter. Biotite is the only other abundant mineral and occurs in small scattered lath-shaped crystals 3 to 4 inches long.

The trend and extent of the pegmatite mass could not be determined. At the west end of the pit the pegmatite is in contact with decayed mica schists that trend about $30^{\circ} \mathrm{W}$. If we assume a parallel trend for the pegmatite body, it would perhaps connect with the pegmatite formerly worked by the Golding Sons Company, a few hundred yards to the southeast.

Since the writer's visit this quarry has been a heavy producer, and the workings are presumably considerably extended. Six men were employed, and the material was hauled by teams to Granite for shipment by rail to the mill of the company at Trenton, N. J.

Parlet and Cavey quarry.-A quarry operated by Parlet and Cavey is on the C. H. Johnson place, a few miles east of Woodstock station, on the northeast slope of the Patapsco River valley. The deposit consists of several rather flat-lying masses of granite-pegmatite separated by irregular bands of mica schist. The maximum depth of excavation is only about 30 feet. Very little pure feldspar is encountered, most of the product being an irregular or graphic intergrowth of feldspar and quartz. The feldspar is prevailingly buff and is microcline. Biotite is the most abundant accessory mineral and renders certain portions of the deposit worthless. Some of the finergrained parts are virtually a coarse biotite gneiss, and even in the coarser portions a faint parallel structure is traceable. Much of the material is so disintegrated that it can be excavated without blasting. The spar is hauled to Woodstock station for shipment.

Guilford and Waltersville Granite Company's quarry.-This company operates a feldspar quarry about 1 mile due east of Woodstock, on the railroad spur to Granite. The quarry consists of a single pit about 100 feet long, 60 feet wide, and 35 feet in maximum depth. The rock is a granite-pegmatite, showing a number of large areas of pure light-gray quartz, one of which was 11 by 10 feet on its exposed surface. The quartz is saved in the mining. Several masses of pure feldspar are 3 to 5 feet across. Most of it is flesh-colored microcline, which is here and there intergrown with a little albite. Smaller crystals of feldspar are white, decompose more readily, and are shown on testing to be albite. Biotite, which is next in abundance to the quartz and feldspar, occurs in lath-shaped crystals, some of them 5 inches wide and 2 to 3 feet in length. Garnet appears to be entirely absent. 
The pegmatite mass seems to be an irregular intrusion that follows in general the trend of the bordering biotite schist, which at this locality strikes nearly east-west and dips $30^{\circ}$ to $70^{\circ} \mathrm{N}$.

The quarry was opened in 1906 and is equipped with air drills. About ten men are employed, and the feldspar after sorting is transferred by a chute directly to cars on the railroad siding.

French quarry.-A small quarry. operated by J. T. French is located half a mile north of Hollofield station. It is an irregular pit, 125 by 30 feet and 30 feet in maximum depth. It was visited by the writer in May, 1907. The pegmatite is similar in character to that at the Fagan quarry, described below, and the form of the mass seems to be quite irregular. The soil covering is heavy and interferes considerably with the economical working of the deposit. At the time of the writer's visit the quarry was not being operated, and was not equipped with any machinery. The material is of moderately good quality, but its extent could not be accurately determined.

Fagan quarry.-A quarry operated by E. E. Fagan is located half a mile south of Hollofield station, near the top of the eastern slope of the river valley. There are several pits at this locality, the one that was worked at the time of the writer's visit being about 100 feet long, 25 to 30 feet wide, and 20 feet in maximum depth. The largest diameter of the pit represents the trend of the pegmatite dike, which is the largest yet found in this immediate vicinity. Its trend is about N. $45^{\circ}$ E., nearly parallel to that of the bordering mica schists. The schists are greatly contorted and together with the pegmatite are much decayed, even to the maximum depth of exposure, which is about 20 feet. The quartz is light gray and occurs in masses large enough to be worth saving in the feldspar mining. The feldspar is principally pink microcline, much of it graphically intergrown with quartz. No pure masses over 3 feet across were observed, but a few up to 6 feet are reported to have been found in the past. In one place the pegmatite was cut by two small dikes of gray quartz, each about 4 inches across, which are slightly feldspathic here and there, especially at their borders, where they show crystallographic continuity with the bordering pegmatite. Besides the pink microcline there are small amounts of white albite, most of it irregularly intergrown with quartz. The next most abundant mineral is muscovite, which occurs principally in graphic intergrowth with quartz and feldspar and also in more or less rounded aggregates of small plates oriented in every direction. Biotite is also occasionally found, as is black tourmaline, in crystals up to $1 \frac{1}{2}$ inches in diameter.

The second pit, not now worked, is 60 by 30 feet and 20 feet in depth. The pegmatite mass appears to be rather flat-lying. Much 
of the material can be excavated with the aid only of the pick and shovel and is screened to free it from soil and the more decomposed portions. It is hauled for shipment to Hollofield station.

HOWARD COUNTY.

Brown quarries.-A number of small quarries about three-fourths mile southeast of Woodstock station, on the farm of W. H. Brown, are worked by Parlet and Cavey. At the time of the writer's visit, in May, 1907, the workings were not extensive. The rock in all of the pits is more or less similar. It is a granite-pegmatite showing only small masses of pure quartz or feldspar, most of the output being a graphic or irregular intergrowth of these minerals. The feldspar is buff microcline. Many of the other pegmatite dikes of this locality are similar to this one. The material here, as in most of the other quarries of this region, is weathered for some distance from the surface and much of it can be excavated without blasting. It is hauled for shipment to Woodstock station.

A number of other small quarries not visited by the writer have been operated in the vicinity of Woodstock.

Frost quarry.-The largest quarry in this region is about half a mile south of Davis station and $1 \frac{1}{2}$ miles southeast of Woodstock, on the Frost farm, and is operated by the Golding Sons Company of Trenton, N. J.

This quarry is located in a pegmatite deposit of a character somewhat different from those described above. In April, 1908, this quarry was about 450 feet long by 100 wide by 65 in maximum depth, its greatest dimension trending about N. $60^{\circ} \mathrm{E}$. The feldspar is of two varieties: (1) Orthoclase and microcline varying from light gray to pale flesh colored, and (2) white to gray soda feldspar (albite). The potash feldspar is in places in pure crystals, some of them as much as 4 feet across, and also in graphic or dendritic intergrowths with gray quartz. The soda feldspar is equal to if not greater than the potash feldspar in quantity, but is in smaller crystals, not many of them more than a few inches in diameter. The largest observed was about 1 foot across. Black mica (biotite) is entirely absent and white mica (muscovite) occurs only rarely and in plates less than an inch across. Quartz doesnot occur in large masses, but is mostly intergrown with feldspar. The principal iron-bearing impurity is green hornblende, which is found in prismatic crystals up to 1 foot in length. Pyrrhotite also occurs in small quantities, usually with the hornblende. It will be noted that in mineral character this pegmatite is intermediate between the two types previously mentioned. The abundance of albite feldspar, the presence of hornblende, and the scarcity of mica relate it to the deposits of soda spar worked near Sylmar, in southwestern Chester County, $\mathrm{Pa}$., while the presence of 
quartz and of potash feldspar, some of it graphically intergrown, relate it to the typical granite-pegmatites.

In this quarry a steam drill is used and a derrick is operated by a hoisting engine. The material is hauled about a quarter of a mile to the railroad and is shipped to Trenton, N. J., and Wilmington, Del.

\section{CECIL COUNTY.}

Only two firms are now operating in Cecil County, and these are quarrying talc as well as feldspar. The deposits belong to the soda type and are similar to those across the state line in Chester County, Pa., near Sylmar, Md.

Bald Friar quarry.-A number of small quarries were opened in 1906 at Bald Friar, $1 \frac{1}{2}$ miles north of Conowingo, by the Deland Mining and Milling Company, of Havre de Grace.

Talc is the principal output at this locality, and is ground at a mill near the quarries. "Feldspar is a secondary product, and is all . shipped in the crude state. The quarries in May, 1907, consisted of a number of small pits along the upper part of the bluffs bordering the Susquehanna. The feldspar when fresh is snowy white and is of the soda variety (albite). Near the surface, where the material is weathered to some extent, there is a slight iron discoloration along the fractures, but this is not sufficient to damage materially the quality of the product. The veins range in width up to 15 feet and show numerous pinchings and swellings. They occur as intrusions in an area of rocks which are mapped on the Cecil County sheet of the Maryland Geological Survey as serpentine, peridotite, and pyroxenite. The surrounding rocks have been altered locally to form talc schists, and in some of them there seems to have been further alteration due to contact metamorphism by the feldspar masses, as suggested by an unusual abundance of pyrite near the pegmatite and by the development there of narrow zones of fibrous serpentine (asbestos). These pegmatite masses appear to be entirely free from quartz, and their feldspar, so far as observed, is all of the soda variety (albite). Mica and other injurious minerals are rare or entirely absent.

The location of these quarries on the valley slope facilitates the handling of the material, which is carried down by chutes to the flats near the railroad and the river. The quantity of material is probably not sufficient to warrant mining for feldspar alone, but the feldspar forms an important adjunct in the quarrying of talc.

Rock Springs quarry.-In the spring of 1907 a small quarry was opened by the Verona Mining Company, of Trenton, N. J., about $3 \frac{1}{2}$ miles northeast of Conowingo. The material here is almost exactly similar in character and mode of occurrence to that just described from Bald Friar, and occurs within the same belt of basic rocks. 
(serpentine, pyroxenite, etc.). Talc is also obtained at this quarry. The spar is hauled by team 3 miles to Conowingo, from which it is shipped by rail. Feldspar has been quarried in the past at other points in the vicinity of Rock Springs and along Octoraro Creek.

\section{VIRGINIA.}

The following information in regard to the feldspar deposits of Virginia is taken from a report by Thomas L. Watson. ${ }^{a}$ The writer has not visited this district.

Pegmatite dikes containing feldspar as an important constituent are widely distributed through the Virginia area of crystalline rocks east of the Blue Ridge, hardly a county within the Piedmont area being without them. Notwithstanding their abundance and the fact that many of them contain commercially valuable feldspar, the attempts to mine this mineral have been comparatively few, and the production is as yet small. The principal area in which feldspar has been mined is in Amelia County, in the vicinity of Amelia Court House, where the mineral has been obtained as an accessory in the mining of mica. Mining of feldspar in an extensive pegmatite mass was recently begun on Otter River, about 3 miles southeast of Bells in Bedford County, by the Blue Ridge Kaolin Company, the product being shipped to East Liverpool, Ohio, for pottery purposes. A third quarry recently opened is located near Prospect, in Prince Edward County. In the past some feldspar was quarried near Jetersville, 8 miles southwest from Amelia Court-House, and ground for pottery purposes in a mill located at the mine.

The mines of the Amelia Court House district all occur within a distance of 2 miles or so northeast of Amelia, a station on the Southern Railway. Mining for mica in the district was first done about 1873 and has continued intermittently ever since, though of recent years only one property, the Pinchback mine, has been operated. The work has all been from open pits, the deepest of which probably does not exceed 100 feet. The principal rock of the district is a finely foliated, dark, fine-grained biotite gneiss, which may be either of igneous or of sedimentary origin. The pegmatite dikes intrude this gneiss and show feldspar, mica, and quartz as their principal minerals, the proportions among these three varying greatly. Some show dominant feldspar and mica with very little quartz, while others show dominant quartz and mica with little or no feldspar. The feldspar of these dikes includes the potash varieties, orthoclase and microcline, and the soda variety, albite.

In addition to the three principal minerals, a large number of rare minerals have been noted in the Amelia County pegmatites. These are microlite, fluorite, columbite, helvite, monazite, alunite, garnet, apatite, beryl, tourmaline, and zircon.

\footnotetext{
$a$ Watson, T. L., Mineral resources of Virginia, Virginia-Jamestown Expos. Com., 1907, pp. 276-284.
} 
The rocks are everywhere weathered to a considerable depth; outcrops are rare and many of the old openings are now partly caved in. As nearly as can be determined the larger pegmatite dikes will measure more than 50 feet across.

The Pinchback mine is the only mine which has recently been operated in this immediate district for feldspar, and is located about 2 miles north of Amelia Court House. It was first worked about eighteen years ago, and half a dozen or more openings have been made. The most recent one, opened in the spring of 1906 , has been worked to a depth of 28 feet. As exposed in this opening the dike is about 40 feet wide and is composed of white feldspar, white quartz, darkcolored mica, and an occasional crystal of beryl. Much of the feldspar is decomposed to a high-grade kaolin, which is mined and shipped. The remaining feldspar, which is only partly decomposed, slakes rapidly on exposure to the air. It is all saved and shipped to Trenton, N. J., where it is used in pottery manufacture. This quarry also produces both sheet and scrap mica; the largest mica sheets obtainable measure about 12 by 14 inches after trimming.

\section{MINNESOTA.}

A considerable quantity of lime-soda feldspar or plagioclase, varying in composition from labradorite to bytownite, is quarried in Lake County and ground at Duluth by two firms. The material is used mainly for abrasive purposes, filter beds, etc., although a small quantity is used in enamel ware.

\section{WISCONSIN. $a$}

The feldspar deposits of Wisconsin are still undeveloped. Pegmatite deposits containing feldspar are found in the town of Stettin, Marathon County, about 5 miles northwest of Wausau. They occur as pegmatite dikes cutting granite (quartz syenite), and are very abundant over an area 5 or 6 square miles in extent in the central part of this township. The dikes vary in width from 1 foot to 20 feet, and are said to be so abundant locally as to be nearly equal in quantity to the masses of granite lying between them. The principal constituents of the pegmatite dikes are feldspar and quartz, with subordinate quantities of white mica (muscovite) and of the iron-bearing minerals black mica (biotite), hornblende, pyroxene, and other minerals. Most of the feldspar is a fine-grained (microperthitic) intergrowth of potash feldspar and soda feldspar, and contains soda in nearly as large proportion as potash. It is therefore intermediate in composition between most of the so-called "hard" or potash feldspars mined in Canada and the eastern United

$a$ For a more detailed description of these deposits see Bull. Wisconsin Geol. and Nat. Hist. Survey No. 16, 1907, pp. 275-331, by Samuel Weidman. 
States, and the typical "soft" or soda feldspars, such as are mined in Chester County, Pa. The crystals of pure feldspar range from about an inch to somewhat over a foot in diameter. The dikes are not so large as most of those worked in the Eastern States, but they may prove to be of commercial value if the iron-bearing minerals are not so abundant or so distributed as to injure much of the feldspar.

These deposits are situated about 7 miles by road from the railroad station at Wausau and about 5 miles by road from the railroad station at Marathon, and seem worthy of investigation for commercial development.

\section{TEXAS.}

A pegamite deposit at Baringer Hill, Llano County, Tex., containing feldspar of the best pottery grades has been studied by Frank L. Hess, of the United States Geological Survey. The following are the portions of his report ${ }^{a}$ of especial interest to the feldspar trade:

Baringer Hill is located about 100 miles northwest of Austin, Tex., on the west bank of Colorado River, near the western edge of the Burnet quadrangle of the United States Geological Survey maps. It is 12 miles north of Kingsland, its nearest railroad point, 16 miles west of Burnet, and 22 miles northeast of the town of Llano. It is a low mound rising above the flood plain of the Colorado, and formed by the resistance to erosion of a pegmatite dike intruded in a porphyritic granite.

Few if any other deposits in the world, and certainly no other in America, outside of the monazite localities, have yielded such amounts of the rare-earth metal minerals as Baringer Hill.

The hill is named for John Baringer, who discovered in it large amounts of gladolinite in 1887. * * * The property is now controlled by the Nernst Lamp Company, of Pittsburg, Pa., and is worked by that concern for yttria minerals. Since its acquirement by this company a considerable amount of work has been done on the deposit, consisting mostly of open cuts around the edge of the pegmatite, reaching a depth of 30 or 40 feet. A large block, 30 feet in height and more in diameter, consisting mostly of quartz, is left standing in the middle.

In general the "Llano region," in the heart of which Baringer Hill is located, is an island of pre-Cambrian rocks intruded by plutonics and surrounded by an irregular zone of Cambrian and other Paleozoics, including some that are possibly Devonian and some Carboniferous rocks. The inner portion includes parts of Burnet, Llano, and Mason counties, and is situated at almost the geographic center of Texas. * * * The plutonic rocks are granitoid, of many textures, and differ considerably in composition. Large areas are composed of the rather coarse red granite, the principal outcrops of which occur near Marble Falls and from which the state capitol of Texas was built. Peculiar dikes of a chocolate-brown granite near Llano contain blue quartz. $b$ Other dikes containing this blue quartz are of a reddish color. In many localities the granite is very porphyritic, containing feldspars from 1 inch to 2 inches in longer diameter. There are also gray and fine-grained red granites, and in some places they have taken a gneissoid form. The granites are, at least in part, intrusive in crystalline schists and gneisses of uncertain origin, which are here and there graphitic

$a$ Hess, Frank L., Minerals of the rare-earth metals at Baringer Hill, Llano County, Tex., Bull. U. S. Geol. Survey No. 340, 1907, pp. 286-294.

$b$ Described by Joseph P. Iddings, Quartz-feldspar porphyry (graniphyro-liparose-alaskose) from Llano, Tex.: Jour. Geol., vol. 12, 1904, pp. 225-331. 
and contain interbedded strata of crystalline limestone. There are some later dikes of diabasic character, which are comparatively fresh. Southwest of Llano are areas of serpentine and other basic rocks.

In many places the granites are cut by pegmatite dikes, ranging in width from a few inches to 60 feet, which show a much greater percentage of quartz than of feldspar and other constituents, and afford beautiful illustrations of the most acidic phase of pegmatites. In a 6 -inch dike there may be but a few feldspar crystals from 1 inch to 3 inches long fringing the edges of the dike; in other dikes, or in other portions of the same dike, gradations from pure quartz to almost pure feldspar may be observed.

Baringer Hill is formed by such a dike on a huge scale. It is a small mound which, before mining was begun, rose perhaps 40 feet above a surrounding flat, was about 100 feet wide, and from 200 to 250 feet long. Its longer axis runs east and west and is nearly at right angles to the course of the Colorado River at this point. The country rock is a coarse porphyritic granite with feldspar phenocrysts about 1 inch long. This granite seems to weather and erode rather easily, and the river has cut a flood plain perhaps one-fourth of a mile wide at this point, while the dike, owing to its greater hardness and freshness, has better withstood the erosion.

The pegmatite, an unsymmetrical body with irregular walls, is intruded into the granite in what seems to be a pipe or short dike. At the edges of the intrusion is a graphic granite of peculiar beauty and definite structure, being more like the textbook illustrations than the usual graphic granite found in the field. The altered band is from 1 foot to 5 or 6 feet thick, and apparently surrounds the pegmatite. No segregation of the feldspar or quartz in particular parts of the dike can be noted, except that the feldspar may possibly be more inclined to occupy the sides of the intrusion. As far as shown it occupies most of the western and southern sides, and the quartz occupies the center and much of the eastern side.

One quartz mass is more than 40 feet across. The quartz has distinct white bands, from one-eighth to one-half inch wide, which seem to be due to a movement akin to flowage and are similar to those found in many pegmatitic masses in other portions of the country. The white banding is due to small liquid inclusions, many of them containing bubbles which either do not move from change of inclination of the fragment containing them or do so but slowly. *** At one place a vug was found large enough for a man to enter, lined with "smoky" quartz crystals reaching 1,000 pounds or more in weight. This would seem to indicate that the pegmatite had been intruded in a pasty or semifluid condition and that the vugs represent spaces occupied by segregated water that was squeezed from the magma as the minerals took their final solidified form.

The feldspar is an intergrowth of microcline and albite, of a brownish flesh color, beautifully fresh, and occurs (1) in large masses reaching over 30 feet in diameter, and (2) in huge crystals, many of which, though they rarely show terminal planes, have one or more sharply defined edges, especially where partially surrounded by quartz. An edge 34 inches long was measured on one crystal thus embedded. A smaller crystal was seen which was about a foot long, weighed 20 pounds, and showed fine termina. tions and twinning planes.

A large amount of feldspar has been mined and thrown on the dump, and it is possible that in time the dump material may be utilized, either for its potassium content as a fertilizer, or for pottery making.

Large crystals of fluorspar, measuring a foot along the edge, occur in the quartz, but this mineral does not form any considerable percentage of the mass. The fluorspar ranges from almost colorless to violet so dark that it is practically opaque. Where found alone in the quartz it was, so far as observed, of lighter color than where found with dark-colored minerals. Mr. Hidden informed the writer that it sometimes becomes luminous at the temperature of a living room. 
Ilmenite occurs in radiating bunches of sheets or blades ranging from 1 inch to 10 or 11 inches in width and from one-sixteenth to one-fourth of an inch in thickness. In cross section the ilmenite looks like the ribs of a fan, with the outer ends from onefourth to three-fourths of an inch apart. Similar aggregations take different angles, and numbers of such groups are found lying close together. With them occurs biotite mica in like bunches, the sheets of which are said to reach 3 feet in width by an inch in thickness. * * * Small flakes of lithia mica reaching half an inch in diameter are found, generally along cracks in the quartz. No muscovite was seen, but it is said to be found occasionally. Compared with the mass the total amount of mica is very small.

Present commercial interest in the dike centers in the accessory minerals, particularly in the rare-earth metal minerals, which, as stated, probably have never been found at any other place in masses and quantities so large as at this locality. So far the excavations are comparatively shallow, and the minerals found are more or less weathered; many show their crystalline form, but owing to alteration the crystals are now imperfect.

The accessory minerals include allanite, autunite, chalcopyrite, cyrtolite, fergusonite, gadolinite, gummite, hematite, lantleanite, magnetite, molybdenite, nivenite, pyrite, polycrase, powellite, rowlandite, rutile, sphalerite, tengerite, thorogummite, and yttrialite.

It is interesting to note that among the numerous minerals in this dike no tourmaline, zircon, beryl, monazite, cassiterite, garnet, or tungsten minerals have been found. Cassiterite has been reported from the neighborhood, but its occurrence is extremely doubtful.

With the exception of the alteration products and probably of the lithia mica, which, as noted, occurs along cracks in the quartz, all the minerals are believed to be original constituents of the dike.

16779-Bull. $420-10-6$ 



\section{INDEX.}

A. Page.

Albite, character of...................... $\quad 7-9$

Amelia County, Va., feldspar deposits in.... $\quad 77$

American Feldspar and Mining Co., quarry of $\quad 57$

Analyses of feldspar, tables of................

Andesine, character of.

Andrews quarry, description of............. 50-51

Androscoggin County, Me., feldspar deposits

in ......................... 23-27

Anorthite, character of ................. 7-9

Apatite, Mount, Maine, feldspar deposits at. 23-26

Ararat, Mount, quarries, description of ...... 34-36

Auburn, Me., feldspar deposits at.......... 23-26

feldspar deposits at, feldspar of, analysis of. 24,25

Avondale, Pa., quarry near................ 65

\section{B.}

Baker, Pa., quarry at.....................

Baker quarry, description of................

Bald Friar quarries, description of ...........

Baltimore County, Md. feldspar deposits at. 72-75

Baringer Hill, Texas, feldspar deposits at.... 79-81

Barrett Manufacturing Co., quarry of........ 55

Batchellerville quarry, description of....... 58-59

Bedford, N. Y., feldspar deposits at.......... 60-63

Bedford County, Va., feldspar deposits in.... 77

Berry, A. R., quarry of..................... 26-27

Beryl, character of...................... 12

Biotite, character of . ...................... 11-12

Blandford Quarries Co., quarries of......... 41

Brandywine Summit Kaolin and Feldspar Co., mill of. 71 quarry of.

Bridgeport Wood Finishing Co., mill of...... 62 quarry of............................ 53

Brown quarries, description of............. 75

Bytownite, character of................... 7

\section{C.}

Cathance, Me., mill at................... 39-40 Cecil County, Md., feldspar deposits in..... 76-77 Chatham, Conn., feldspar deposits at........ 47 Chatham quarry, description of............. 65-66 Chelsea, Pa., quarry at.................. 72 Chester County, $\mathrm{Pa}$., feldspar deposits in.... 64-70 Chester Heights, quarries at................ 71-72 Claspka Mining Co., quarries of............ 56, 58 Color of feldspars, range of................. 6,7 Concord, Pa., feldspar deposits at........... 70-72 Connecticut, feldspar deposits in.......... 15, 41-54 feldspar deposits in, distribution of...... 41-42 feldspar of, prices of ................ 21 production of .................. 22 See also particular counties. Conowingo, Md., quarries near.
Consolidated Feldspar Co.'s quarry, description of...................... 49-50

Cooperation, work done under.............. 5

Corinth, N. Y., feldspar deposits at........ 57-58

Corinth Feldspar Co., quarry of............ 57

Crown Point, N. Y., feldspar deposits at..... 54-55

Crown Point Feldspar Co., quarry of....... 54

Crystallography of feldspars, discussion of ... 6,7

\section{D.}

Deland Mining and Milling Co., quarry of... 76 Delaware County, Pa., feldspar deposits in .. 70-72 Dibble Mountain, New York, feldspar deposits at.

\section{E.}

East Glastonbury quarry, description of..... 43-44 Edgecomb, Me., feldspar deposits at........ 27-28 Edinburg, N. Y., feldspar deposits at........ 58-59 Elam, Pa., quarry at.................... 70 Embreeville quarry, description of......... 67 Emery wheels, feldspar for............... 19 Essex County, N. Y., feldspar deposits in.... 54-56 Eureka Mining and Operating Co., quarries of............ $42,45,47,51-53,65,72$

Eureka quarry, Conn., description of........ 72 Eureka quarry, Md., description of......... 51-53

F.

Fagan quarry, description of............. 74-75

Fertilizer, use of feldspar for............... 20

Feldspar, analyses of....................... 9

chemistry of..................... 5

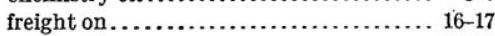

grades of ............................ 21-22

markets for........................... 16-18

milling methods with ................. 18-19

origin of ............................ 10

physical properties of................ $5-9$

prices of ............................ 21-22

production of....................... 22-23

uses of ........................ 16,18,19-20

Feldspar deposits, descriptions of.......... 23-81 descriptions of. See also particular States.

distribution of $\ldots \ldots \ldots \ldots \ldots \ldots \ldots \ldots \ldots, 10$

mineral composition of ............... 9, 11-15

injurious constituents of............... 17

mining of ........................... 15-16

value of ............................. 16-18

Fisher's quarry, description of................ $36-37$

French quarry, description of............. 74

Frost quarry, description of............... $75-76$

Fulton County, N. Y., feldspar deposits in.. 56-57 
G.

Page.

Garnet, character of ..................... 12-13

Gems, occurrence of ....................... 24, 27

Geology of deposits, outline of ............ 10-11

Georgetown, Me., feldspar deposits at...... 31-33

Gerry, J. A., quarry of .................... 28

Glass, use of feldspar in................ 19-20

Glastonbury, Conn., feldspar deposits at.... 42-46

Glaze, use of feldspar for ................. 19

Golding's quarry, description of............ 31-33

feldspar from, analysis of .............. 31

Golding Sons Co., quarries of.............. 31, 75

Granite, Md., quarries near................. 72

Granite-pegmatite, feldspars in............ 10

minerals in .......................... 11-15

physical characters...................... 13

Graphic granite, analyses of ............... 14

character of............................ 13-15

feldspar and quartz in ................. 15

Guilford and Waltersville Granite Co., quarry

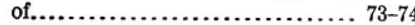

H.

Haddam, Conn., feldspar deposits at........ 48-49 Haddam Neck quarry, description of ........ 48-49 Hartford County, Conn., feldspar deposits in. 42-46 Hebron, Me., feldspar deposits at............ 28-30 Hess, F.L., on feldspar deposits in Texas ... 79-81 Hibbs quarry, description of................ 28-29 Hobby quarries, description of............... 63 Hopkins, T. C., on Pennsylvania quarries 64, $67,71-72$

Howard County, Md., feldspar deposits in.... 75-76 Howe, L. W., mill of, description of ......... 46 quarry of, description of............. 41, 45-46

\section{K.}

Keystone Feldspar Co., quarry of........... 68-69 Keystone quarry, description of............ 65-69 Kinkle's Sons, mill of, description of ......... 62-63 quarries of, description of........... $60-62,63$

\section{L.}

Labradorite, character of.

Lime-soda feldspar, chareter of ..... 78

Lincoln County, Me., feldspar deposits in.... 27-28

Llano County, Tex., feldspar deposits in..... $79-81$

London Grove, Pa., feldspar deposits at..... 64-66

\section{M.}

Maine, cooperation of.. feldspar deposits in ................... 15,23-40 feldspar of, prices of production of. See also particular counties.

Maine Feldspar Co., mill of...... 25, 26, 27, 38, 39-40 quarry of........................... 38,40

Marathon County, Wis., feldspar deposits in. 78-79 Maryland, feldspar deposits in...... 10,15-16,72-77 feldspar deposits in, feldspar of, prices of. 21 feldspar of, production of............ 22 See also particular counties.

Massachusetts, feldspar deposits in.......... 41

Melting point of feldspars, range of........... $6 ; 8$

Meredith quarry, description of.............. 67

Microcline, character of .
Page.

Middlesex County, Conn., feldspar deposits in. 47-53 Middletown, Conn., feldspar deposits at... 49-50 Middletown, Pa., feldspar deposits at........ 72 Milling. methods of........................ 18-19 Mills quarry, description of.................. 29-30 Mineral composition of feldspars, table of.... 9 Mining, methods of......................... 15-16 Minnesota, feldspar deposits in............. 78 Minot, Me., feldspar deposits in.............. 26 Mount Marie Mining Co., quarry of.......... $\quad 29$ Muscovite, character of..................... 11

N.

New Garden, Pa., feldspar deposits at....... 66 New Haven County, Conn., feldspar deposits in......................... 53-54

New Jersey, feldspar of, prices of............. 21 feldspar of, production of............... 22

Newlin, Pa., feldspar deposits at............. 67

New York, feldspar deposits in.......... 15, 54-63 feldspar deposits in, feldspar of.......... 6 feldspar of, prices of.................. 21 production of.................. 22

North Castle, N. Y., feldspar deposits at..... 63

Number Four Hills, feldspar deposits at.... 29

O.

Oligoclase, character of................... 7

Ontario, feldspars of ....................... 6

Orthoclase, character of.................... $\quad 5-6$

Oxford County, Me., feldspar deposits in.... 28-30

P.

Parlet \& Cavey quarry, description of.......

73

Pegmatite. See Granite-pegmatite.

Pennsylvania, feldspar deposits in.. 10,15-16,63-72 feldspar deposits in, feldspar of, prices of. $\quad 21$ feldspar of, production of............ 22 See also particular counties.

mills in............................ 64

Pennsylvania Feldspar Co., quarry of......... 66 Pennsylvania Marble and Granite Co., quarry of ..................... 64-65

Pinchback mine, description of................ 78

Plagioclase, character of .................... $\quad 7-9$

Poland, Me., feldspar deposits in........... 26-27

Portland, Conn., feldspar deposits at. ....... 50-53

Potash salts, manufacture of................ 20

Potash-soda feldspars, characters of............ $5-6$

Pottery, feldspar for......................... 19

Poultry grit, feldspar for......................

Prices, range of .......................... 21-22

Prince Edward County,Va., feldspar deposits in........................... 77

Production, statistics of ..................... 22-23

Q.

Quartz, character of..................... 11

R.

Riverside quarry, description of............ 50

Robinson, W. S., quarry of .................. ${ }_{28}^{5}$

Rock Springs quarry, description of......... 76-77 $\mathrm{S}$.

Sagadahoc County, Me., feldspar deposits in. 31-41 Saratoga County, N. Y., feldspar deposits in. 57-59 
Page.

Sharpless, Pa., quarry at

Snow, L. T., quarry of

Soda-potash feldspars, characters of

Southford quarry, description of

Sparvetta Mining Co., quarry of

Sparvetta quarry, description of

Stettin, Wis., feldspar deposits at

Sylmar; Md., quarry near .

$\mathrm{T}$.

Teeth, artificial, use of feldspar for

Texas, feldspar deposits in

Thompson quarry, description of.

Ticondero quar 55

Ticonderoga Feldspar Co., quarry of.

Topsham, feldspar deposits in...

Toughkenamon mill, description of...

Toughkenamon quarry, description of

Tourmaline, character of.

Trenton Flint and Spar Co., quarry of

Turner, E. Y., quarries of.

U.

Unionville quarries, description of.

Uses of feldspar, description of.
V.

Page.

Verona Mining Co., quarry of................ 76

Virginia, feldspar deposits in............. $77-78$ feldspar deposits in, feldspar of, produc-

tion of.........................

See also particular counties.

W.

Watson, T. L., on feldspar deposits in Virginia...................... 77-78

Weidman, Samuel, on feldspar deposits in Wisconsin.................... 78

West Caln, Pa., feldspar deposits at......... 67 Westchester County, N. Y., feldspar deposits in........................ 54,60-63 West Nottingham, Pa., feldspar deposits at.. 68-70 White Rocks, Conn., feldspar deposits at... 49, 50

Wiarda, J. C., mill of, description of......... 45

quarry of, description of................ 44-45

Willes, G. D., quarry, description of ....... 38-39

Willes, William, quarry, description of ...... 37-38

Wisconsin, feldspar deposits in............ 78-79

Woodstock, Md., quarries near............. 73,75 



Lithomount

Pamphlet

Binder

Gaylord Bros. Inc.

Makers

Syracuse, N. Y.

PAT. JAN 21, 1908 
